\title{
The Arbitration Fairness Index: Using a Public Rating System to Skirt the Legal Logjam and Promote Fairer and More Effective Arbitration of Employment and Consumer Disputes
}

\author{
Thomas J. Stipanowich*
}

\section{INTRODUCTION: THE LEgAL LOGJAM AND THE NEED FOR A Practical, EFFECTIVE NON-LEGAL ALTERNATIVE}

"I can't help feeling that there's been a big mistake somehow."1

Reflecting on the recent activities of our national government, one may be tempted to echo the words of Thomas Jefferson Smith, the naïve and idealistic young senator in Frank Capra's classic film, Mr. Smith Goes to Washington. Such reflections are particularly apropos when it comes to the development of American arbitration law and the current state of binding ("mandatory") arbitration agreements in consumer and employment contracts. Consider the following facts:

* William H. Webster Chair in Dispute Resolution, Professor of Law, Pepperdine University School of Law; Academic Director, Straus Institute for Dispute Resolution. The author wishes to extend thanks to the University of Kansas School of Law and the University of Kansas Law Review, which sponsored this symposium, Perspectives on the Current State of Arbitration Law, which helped inspire this "end run" around the legal logjam. Although the opinions reflected herein are the author's own, he is also indebted to a number of colleagues for useful suggestions and criticisms, including Lisa Blomgren Bingham, Chris Drahozal, Sally Greenberg, Paul Kirgis, Dave Lipsky, Jack McCrory, Amy Schmitz, Nancy Welsh, and to other members of the National Roundtable on Consumer and Employment Dispute Resolution, which met at Pepperdine on Feb. 2-4, 2012, and established a working group that will focus on this concept. See Nat'l Roundtable on Consumer \& Emp’t Dispute Resolution, Consumer Arbitration Roundtable Summary Report, AM. BAR Ass'N (Apr. 17, 2012), http://www.consumerfinance.gov/pressreleases/consumer-financial-protectionbureau-launches-public-inquiry-into-arbitration-clauses/. Thanks also to the American Bar Association Section of Dispute Resolution, which gave me the opportunity to co-facilitate discussions of the Consumer Arbitration Study Group in January, 2010, an important precursor to the Roundtable. Special thanks are due to Gina McCoy, Research Librarian at Pepperdine University School of Law, and Shawn Davis, J.D., Masters in Dispute Resolution 2011, Pepperdine University School of Law, for their exceptional efforts in helping complete this article under extreme time pressures, as well as Sara Rosenblit and Maxfield Marquardt, J.D. candidates 2012, Pepperdine University School of Law, for additional research assistance.

1. Mr. Smith Goes to Washington (Columbia Pictures 1939). 
1. Thanks to a series of increasingly expansive interpretations by the U.S. Supreme Court, a federal statute designed to promote private, choice-based alternatives to trial is now the vehicle for enforcing dense boilerplate language in mass-produced contracts to which "assent" is often fictional in all but the most formal sense. ${ }^{2}$

2. State statutes and state common law surrounding enforceability of agreements are preempted by federal law involving interstate commerce, which means that legislatures and courts have very few tools to regulate arbitration agreements in adhesion contracts.

3. Contract defenses are the primary means by which courts regulate arbitration. ${ }^{4}$ The doctrine of unconscionability is judges' primary tool for policing unfairness in arbitration agreements. ${ }^{5}$ The Supreme Court recently declared dramatic new limitations on judicial use of unconscionability defenses with respect to arbitration agreements. ${ }^{6}$

4. Limitations on unconscionability defenses were reinforced by the Court's strong support of "delegation" provisions that take away judicial oversight of arbitration agreements and give it to the arbitrators. will deal with issues of fairness, not only under the whole consumer or employment contract, but also within the arbitration agreement. ${ }^{8}$ Rent-A-Center West, Inc. v. Jackson

2. See Thomas J. Stipanowich, The Third Arbitration Trilogy: Stolt-Nielsen, Rent-A-Center, Concepcion and the Future of American Arbitration, 22 AM. REv. InT'L ARB. 323, 328-30, 367-70, 380-86 (2012) (discussing the Court's interpretation of the Federal Arbitration Act (FAA)).

3. See id. at 328-30 (providing background on the FAA and its preemptive effects).

4. Amy J. Schmitz, Legislating in the Light: Considering Empirical Data in Crafting Arbitration Reforms, 15 HARV. NEGOT. L. ReV. 115, 123 (2010).

5. See id. at 124-26 (providing examples of courts that did not enforce unconscionable arbitration clauses); infra text accompanying note 174 .

6. See AT\&T Mobility LLC v. Concepcion, 131 S. Ct. 1740, 1747-50 (2011) (use of unconscionability doctrine "stand[s] as an obstacle to the accomplishment of the [FAA's] objectives," which is "to ensure the enforcement of arbitration agreements according to their terms so as to facilitate informal, streamlined proceedings" (citing Geier v. Am. Honda Motor Co., 529 U.S. 861, 872 (2000))); Stipanowich, supra note 2, at 380-87 (discussing use of unconscionability defenses to police the substantive terms of arbitration agreements in the wake of Concepcion).

7. See Rent-A-Ctr., W., Inc. v. Jackson, 130 S. Ct. 2772, 2777-78 (2010) (discussing the effects and enforceability of a delegation provision); see also Stipanowich, supra note 2, at 364-70 (emphasizing the great impact of the Rent-A-Center decision).

8. See Rent-A-Ctr., $130 \mathrm{~S}$. Ct. at 2778-79 (finding that unless the delegation provision specifically was challenged, it was enforceable, "leaving any challenge to the validity of the [arbitration] [a]greement as a whole for the arbitrator"); Stipanowich, supra note 2, at 368 (reasoning that this approach significantly restricts the judicial policing function and places greater responsibilities on the shoulders of private arbitrators). 
has dramatically enhanced the possibility that arbitration will be "a hermetically sealed black box."”

5. Practically speaking, the only time consumers or employees may be able to raise concerns about procedural issues in arbitration is at the conclusion of the arbitration process with a motion to vacate. ${ }^{10}$ This, of course, creates a tremendous barrier for individuals. ${ }^{11}$ The recent Supreme Court decision in Hall Street Associates v. Mattel has reinforced limitations on judicial review.

6. The Court has also made arbitration agreements a vehicle for undercutting consumers and employees' ability to take collective action through class arbitrations. ${ }^{13}$

7. In our broadly polarized Congress, there seems to be little room for nuanced responses to these realities. Most Democratic proposals are founded on the belief that binding arbitration under pre-dispute clauses is inherently unfair and should be outlawed in consumer and employment transactions. ${ }^{14}$ Currently, Congress is considering different versions of a proposed Arbitration Fairness Act that would effectively outlaw pre-dispute arbitration agreements in consumer, employment, and franchise agreements. It would also outlaw arbitration provisions in brokerage agreements that are already subject to oversight and regulation by the Securities and Exchange Commission (SEC). ${ }^{9}$ Republicans have sought to undo consumer legislation aimed at, among other things, closer review of the operation of arbitration under consumer financial services contracts and investor/broker contracts. ${ }^{16}$

9. Stipanowich, supra note 2, at 370 .

10. See, e.g., Stolt-Nielsen, S.A. v. AnimalFeeds Int'l Corp., 130 S. Ct. 1758, 1766 (2010) (discussing the district court and Second Circuit decisions on whether defendants' motion to vacate should be granted).

11. See Stipanowich, supra note 2, at 367-70 (discussing the effect delegation provisions have on a court's ability to protect weaker parties).

12. See Hall St. Assocs. v. Mattel, Inc., 552 U.S. 576, 590 (2008) (holding the grounds for judicial review of arbitration awards set forth in sections ten and eleven of the FAA, 9 U.S.C. §§ 1011 (2006), are the exclusive sources of judicial review under that statute).

13. See AT\&T Mobility LLC v. Concepcion, 131 S. Ct. 1740, 1755-56 (2011) (holding that the FAA preempted a California state law thus enforcing class action waivers); see also Stipanowich, supra note 2, at 375-76 (evaluating Concepcion's impact on class actions).

14. See Stipanowich, supra note 2, at 396-404 (reviewing legislation).

15. See generally Thomas J. Stipanowich, Arbitration: The "New Litigation", 2010 U. ILL. L. REV. 1, 40-49 (discussing these initiatives and their "spillover" into commercial (B2B) arbitration).

16. See, e.g., Laura Meckler \& Victoria McGrane, Both Parties Seek Edge as Nominee Is 
Meanwhile, binding arbitration agreements continue to be very widely used in consumer contracts ${ }^{17}$ and individual employment contracts. ${ }^{18}$ There is strong evidence that consumers do not read the fine print of arbitration agreements, ${ }^{19}$ and that they are predisposed to accept contracts that contain boilerplate arbitration terms for reasons that have nothing to do with their perceptions about the fairness or effectiveness of arbitration. $^{20}$

Because fundamental fairness hinges on many different characteristics of dispute resolution systems, arbitration programs may or may not provide an appropriate substitute for civil litigation. ${ }^{21}$ While, as discussed below, it is entirely possible for binding arbitration to effectively serve this role, there are also many ways in which private adjudication programs may fall short of public expectations about civil justice.

First of all, people who find themselves in binding arbitration programs may have very little information about the rules and procedures under which they are expected to operate. ${ }^{22}$ They may have no idea about how to obtain a suitable arbitrator, the kind of hearing that may

Blocked, WALL ST. J., Dec. 9, 2011 (discussing Republican attempts to rein in Dodd-Frank).

17. See Stipanowich, supra note 2, at 328 n.15 (citing FED. RESERVE BANK OF BostON, THE Survey of CONSUMER PAYMENT CHOICE (Jan. 2010); URBAN Justice CENTER, DebT Weight: THE CONSUMER CRISIS IN NEW YORK CITY AND ITS IMPACT ON THE WORKING POOR 3 (Oct. 2007), available at http://www.urbanjustice.org/pdf/publications/CDP_Debt_Weight.pdf (noting that binding arbitration agreements are widely used in credit card agreements and have also been utilized in debt collection cases); Alexander J.S. Colvin, Empirical Research on Employment Arbitration: Clarity Amidst the Sound and Fury?, EMPL. RTS. \& EMPLOY. POL’Y J. 405, 411 (2007)).

18. See id. (observing that arbitration agreements in individual employment contracts "may affect as many as [fifteen to twenty percent] of employees" (citing Colvin, supra note 17, at 411)).

19. See Schmitz, supra note 4, at 134-36 (providing statistics from consumer studies on contract terms).

20. See id. at 130-33 (noting that some of those reasons may include fear of "raising thorny issues," consumer's need for products, and unfair bargaining power); FED. TRADE COMM'N, REPAIRING A BROKEN SYSTEM: PROTECTING CONSUMERS IN DEBT COLLECTION LiTIGATION AND ARBITRATION 41-43 (2010) [hereinafter FTC STUDY] (stating that FTC roundtable participants suggested (1) that consumers do not understand arbitration and its implications and may not be aware of arbitration clauses in their contracts and (2) that consumers may not negotiate over arbitration because they may believe they have no alternatives among companies in an industry or because "time is of the essence" in purchasing goods or services).

21. See Developments in the Law-Access to Courts: III. Mandatory Arbitration Clauses: Proposals for Reform of Consumer-Defendant Arbitration, 122 HARV. L. REV. 1170, 1174-75 (2009) [hereinafter Developments in the Law] (examining two problems with consumer-defendant arbitration as bias "in favor of the repeat-player corporation" and disadvantage to "less-sophisticated consumer defendant[s]”).

22. See FTC STUDY, supra note 20, at 41-43 (discussing consumers' understanding of arbitration). 
occur, or the relief that may be obtained. Besides undermining the notion of true assent to arbitration, all of these uncertainties place them at a distinct disadvantage at the outset. There is, moreover, little, if any, evidence that companies promote or incentivize conscious choices regarding arbitration. ${ }^{23}$

Second, there are legitimate concerns about the provenance of the arbitration program and the independence of the administrative framework under which arbitration is conducted. ${ }^{24}$ The notion that justice may be fairly and effectively dispensed under the auspices of a private corporation whose legal rights are at issue should strike reasonable people as absurd. On various occasions, such programs have led a disapproving court to expose systemic bias or flaws in the programs' designs ${ }^{25}$ or administration. ${ }^{26}$ As exemplified by the muchpublicized National Arbitration Forum, ${ }^{27}$ even some apparently freestanding institutions that sponsor and administer arbitration programs may have real or perceived inherent conflicts of interest. ${ }^{28}$

Third, there are concerns about arbitrators, the individuals whose decisions - awards - are largely immune to judicial reversal for errors of law or fact and hence more ironclad than court judgments or jury verdicts. ${ }^{29}$ Parties may reasonably ask, is my decision maker subject to pro-corporate or pro-employer bias? ${ }^{30}$ Am I disadvantaged because the

23. See id. at 41-46 (discussing meaningful consumer choices and how consumers rarely exercise their options).

24. See id. at 51-54 (discussing perceptions and concerns regarding "forum bias" in debt collection arbitration).

25. See, e.g., Hooters of Am., Inc. v. Phillips, 173 F.3d 933, 940 (4th Cir. 1999) (describing employer-developed arbitration rules and procedures as a "sham").

26. See, e.g., Engalla v. Permanente Med. Grp., Inc., 938 P.2d 903, 922 (Cal. 1997) (holding that the health plan fraudulently misrepresented speed of its arbitrator selection process and engaged in dilatory conduct).

27. See FTC STUDY, supra note 20, at 39-40 (describing the 2009 suit filed by Minnesota Attorney General against the National Arbitration Forum (NAF), "then the leading debt collection arbitration forum," alleging "consumer fraud, deceptive trade practices, and false advertising," and subsequent settlement under which NAF agreed to cease arbitration of consumer debt collection disputes).

28. To quote an FTC report: "NAF purportedly held itself out as an impartial provider of dispute resolution while actually having financial ties to key members of the debt collection industry through a series of complex and purposefully hidden affiliations." Id. at 39.

29. See ian R. Macneil, Richard E. Speidel \& Thomas J. Stipanowich, Federal ARbitration LaW: Agreements, AWARds, and Remedies under the FEderal ARbitration ACT $\S \S 38-42$ (1994) (discussing the procedures for and difficulty in vacating or overturning an arbitration award under the FAA).

30. See FTC STUDY, supra note 20, at 47-51 (discussing possible reasons for bias or perceived bias among arbitrators); Developments in the Law, supra note 21, at 1174 (discussing concerns over pro-corporate arbitrators) 
company is a repeat player in the system, ${ }^{31}$ my arbitrator cannot identify with $\mathrm{me},{ }^{32}$ or my arbitrator lacks the proper training and experience? ${ }^{33}$

Fourth, there are concerns about arbitration procedures-the rules that define and give shape to the process of arbitration. Especially in the absence of specified rules, either because no rules are specified in the agreement or because they cannot be obtained for review, parties to arbitration face many unanswered questions. How much will it cost me $?^{34}$ Will I receive adequate notice if a demand is filed against me ${ }^{35}$ May an attorney represent me? Can I obtain critical documents or testimony? What kind of a hearing am I entitled to and when and where will it be held? How long will it take to obtain relief? Can I bring a claim as part of a collective action by other consumers or employees? ${ }^{36}$ If not, does the bar to class-wide relief effectively "chill" the environment for my claim? ${ }^{37}$

Finally, there are concerns about the eventual outcome and the relief obtainable through arbitration. Parties are rightly worried about limitations on remedies, especially statutory remedies such as treble damages and attorney fees. ${ }^{38}$ They may also prefer to have an award that

31. See FTC STUDY, supra note 20, at 48-51 (discussing various perceptions and studies regarding "repeat player" bias); Developments in the Law, supra note 21, at 1174-75; see also Stipanowich, supra note 2, at 424-25 \& n.618.

32. See FTC STUDY, supra note 20, at 50 (discussing perceived need for balance and diversity in "rosters of arbitrators" maintained by arbitration forums for debt collection arbitration); see also Larry J. Pittman, Mandatory Arbitration: Due Process and Other Constitutional Concerns, 39 CAP. U. L. REV. 853, 862-65 (2011) (discussing need for diversity in arbitrator pool).

33. See, e.g., NAT'L CONSUmer Disputes Advisory COMm. \& AM. ARBitration Ass'N, Consumer Due Process Protocol, Principle 4, Reporter's Comments (1997), available at http://www.adr.org (search for "Consumer Due Process Protocol”) [hereinafter ConsuMER PROTOCOL] ("While ensuring the competence of Neutrals is always important, it is particularly 'critical in contexts where party choice over the process, program or neutral is limited' a reality of many Consumer ADR programs.” (citing SOC'Y OF PROF'LS IN DISP. RESOL. (SPIDR) COMMISSION ON QUALIFICATIONS, ENSURING COMPETENCE AND QUALITY IN DisPUTE RESOLUTION PRACTICE 5 (1994); SPIDR COMM’N ON QUALIFICATIONS, PRINCIPLES CONCERNING QUALIFICATIONS, PRINCIPLE 3 (1989))).

34. See FTC STUDY, supra note 20, at 60-62 (discussing concerns regarding costs of arbitration to consumers).

35. See id. at 54-59 (discussing concerns about lack of effective notice to consumer-debtors regarding filing of arbitration demand by creditors).

36. See Developments in the Law, supra note 21, at 1176 n.41; Theodore Eisenberg, Geoffrey P. Miller \& Emily Sherwin, Mandatory Arbitration for Customers but Not for Peers: A Study of Arbitration Clauses in Consumer and Non-Consumer Contracts, 92 JUDICATURE 118, 121 (2008) (noting that "[e]very consumer contract with a mandatory arbitration clause also included a waiver of the right to participate in class-wide arbitration”).

37. See Eisenberg, Miller \& Sherwin, supra note 36, at 121-23 (discussing variations in type and content of contracts including arbitration clauses that prohibit class-wide relief).

38. See Richard A. Bales \& Michelle Eviston, The Federal Arbitration Act Needs a Due 
spells out the disposition of various claims and controversies as well as the rationale underpinning the decision. ${ }^{39}$

What, one might ask, are we to do about this state of affairs? As previously stated, regulation through the application of legislatively or judicially decreed legal norms is now severely inhibited under the Federal Arbitration Act (FAA), ${ }^{40}$ and it is unclear what, if any, action may take place in Congress or in the Executive branch.

There is, however, an as-yet unexplored opportunity to address all of the foregoing concerns while accomplishing other goals. It can be readily implemented, and has the cardinal virtue of not being dependent on the actions of courts, legislatures, or agencies. It also does not depend strictly upon how the Supreme Court or other tribunals view the legal acceptability of corporate conduct, but appeals directly to different standards of the marketplace. It is, in short, a public rating system assessing the fairness of arbitration programs associated with contracts for consumer goods or services or individual employment contractswhat we call an "Arbitration Fairness Index."

The Arbitration Fairness Index would be an "independent, standardized, third-party assessment" 41 of arbitration clauses in specific corporate consumer contracts or individual employment agreements. Developed and implemented by a respected institution with broad-based input, perhaps coupled with highly visible ratings and rankings that hold up appropriate programs to public acclaim or shame, an Arbitration Fairness Index holds the promise of accomplishing numerous laudable goals:

1. To represent the first broad-based effort to examine and bring to light a heretofore largely invisible aspect of consumer contracting.

2. To serve as a forum for different interest groups to discuss fairness and effectiveness in adjudication without being distracted by attitudes toward contract law and policy.

Process Protocol, BANKING \& Fin. SERVICES POL'y ReP., July 2010, at 16-17 (proposing that “the FAA should be amended to provide explicitly that arbitration agreements cannot waive statutory remedies").

39. See FTC STUDY, supra note 20, at 62-64 (discussing concerns about lack of rationale supporting awards in debt collection arbitration and need for reasoned opinions).

40. See Stipanowich, supra note 2, at 328-30.

41. See Harold Furchtgott-Roth, Robert W. Hahn \& Anne Layne-Farrar, The Law and Economics of Regulating Ratings Firms, 3 J. COMP. L. \& ECON. 49, 87 (2007) (describing Underwriters Laboratories role as independent tester of product safety). 
3. To draw broad public attention to arbitration programs and their workings as well as key differences between programs.

4. To help acquaint and educate the public on class action waivers and other consumer or employee rights contract terms, and provide a basis for comparison among programs.

5. To provide a more dependable and useful source of information than reports that employ selective data in isolation. Instead of focusing on individual horror stories that may not be wholly representative of particular programs, the Index would comprehensively examine programs, and ratings would be based on many sources of information, including reports of personal experiences or statistics.

6. To offer a more fulsome and accurate picture of arbitration programs in practice and potentially create a more balanced and nuanced public perception of arbitration programs.

7. To put pressure on businesses to provide more information about their arbitration programs including rules and procedures, arbitration panels, administrative practices, and case statistics.

8. To shed additional light on the policies and practices of organizations providing arbitration services- "arbitration forum[s]" 42 or "provider organizations."

9. To provide incentives to businesses and business sectors to develop and maintain fair, effective programs and more carefully weigh the cost of that "extra bite of the apple."

10.To help push the envelope by promoting actual incentives for consumers or employees to choose arbitration.

11.To provide a potential foundation for the future efforts of courts, legislators, and other policymakers in ensuring the protection of individuals' rights and, where appropriate, promoting effective punishment and deterrence. ${ }^{44}$

42. See FTC STUDY, supra note 20, at 37 (employing nomenclature of "arbitration forum[s]").

43. See generally CPR-GEORgETOWN COMM'N ON ETHICS \& STANDARDS OF PRACTICE IN ADR, PRINCIPLES FOR ADR PROVIDER ORGANIZATIONS (2002), available at http://www.cpradr.org/ Portals/0/Resources/ADR\%20Tools/Tools/Principles\%20for\%20ADR\%20Provider\%20Organizatio ns.pdf [hereinafter PRINCIPLES FOR PROVIDER ORganizations] (employing nomenclature of "provider organization").

44. See Stipanowich, supra note 2, at 427-32 (discussing potential alternatives to the current 
The pervasive and important role of ratings and rankings in our society and the likely benefits of an Arbitration Fairness Index are discussed in Part II, along with a set of guidelines for developing and publishing ratings or rankings.

Part III explores several existing norms that could provide the foundation for an Index. These include positive legal standards such as revisions to the Uniform Arbitration Act and the California Ethics Standards, which are legally mandated disclosure requirements for arbitrators and arbitral institutions. ${ }^{45}$ Other norms include court decisions addressing fairness issues in arbitration under the FAA and state law. ${ }^{46}$ There are also due process standards developed by various groups in the 1990s and consumer and employment arbitration procedures incorporating and administered pursuant to these guidelines. ${ }^{47}$ In addition, there are procedures and practices developed under regulated arbitration between securities investors and brokers. ${ }^{48}$ There is a wide range of "community standards" - such as the Principles for ADR Provider Organizations-aimed solely at the largely overlooked organizations "behind the neutral" that provide dispute resolution services. ${ }^{49}$ There is, moreover, the very thoughtful exploration of issues and perceptions regarding debt collection litigation and arbitration articulated by the Federal Trade Commission (FTC). ${ }^{50}$ Currently, there are groundbreaking efforts exploring the potential for online dispute resolution (ODR). ${ }^{51}$ Finally, there is a growing body of empirical research exploring consumers and employees' experiences with and perceptions of arbitration processes. ${ }^{52}$

Part IV offers a possible template for an Arbitration Fairness Index that would grade consumer and employment programs on each of twenty-three elements. These elements are grouped under five general headings that correspond to key concerns about arbitration: (1) Meaningful Consent, Clarity, and Transparency; (2) Independent and

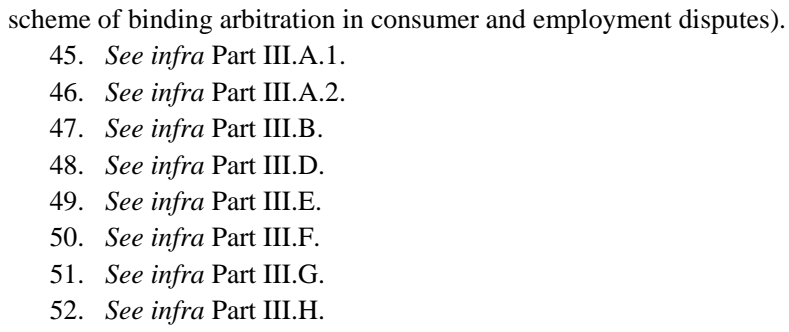


Balanced Administration; (3) Quality and Suitability of Arbitrators; (4) Fair Process; and (5) Fair Outcomes.

Part $\mathrm{V}$ examines other issues that must be addressed to effectively implement an Arbitration Fairness Index. While the publication of an Index promises to provide numerous benefits to the public, such a system also entails costs that someone must bear. To be meaningful and effective, a rating system must be perceived as thoughtfully and fairly conceived and administered by a trustworthy and respected body. ${ }^{53}$ The information that is fed into the rating process must be reliable, accurate, and fairly representative. ${ }^{54}$ Finally, ratings must be presented in visible, accessible, and useful formats in order to exert influence on the marketplace. ${ }^{55}$

\section{BACKGROUND: POTENTIAL BENEFITS OF AN ARBITRATION FAIRNESS INDEX}

\section{A. Living by the Numbers: Our Ratings-Driven Culture}

For better or worse, we live in a world driven by ratings and rankings, with rating firms operating in nearly every sector of our economy. ${ }^{56}$ We read Consumer Reports to assess the relative quality and characteristics of consumer goods ${ }^{57}$ and look for an Underwriters Laboratories seal as certification of product safety testing. ${ }^{58}$ We consult guides published by Michelin ${ }^{59}$ or Zagat ${ }^{60}$ before deciding where to eat. Grades from the Better Business Bureau give us a rough gauge of business quality and ethics. ${ }^{61}$ Students and their families scrutinize the

53. See infra Part V.A.

54. See infra Part V.B.

55. See infra Part V.C.

56. See Furchtgott-Roth, Hahn \& Layne-Farrar, supra note 41, at 84, 94 (listing various sources of ratings for different industries).

57. See id. at 94 (listing Consumer Reports as a source for financial industry ratings and rankings); Our Mission, CONSUMER REP., https://www.consumerreports.org/cro/aboutus/mission/ overview/index.htm (last visited Mar. 7, 2012).

58. See Furchtgott-Roth, Hahn \& Layne-Farrar, supra note 41, at 87 (noting that "[t]he product safety industry is dominated by Underwriters Laboratories”); About UL, UL, http://ul.com/global/ eng/pages/corporate/aboutul/ (last visited Mar. 7, 2012) (listing many statistics indicating the breadth and number of products certified by Underwriters Laboratories).

59. See Red Guides, Michelin, http://www.michelintravel.com/guides-cat/red-guides/ (last visited Mar. 7, 2012); see also Furchtgott-Roth, Hahn \& Layne-Farrar, supra note 41, at 82-83.

60. See Welcome to ZAGAT.com!, ZAGAT, http://www.zagat.com/ (last visited Mar. 7, 2012).

61. See Vision, Mission and Values, BetTER BUS. BUREAU, http://www.bbb.org/us/BBBMission/ (last visited Mar. 7, 2012). Even the organizations that provide rankings are not above 
rankings in U.S. News \& World Report to guide choices among undergraduate, business, law, and other professional schools. ${ }^{62}$ Concerned parents can check the Motion Picture Association of America ratings on movie content, ${ }^{63}$ while film attendance is spurred by the Academy of Motion Picture Arts \& Sciences' sign of approval-the Oscars ${ }^{64}$-and discouraged by the mirror-opposite, the Razzies, which hold up purportedly bad films to public scorn. ${ }^{65}$ Moody's, Standard \& Poor's (S\&P), and Fitch are touchstones for investors in bond markets, ${ }^{66}$ and recent S\&P downgrades of U.S. and European government debt have had a dramatic impact. ${ }^{67}$ Advertisers rely on Nielsen Media Research

being ranked themselves. A recent Consumer Reports article cautioned: "When viewing a BBB report, don't put a lot of credence in a high letter grade or in BBB accreditation. But do pay attention to a low grade; it could be a sign of real trouble.” Can You Trust the Better Business Bureau?, CONSUMER REP., Aug. 2011, at 10, 11.

62. See Rankings, U.S. NEwS \& WORLD REP., http://www.usnews.com/rankings (last visited Mar. 7, 2012) (reporting rankings for the "Best Colleges" and "Best Graduate Schools"); U.S. News Staff, Why U.S. News Ranks Colleges and Universities, U.S. NEWS \& WORLD REP. (Sept. 12, 2011), http://www.usnews.com/education/best-colleges/articles/2011/09/12/why-us-news-ranks-collegesand-universities-2012 (explaining that U.S. News \& World Report ranks colleges and universities "to help [students] make one of the most important decisions of [their] li[ves].").

63. See Film Ratings: Informing Parents, Protecting Artistic Freedom, MOTION PICTURE Ass'N OF AM., http://mpaa.org/ratings (last visited Mar. 7, 2012).

64. See Eva Deuchert, Kossi Adjamah \& Florian Pauly, For Oscar Glory or Oscar Money?: Academy Award and Movie Success, 29 J. CulturAl ECON. 159, 172 (2005) ("[P]eople take the Oscar nominations and awards as a signal....”); About the Academy Awards, ACAD. OF MOTION PICTURE ARTS \& SCI., http://www.oscars.org/awards/academyawards/about/index.html (last visited Mar. 7, 2012).

65. See THE RazzIEs, http://www.razzies.com/ (last visited Mar. 7, 2012); John Mars, 'They Have No Excuse To Be As Bad As They Are,' GuARDiAn, Feb. 24, 2009, available at http://www.guardian.co.uk/film/2009/feb/24/razzies-interview-oscars (noting the Razzies probably boost DVD sales because they “'make people aware of films they wouldn't have gone to the cinema to see'”).

66. Furchtgott-Roth, Hahn \& Layne-Farrar, supra note 41, at 76-77, 79-80; About Us: Moody's Investors Service, MoODY’s CoRP., http://www.moodys.com/Pages/atc.aspx (last visited Mar. 7, 2012); Browse Ratings by Practice, STANDARD \& POOR's, http://www.standardandpoors.com/ ratings/en/us/ (last visited Mar. 7, 2012); FITCH RATINGs, http://www.fitchratings.com/web/en/ dynamic/fitch-home.jsp (last visited Mar. 7, 2012).

67. See, e.g., Nicholas Hastings, FOREX FOCUS: Impact of S\&P's Downgrade Spreads Far and Wide, Dow Jones INT'L NEWS, Jan. 16, 2012 (discussing impact of S\&P's credit downgrade of France and other European countries, including likely credit rating downgrade of European Financial Stability Facility); Alice Ross, Euro Falls on EFSF Downgrade, Fin. TIMES, Jan. 17, 2012, at 24 ("The euro failed to recover ground against the dollar following sharp falls on Friday after Standard \& Poor's, the rating agency, announced downgrades to various European countries including France and Austria.”); Jonathan Cheng, U.S. Stocks Drop, WALL ST. J., Jan. 13, 2012, http://online.wsj.com/ article/SB10001424052970204542404577158320667664132.html (reporting that U.S. stocks dropped in anticipation of the credit downgrade of several European countries). Cf. Simon Kennedy, Zeke Faux \& John Detrixhe, S\&P Downgrades See Muted Market Response, BLOOMBERG (Jan. 18, 2012, 12:17 AM), http://www.bloomberg.com/news/2012-01-18/s-p-gets-no-respect-from-investorsaccepting-lower-yields-after-downgrades.html ("The fallout in financial markets has been muted."). 
ratings to decide where and when to plump down television advertising dollars. $^{68}$ Reputationally concerned companies and socially and environmentally concerned citizens pay increasing attention to Corporate Social Responsibility rankings, such as the Corporate Social Responsibility Index (CSRI), which ranks public perceptions of companies' social and environmental citizenship, general governance, and employee relations. ${ }^{69}$

Rating systems often provide useful standards of comparison between products or services and facilitate more efficient transactions between buyers and sellers; they may also help overcome informational asymmetries. $^{70}$ In some cases, a reliable superior rating by a rating firm—such as an Underwriters Lab label—obviates the need for a consumer to obtain independent information about the quality or character of a product or service. ${ }^{71}$

Ratings can have a big impact on the profitability of affected companies and organizations. For example, companies look to Nielsen ratings to determine the value of advertising time and develop strategies for reaching specific demographic groups. ${ }^{72}$ Other examples illustrate how ratings can have a more immediate and direct financial effect on certain types of companies. Oscar nominations and awards can significantly increase box office revenues. $^{73}$ Likewise, upward movement for colleges and universities in the U.S. News rankings generally corresponds to an increase in applications, admissions, and, for public institutions, state funding. ${ }^{74}$

68. See Furchtgott-Roth, Hahn \& Layne-Farrar, supra note 41, at 52 n.11 (citing Nielsen Media Research, Frequently Asked Questions, http:/www.nielsen.com/us/en.html) (noting that although a television show may have millions of viewers, it may still be unpopular).

69. See Boston Coll. Ctr. Corp. Citizenship \& RepUtATion InST., The 2011 CSRI 50 (2011), http://www.bcccc.net/pdf/CSRIReport2011.pdf (showing the 2011 index).

70. See Furchtgott-Roth, Hahn \& Layne-Farrar, supra note 41, at 82-83 (offering an example of consumer credit agencies and other rating firms).

71. See id. at 83 \& n.156.

72. See id. at 52 .

73. See Deuchert, Adjamah \& Pauly, supra note 64, at 172 (“Our analysis of the 'Oscar effect' on revenues suggests that while the awards have a positive effect, the main box office effect is generated primarily by the nominations.”); Randy Nelson et al., What's an Oscar Worth?, 39 ECON. INQ. 1, 15 (2001) ("[A] nomination or award for the 'top' prizes, such as best picture and actress/actor, generally has a positive impact on a film's probability of survival, its market share of screens, and the average revenue per screen ....”); Heesun Wee, Investment Tips From Oscar?, BLOOMBERG BUSINESSWEEK, Mar. 21, 2002, http://www.businessweek.com/bwdaily/dnflash/ mar2002/nf20020321_6409.htm ("[O]ne of the most tangible benefits of awards and nominations is higher ticket sales. . . . [A]n Oscar nomination for Best Actor or Best Picture can add anywhere from $5 \%$ to $10 \%$ in additional box-office receipts for a studio.”).

74. See Nicholas A. Bowman \& Michael N. Bastedo, Getting on the Front Page: 
To the extent they are perceived by subject corporations as legitimate and powerful instrumentalities that impact corporate reputation, rating systems are likely to provoke a response. ${ }^{75}$ Corporate reputation is now recognized as a primary business driver, and the great majority of international companies now have some internal system for taking stock of their corporate reputation. ${ }^{76}$ Most companies monitor and take into consideration "media coverage, industry rankings and analyst commentary," and CEOs tend to be particularly sensitive to criticism in the media. ${ }^{77}$ Globally, as many as 180 published lists purport to assess one or more dimensions of, or factors affecting, corporate reputation. ${ }^{78}$ One helpful ranking tool is the CSRI, which was developed by the Reputation Institute ${ }^{79}$ in conjunction with the Boston College Center for Corporate Citizenship ${ }^{80}$ “to understand how companies' reputations are affected by public perceptions of performance related to citizenship (the

Organizational Reputation, Status Signal, and the Impact of U.S. News \& World Report on Student Decision, 50 RES. HigHER EDUC. 415, 415-17 (2009) (demonstrating an increase in undergraduate admissions indicators as a result of U.S. News and World Report rankings); Marc Meredith, Why Do Universities Compete in the Ratings Game? An Empirical Analysis of the Effects of the U.S. News and World Report College Rankings, 45 ReS. HigheR EDUC. 443, 443-44, 459-60 (2004) (concluding "college rankings affect admission outcomes"); Robert J. Morse, The Real and Perceived Influence of the US News Ranking, 33 Higher EdUc. EuR. 350, 350 (2008) (noting rankings appear to influence education policy at the state level, resulting in a boost in expenditures); see also Michael Sauder \& Ryon Lancaster, Do Rankings Matter? The Effects of U.S. News \& World Report Rankings on the Admissions Process of Law Schools, 40 L. \& SoC’Y REV. 105, 12732 (2006) (reporting similar findings for law schools).

75. See Amy E. Randel, Kimberly S. Jaussi \& Stephen S. Standifird, Organizational Responses to Negative Evaluation by External Stakeholders: The Role of Organizational Identity Characteristics in Organizational Response Formulation, 48 Bus. \& SOC’Y 438, 441 (2009), available at http://bas.sagepub.com/content/48/4/438 (summarizing scholarly support for concept that stakeholder influence on organizations is enhanced by "power, legitimacy and urgency").

76. Andrew Pharoah, Corporate Reputation: The Boardroom Challenge, 3 CORP. Gov. 46, 4651 (2003) (summarizing results of 2002 Hill and Knowlton Corporate Reputation Watch survey of "800 chief executives and senior managers" in the United States, Canada, and parts of Europe).

77. Id. at 48 .

78. The Reputation Institute collects many of these rankings as part of its service to companies and others that use its consulting services. See Reputation Rankings Database, REPUTATION INST., http://www.reputationinstitute.com/knowledge-center/list-of-lists (last visited Mar. 7, 2012).

79. The Reputation Institute describes itself as "the leading international organization devoted to advancing knowledge about corporate reputations and to providing professional assistance to companies interested in measuring and managing their reputations proactively.” About RI, REPUTATION INST., http://www.reputationinstitute.com/about-reputation-institute (last visited Mar. 7 , 2012). Founded in 1997, the Institute conducts annual survey interviews with tens of thousands of consumers in countries around the world regarding corporate reputation. Id.

80. The Center for Corporate Citizenship is a "membership-based research organization." About Us, BOSTON COLL. CTR. FOR CORP. CITIZENSHIP, http://www.bcccc.net/index.cfm (last visited Mar. 7, 2012). The Center "work[s] with global corporations to help them define, plan and operationalize their corporate citizenship.” Id. 
community and the environment), governance (ethics and transparency), and workplace practices." ${ }^{\text {"1 }}$ According to an executive at the Center for Corporate Citizenship, "Reputation ... is an indicator of how strongly connected consumers are to a brand. The effectiveness of a company's reputation management will influence the bottom line-in either a positive or negative manner." "82 The CSRI is compiled annually from data collected from online surveys, and it measures and publishes the perceptions of the practices of more than 200 major companies in the three social responsibility dimensions. ${ }^{83}$

Ratings may also be valuable to policymakers. For example, ratings have been used by those seeking to "defin[e] markets for antitrust or regulatory purposes.” 84

\section{B. Benefits of an Arbitration Fairness Index}

\section{Shining Light on Arbitration}

Boilerplate language in standardized agreements that binds parties to arbitration is an arcane and poorly understood aspect of consumer contracting and of employment relationships. ${ }^{85}$ Consumers and employees may have little or no idea about what a commitment to binding arbitration entails because only the tip of the arbitration "iceberg" may be visible to the eye at the time of contracting. ${ }^{86}$ They may not have access to the text of incorporated procedures and details

81. Tim Wilson, Publix Super Markets, Google and UPS Top List of 50 U.S. Companies with Best CSR Reputations, CTR. News \& Features Blog (Oct. 5, 2011, 12:39 PM), http://blogs.bcccc.net/2011/10/publix-super-markets-google-and-ups-top-list-of-50-u-s-companieswith-best-csr-reputations/.

82. Id. (quoting Katharine V. Smith, Executive Director of the Carroll School of Management Center for Corporate Citizenship at Boston College).

83. Id.; see also The 2011 CSRI 50, supra note 69; Boston. Coll. CTR. CoRP. CitIZENSHIP \& REPUTATION INST., THE 2010 CORP. SOCIAL RESPONSIBILITY INDEX (2010), http://www.bcccc.net/ pdf/CSRIReport2010.pdf.

84. Furchtgott-Roth, Hahn \& Layne-Farrar, supra note 41, at 52.

85. See Schmitz, supra note 4, at 134-36, 156-60 (noting that consumers typically care less about contract provisions that do not relate to price or quality and emphasizing that consumers may not understand arbitration terms altogether); see also FTC STUDY, supra note 20, at 41-42.

86. See Schmitz, supra note 4, at 149 ("[M]ost of the arbitration terms reviewed in the credit card and wireless service contracts were buried in long form contracts, and often appeared in unnoticeable or small typeface... [or] were slipped in 'bill stuffers' or included in e-contracts accessible only through website links or 'pop-ups' that consumers could easily bypass or overlook." (citing Ronald J. Mann \& Travis Siebeneicher, Just One Click: The Reality of Internet Retail Contracting, 20-24 (Univ. of Tex. Law \& Econ. Research Paper No. 104, 2007))); id. at 145 (noting credit card companies "rarely include or make available their full form contract terms"). 
regarding the administrative framework and panels of prospective arbitrators. Even if they did, very few have either the time or the ability to discern the import of specific procedures or potential loss of due process. $^{87}$ These realities are exacerbated by many individuals' belief that there is no point in trying to avoid or alter a company's arbitration provision, $^{88}$ or the privacy enshrouding these processes and the reluctance of some to submit program data to public gaze. ${ }^{89}$

A carefully developed Arbitration Fairness Index, scrutinizing and providing multi-faceted ratings of arbitration programs in consumer contracts or employment agreements would shine much-needed light on the nether worlds of consumer and employment arbitration. ${ }^{90}$ The Index would draw heavily upon legal standards, as well as due process protocols, securities arbitration procedures developed under the auspices of the SEC, and other norms. The Index, however, would avoid some of their limitations. Creating the Index-gathering data on and analyzing the operation of arbitration under specific contracts-would be a valuable tool for discussion and debate about fairness in arbitration, but without some of the distractions associated with legislative debates, such as political games, philosophical differences, and normative arguments over contract law and policy. ${ }^{91}$

The Index would draw broad public attention to arbitration programs and explain their workings. It would help acquaint and educate the public regarding the impact of class action waivers ${ }^{92}$ and other terms on

87. See id. at 150 (“[C]onsumers' eyes are likely to glaze over attempting to read and decipher companies' terms even when consumers get the opportunity to review advance copies.” (citing Shmuel I. Becher, Behavioral Science and Consumer Standard Form Contracts, 68 LA. L. REV. 117, 161-78 (2007))).

88. See FTC STUDY, supra note 20, at 43 ("Consumers generally do not negotiate or try to negotiate the arbitration provisions ... because they may not believe they have any alternative given that all of the companies in the relevant industry ... have arbitration provisions in their contracts."); Schmitz, supra note 4, at 129 ("[C]onsumers rarely negotiate boilerplate that they may not read or understand." (citing Todd D. Rakoff, The Law and Sociology of Boilerplate, 104 MicH. L. REV. 1235, 1240-43 (2006))); id. at 152 (noting a belief of a focus group participant that she did not have the "leverage to negotiate" a change to a form contract).

89. See Stipanowich, supra note 2, at 422.

90. See FTC STUDY, supra note 20, at 67-71 (discussing the need for more information about consumer arbitration cases and dispositions and supporting monitoring and evaluation of debt collection arbitration programs).

91. The history and continuing evolution of arbitration between investors and brokers to debate and formulate policies and procedures under the eye of the SEC illustrates the potential benefits to be derived by gathering a group of experienced, thoughtful, and articulate representatives of respective stakeholders (e.g., employers and employees, producers of goods and services, and consumers). See Stipanowich, supra note 2, at 384-85.

92. Studies examining arbitration provisions in consumer contracts have found that these 
consumer or employee rights. It would provide many points of comparison among programs. Consumers and employees could thus understand how a particular company's arbitration program stacks up in the same way they obtain multifaceted comparisons of other products or services by reading Consumer Reports. ${ }^{93}$

The Index would also serve as a more dependable and useful source of information than reports that employ selective data in isolation. ${ }^{94}$ Instead of focusing on individual horror stories, which may not be wholly representative of particular programs, ${ }^{95}$ the Index would examine programs in all of their aspects. Ratings would be based on a variety of sources of information, including reports of personal experiences and statistics.

The Index would offer a more fulsome and accurate picture of arbitration programs in practice, and potentially create a more balanced and nuanced public perception of arbitration programs. There is, for example, some evidence that parties are more likely to get to a hearing in arbitration than in court. ${ }^{96}$ In the securities arena, there is evidence that arbitration provides the preferred-and perhaps the only feasible—path

provisions are invariably paired with class-action waivers. See Eisenberg, Miller \& Sherwin, supra note 36, at 121 (finding that all contracts studied include such waivers); Schmitz, supra note 4, at 148 (same). The presumption is that companies provide for mandatory arbitration simply as a way to prohibit collective action in a manner that would probably survive judicial scrutiny. See Eisenberg, Miller \& Sherwin, supra note 36, at 122 (noting such clauses seek "to prevent aggregation of consumer claims”); Schmitz, supra note 4, at 148; see also Jean R. Sternlight, Tsunami: AT\&T Mobility v. Concepcion Impedes Access to Justice, 91 OR. L. REV. (forthcoming 2012) (manuscript at 15-17). Many of the contracts studied provided that the arbitration was void in the event class arbitration was ordered, thus funneling any collective action to the courts. See Eisenberg, Miller \& Sherwin, supra note 36, at 122; Schmitz, supra note 4, at 148.

Class-action waivers are the subject of much controversy, Stipanowich, supra note 2, at 336, 371, 425 \& n.72, particularly since the U.S. Supreme Court's decision in AT\&T Mobility LLC v. Concepcion, 131 S. Ct. 1740 (2011). See infra text accompanying notes 427-37.

93. See supra text accompanying note 57.

94. See, e.g., Sarah R. Cole \& Kristen M. Blankley, Empirical Research on Consumer Arbitration: What the Data Reveals, 113 PENN. St. L. REV. 1051 (2009) (extensively critiquing the analysis and conclusions of the 2007 Public Citizen report entitled, "The Arbitration Trap: How Credit Card Companies Ensnare Consumers").

95. See, e.g., id. at 1059, 1061 (criticizing the report for relying on anecdotal evidence where statistical data is lacking).

96. See, e.g., Bales \& Eviston, supra note 38, at 10 (noting that opponents of the Arbitration Fairness Act of 2009 argue that employees "are more likely to prevail" in arbitration than in court because of the reduced emphasis on motions to dismiss and summary judgment in arbitration); SECS. IndUS. \& Fin. MKTS. Ass'N, White PAPER ON ARBITRATION IN THE SECURITIES INDUSTRY 31-33 (2007), available at www.sifma.org/WorkArea/DownloadAsset.aspx?id=21334 (parties to securities arbitration are, among other things, more likely to see their claim decided on the merits after full factual discovery). 
for certain kinds of investor claims. ${ }^{97}$ The same may be true of some employment claims. ${ }^{98}$

To the extent the Index imposes appropriate downgrades for companies that fail to share required information regarding their arbitration programs, including rules and procedures, arbitration panel members, administrative practices, and case statistics, ${ }^{99}$ the Index could stimulate a great deal more transparency in corporate practices. Moreover, the Index would shed additional light on the policies and practices of organizations providing arbitration services under corporate contracts. As explained below, enhanced awareness and scrutiny of these largely unregulated private justice-providers is long overdue. ${ }^{100}$ In these respects the Index would transcend some of the inherent limitations of due process protocols and other fairness standards, which in many cases depend to a great extent on the good faith and commitment of companies and organizations providing consumer or employment arbitration services. ${ }^{101}$

\section{Other Potential Benefits}

In addition to enhancing public awareness and understanding consumer and employment arbitration programs, the Arbitration Fairness

97. See, e.g., Barbara Black, Is Securities Arbitration Fair to Investors?, 25 PACE L. REV. 1, 2 (2004) (“[I]nvestors may fare better in arbitration than in litigation.”); Jill I. Gross, McMahon Turns Twenty: The Regulation of Fairness in Securities Arbitration, 76 U. CIN. L. REV. 493, 517-20 (2008) (concluding “as a result of SEC oversight, investors have access to a fundamentally fair dispute resolution process that enables them to vindicate their statutory rights to the same degree as, if not more so, than in court”).

98. See, e.g., Michael Delikat \& Morris M. Kleiner, An Empirical Study of Dispute Resolution Mechanisms: Where Do Plaintiffs Better Vindicate Their Rights?, DisP. RESOL. J., Nov. 2003-Jan. 2004, at 58 ("[P]laintiffs with employment claims are well served by arbitration relative to the federal courts, both in terms of speedy justice and the likelihood of a positive outcome.”).

99. Failure to provide the information necessary to rate the fairness of an arbitration program could result in a lower rating. For example, when colleges fail to fill out the statistical surveys, U.S. News \& World Report relies on estimates or other sources to fill in the gaps. See Robert Morse \& Sam Flanigan, How U.S. News Calculates the College Rankings, U.S. NEWS \& WORLD REPORT (Sept. 12, 2011), http://www.usnews.com/education/best-colleges/articles/2011/09/12/how-us-newscalculates-the-college-rankings-2012. Some have claimed that these estimations result in a lower ranking than if the schools had provided the data. MICHAEL SAUDER \& WENDY ESPELAND, FEAR OF FALling: THE EFFECTS OF U.S. NEWS \& WORLD REPORT RANKINGS ON U.S. LAW SCHOOLS 5 (2007), available at http://www.lsac.org/lsacresources/Research/GR/GR-07-02.pdf.

100. See generally Thomas J. Stipanowich, Behind the Neutral: The Critical Role of Provider Institutions, in AMERICAN ARBITRATION ASSOCIATION HANDBOOK ON COMMERCIAL ARBITRATION 47 (Thomas Carbonneau \& Jeanette A. Jaeggi eds., 2010) (discussing the positive influence providers can have on the conflict resolution process).

101. See infra text accompanying notes 224-28. 
Index would undoubtedly impact corporate behavior. It would provide incentives to businesses and business sectors to develop and maintain fair, effective arbitration programs for consumers and employees. The Index would discourage companies from employing proprietary (inhouse, self-administered) programs ${ }^{102}$ as well as provisions that limit remedies and procedures that would otherwise be available. ${ }^{103}$ The Index may also help push the envelope by encouraging companies to provide tangible incentives for consumers or employees to choose arbitration.

Finally, implementing an Arbitration Fairness Index would provide a more solid foundation for the future development of arbitration law and policy. ${ }^{104}$ A more complete picture of consumer and employment arbitration and particularly troublesome cases may support new approaches to statutory reform or regulatory action. ${ }^{105}$ Whether one supports the enforcement of arbitration agreements as a way of ensuring the protection of individuals' rights through compensatory or specific relief, or believes, additionally, that arbitration programs must permit-if not effectively promote-appropriate punishment and deterrence, ${ }^{106}$ a greater understanding of the structure and functioning of arbitration programs is essential. In addition, the very process of developing and implementing an Arbitration Fairness Index will engender a valuable conversation about how arbitration serves, or should be made to serve, different kinds of justice-distributive, retributive or corrective, procedural, and compensatory.

\section{Guidelines for Developing an Arbitration Fairness Index}

A useful set of guidelines for the development of ranking systems emerged from the global dialogue regarding rankings of institutions of higher education by U.S. News \& World Report and other journals. ${ }^{107}$ In

\footnotetext{
102. See infra Part IV.C.

103. See, e.g., infra Part IV.F.1.

104. See Stipanowich, supra note 2, at 427-33 (describing potential process options for future resolution of consumer or employment disputes).

105. See id. at 396-406 (summarizing recent or proposed legislation affecting arbitration, including the Arbitration Fairness Act of 2011 and regulatory authority granted to the new Consumer Financial Protection Bureau (CFPB) and the SEC).

106. See generally Thomas J. Stipanowich, Punitive Damages and the Consumerization of Arbitration, 92 NW. U. L. REV. 1 (1997) (addressing concerns regarding availability of exemplary damages in arbitration).

107. See College and University Ranking Systems: Global Perspectives and AMERICAN CHALLENGES 2-4 (2007) [hereinafter RANKING SYSTEMS]; Rankings, supra note 62.
} 
2004, an International Rankings Expert Group (IREG) was formed to bring together individuals from around the world who create rankings or evaluate rankings programs. ${ }^{108}$ IREG developed The Berlin Principles on Ranking of Higher Education Institutions, ${ }^{109}$ a framework for the development and publication of higher education rankings that are intended to promote "continuous improvement and refinement of ... ranking [systems]." " The Berlin Principles include several considerations that are particularly relevant to the development of an Arbitration Fairness Index, to wit:

Purposes and Goals of Rankings[:]

1. . . . Rankings can provide comparative information and improved understanding [of the rated programs but should be viewed as complementary to other sources of information]. ${ }^{111}$

2. . . . Rankings have to be designed with due regard to their purpose.... ${ }^{112}$

3. ... Institutions that are being ranked and the experts that inform the ranking process should be consulted often. ... ${ }^{113}$

4. [Rankings should p]rovide clarity about the range of information sources for rankings. ${ }^{114}$ [A variety of courses should be combined] in order to get a more complete view .... 115

5. Specify the linguistic, cultural, economic, and historical contexts of the educational systems being ranked. ... ${ }^{116}$

Design and Weighting of Indicators[:]

6. Be transparent regarding the methodology used for creating the rankings. ... 117

\footnotetext{
108. IREG was established at a meeting co-hosted by the Institute for Higher Education Policy (IHEP) and the UNESCO European Centre for Higher Education (UNESCO-CEPES). RANKING SYSTEMS, supra note 107 , at $2-3$.

109. Id. at 51.

110. Id.

111. Id.

112. Id. at 52 .

113. Id.

114. Id. (emphasis omitted).

115. Id.

116. Id. (emphasis omitted).

117. Id. (emphasis omitted).
} 
7. Choose indicators according to their relevance and validity. ... ${ }^{118}$

8. Measure outcomes in preference to inputs whenever possible. .. ${ }^{119}$

9. Make the weights assigned to different indicators (if used) prominent .... ${ }^{120}$

Collection and Processing of Data[:]

10.[B]e ... objective and impartial [in the collection and use of data]. ${ }^{121}$

11. Use audited and verifiable data whenever possible. . . ${ }^{122}$

12. Include data that are collected with proper procedures for scientific data collection. ... ${ }^{123}$

13. Apply measures of quality assurance to ranking processes themselves. ... ${ }^{124}$

14. Apply organizational measures [such as advisory or supervisory bodies] that enhance the credibility of rankings. ... ${ }^{125}$

Presentation of Ranking Results[:]

15. Provide consumers with a clear understanding of all the factors used to develop a ranking, and offer them a choice in how rankings are displayed. ${ }^{126}$

The remainder of this Article is devoted to the development and implementation of an Arbitration Fairness Index, with some emphasis on the criteria listed above. In light of our purpose of developing a rating system aimed at providing consumers and employees with "comparative information and improved understanding"127 about the relative attributes and implications for fairness of corporate arbitration programs, we will

\footnotetext{
118. Id. (emphasis omitted).

119. Id. (emphasis omitted).

120. Id. (emphasis omitted).

121. Id. at 53.

122. Id. (emphasis omitted).

123. Id. (emphasis omitted).

124. Id. (emphasis omitted).

125. Id. (emphasis omitted).

126. Id. (emphasis omitted)

127. Id. at 4.
} 
first consider various standards and programs that might serve as exemplars suggesting the kinds of elements - or, to use the term in the Berlin Principles, "indicators"128 — that would be most relevant and valid in a comprehensive rating system.

\section{ANALYSIS: EXEMPLARS AND FOUNDATIONS FOR AN ARBITRATION FAIRNESS INDEX}

A rating system should reflect general "agreement on what needs to be measured" and what standards should be applied. ${ }^{129}$ When it comes to elements of fairness in employment and consumer arbitration programs, fortunately, there is a wide array of relevant and mutually reinforcing exemplars from a growing variety of sources. We have pertinent legislation, ${ }^{130}$ numerous court decisions regarding fairness in arbitration under consumer or employment contracts, ${ }^{131}$ "due process protocols" the American Arbitration Association (AAA) developed with input from other stakeholders and translated into administered procedures, ${ }^{132}$ "minimum fairness standards" adopted by JAMS, ${ }^{133}$ procedures and practices established by the Better Business Bureau, ${ }^{134}$ a robust framework for investor/broker arbitration overseen by the SEC, ${ }^{135}$ principles to govern institutions providing arbitration and other dispute resolution services, ${ }^{136}$ and recent findings and recommendations by the FTC respecting arbitration of debt collection disputes. ${ }^{137}$ Moreover, and most importantly, are initiatives to establish a framework for the global implementation of online dispute resolution-the engine that promises to vastly transform our experience with and expectations regarding dispute resolution. ${ }^{138}$

In addition to these standards or programs that suggest parameters or "inputs" for an Arbitration Fairness Index, there are empirical studies that attempt to capture the range of actual contracting behaviors in

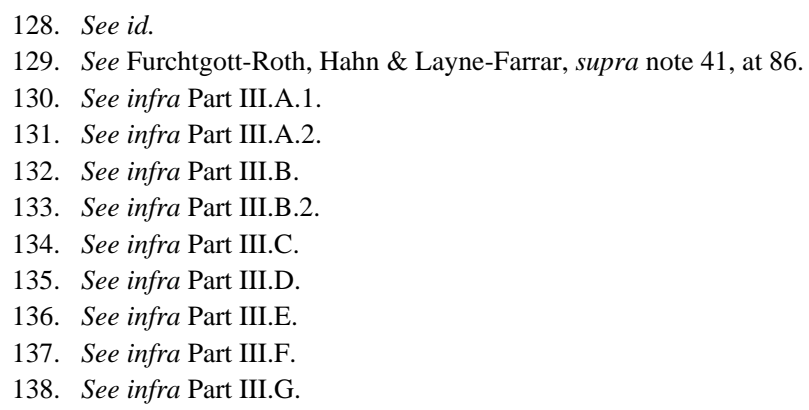


consumer and employment arbitration agreements and also measure outcomes of consumer and employment arbitration processes. ${ }^{139}$ These outcomes include not only win-loss rates in arbitration and their comparison to statistics from court systems, ${ }^{140}$ but also summaries of perceptions of arbitration processes by consumers and other users. ${ }^{141}$

These developments-nearly all products of the last two decades ${ }^{142}$ - may be viewed through the lens that defines and measures arbitration as an engine of compensatory justice - that is, the fair compensation of injuries by those who caused them. ${ }^{143}$ To a significantly lesser degree such a view also embodies concepts of arbitration as a source of retributive or corrective justice. ${ }^{144}$ This is best illustrated by court decisions, legislation, rules of arbitration procedure, and other standards recognizing the authority of arbitrators to award punitive or exemplary damages in the manner of a court. ${ }^{145}$ These latter concernswhen manifested in the view that arbitration cannot be an effective vehicle for punishment and deterrence-help animate opposition to class action waivers in arbitration agreements. ${ }^{146}$

These same initiatives and empirical findings about arbitration may also be considered from the perspective of social or distributive justicethat is, fair, or perceptibly fair, adjudicated outcomes for individuals regardless of their relative power or bargaining strength. ${ }^{147}$ These

139. See infra Part III.H.

140. See infra text accompanying note 293-94.

141. See infra text accompanying notes 290 and 295.

142. See infra Part III.H.

143. See Richard W. Wright, Substantive Corrective Justice, 77 IOWA L. REV. 625, 671 (1992) ("Compensatory justice is the principle whereby faulty injurers who cause such unjust losses are required to rectify those losses.”).

144. "Retribution" is defined as an "aspect of justice that requires the return of harm for harm." Brian H. BIX, A Dictionary of LEgal THEORY 186 (2004); see also Morton Deutsch, Justice and Conflict, in The Handbook of Conflict Resolution: Theory \& Practice 43, 51 (Morton Deutsch, Peter T. Coleman \& Eric C. Marcus eds., 2d ed. 2006) ("The psychology of retributive and reparative justice is concerned with the attitudes and behavior of people in response to moral rule breaking.").

145. See, e.g., Mastrobuono v. Shearson Lehman Hutton, Inc., 514 U.S. 52, $62-64$ (1995) (holding punitive damages permissible under an arbitration agreement but not under this particular agreement); UNIF. ARBITRATION ACT § 21(a) (amended 2000) (“An arbitrator may award punitive damages or other exemplary relief if such an award is authorized by law in a civil action involving the same claim and the evidence produced at the hearing justifies the award under the legal standards otherwise applicable to the claim.”).

146. See Sternlight, supra note 92, at 23-24 (describing the necessity of class actions to protect plaintiffs' rights and deter defendants "from engaging in illegal conduct").

147. See Nancy A. Welsh, Remembering the Role of Justice in Resolution: Insights from Procedural and Social Justice Theories, 54 J. LEgAL EDUC. 49, 55-56 (2004) [hereinafter Welsh, 
standards represent efforts to adjust the playing field for private adjudication under standardized contracts of adhesion in which consent by consumers or employees is often neither informed nor free, while empirical studies reflect the breadth of actual practice and resulting perceptions.

Finally, the following initiatives and studies exemplify the indisputable link between views on outcomes in justice systems and the key component of procedural justice-whether "a dispute resolution process is procedurally fair." ${ }^{148}$ These components include: (1) the opportunity for a disputant to express views or to tell his or her story“"an opportunity for voice"”- - to a third party; ${ }^{149}$ (2) the ability of a third party - in this case, presumably, the arbitrator and perhaps the arbitration institution - to "demonstrate[] consideration of what the disputants have said"; ${ }^{150}$ (3) "the [requirement that a] third party treat[] the disputants in an even-handed way and tries to be fair"; ${ }^{151}$ (4) "the [requirement that a] third party treat[] the disputants with dignity and respect"; ${ }^{152}$ and (5) the assurance that the process itself is dignified. ${ }^{153}$ Much hinges on these perceptions. ${ }^{154}$

\section{A. Legal Standards Affecting Consumer and Employment Arbitration}

\section{Legislation}

Despite the fact that the FAA has been interpreted to be broadly preemptive of state legislation limiting the enforceability of arbitration agreements, ${ }^{155}$ some state legislatures have established special formal

Remembering the Role of Justice] (discussing "merging” of social and procedural justice under John Rawls' theory of justice as fairness); Nancy A. Welsh, Making Deals in Court-Connected Mediation: What's Justice Got to Do with It?, 79 WASH. U. L. Q. 787, 817 (2001) [hereinafter Welsh, Making Deals] ("Distributive justice ... focuses on perceptions of and criteria to determine the substantive fairness of . . . outcomes themselves.").

148. See Welsh, Remembering the Role of Justice, supra note 147, at 52 (discussing the elements that lead people to conclude whether "a dispute resolution process is procedurally fair").

149. Id. (citing Welsh, Making Deals, supra note 147, at 820-22, 841-44).

150. Id. (citing Welsh, Making Deals, supra note 147, at 820-23).

151. Id. (citing Welsh, Making Deals, supra note 147, at 821-24).

152. Id. (citing Welsh, Making Deals, supra note 147, at 820-26).

153. Welsh, Making Deals, supra note 147, at 820.

154. See generally id. at 820-30 (discussing elements of procedural fairness, consequences of perceived procedural fairness, and theoretical underpinnings of procedural fairness).

155. See Preston v. Ferrer, 552 U.S. 346, 353 (2008) (“The FAA’s displacement of conflicting state law is 'now well-established.'” (quoting Allied-Bruce Terminix Cos. v. Dobson, 513 U.S. 265, 272 (1995))); see also Stipanowich, supra note 2, at 328-30 (discussing the Supreme Court's ruling 
requirements intended to promote greater awareness or understanding of arbitration agreements. The Revised Uniform Arbitration Act (RUAA) ${ }^{156}$ and the California Ethics Standards ${ }^{157}$ stand out as examples of such efforts to promote due process in other ways.

When the Uniform Arbitration $\mathrm{Act}^{158}$ - the primary model for state arbitration law in the United States-was revised by the National Conference of Commissioners on Uniform State Laws in 2000 (RUAA), it was greatly expanded and fleshed out to provide more detailed direction for courts and, to some extent, arbitrators. ${ }^{159}$ Concerns about the rights of consumers and employees brought into arbitration under standardized contracts were a prime motivator of reforms. ${ }^{160}$ Hence, the RUAA incorporates many additional procedural default rules and several mandatory and non-waivable procedural elements. ${ }^{161}$ Among other things, the Act expressly requires disclosures by arbitrators; ${ }^{162}$ sets requirements for notice of hearings; ${ }^{163}$ gives all parties the right to have a lawyer present; ${ }^{164}$ specifically authorizes arbitrators to issue subpoenas, request depositions, and partake in arbitrator-supervised discovery; ${ }^{165}$ and permits a wide range of remedies, including punitive damages and attorney's fees as authorized by law. ${ }^{166}$ By making these elements more explicit, and in some cases non-waivable, the drafters sought to promote various requirements of due process. ${ }^{167}$

Some years ago the California Arbitration Act was modified to require arbitrators and organizations providing consumer arbitration

in Stolt-Nielsen that interpreted Congress' power to preempt state law under the FAA).

156. UNIF. ARBITRATION ACT (amended 2000).

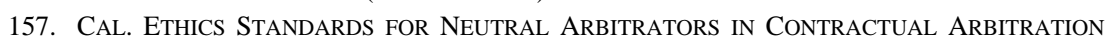
(2007), available at http://www.courts.ca.gov/documents/ethics_standards_neutral_arbitrators.pdf.

158. UNIF. ARBITRATION ACT (1956) (amended 2000).

159. See Unif. ARbitration Act Prefatory Note (amended 2000); see also Stipanowich, supra note 15, at 20-21 ("When the RUAA ... was published in 2000, it incorporated many new elements that reflect the 'legalization' of arbitration.”).

160. Id. at 44. The author speaks from personal knowledge. He was one of two official academic advisors to the NCCUSL study committee working with the Reporter, was present at most of the meetings of the committee, and assisted in drafting the revisions.

161. See Unif. ARbitration Act $\S 4$ (amended 2000) (detailing the non-waivable elements of the RUAA that did not exist in the original UAA).

162. Id. § 12 .

163. Id. § 15(c).

164. Id. § 16 .

165. Id. $\S 17(\mathrm{a})-(\mathrm{c})$.

166. Id. § 21(a)-(b).

167. See id. Prefatory Note. 
services to make disclosures relating to possible conflicts of interest. ${ }^{168}$ Enacted as the California Ethics Standards, ${ }^{169}$ these provisions also were stimulated by concerns regarding consumer and employment arbitration. ${ }^{170}$ Among other things, the Standards require arbitrators to disclose "all matters that could cause a person aware of the facts to reasonably entertain a doubt that the proposed arbitrator would be able to be impartial." ${ }^{\prime 71}$ Importantly, the Standards also call upon organizations providing consumer arbitration services in California to make broad disclosures. ${ }^{172}$ This has had the beneficial effect of requiring provider organizations to make public a wide range of data regarding consumer and employment cases they have administered. As a result, institutions such as the American Arbitration Association (AAA) and Judicial Arbitration and Mediation Service (JAMS) have made public extensive data collected from arbitrations conducted not just in California but throughout the nation. ${ }^{173}$

\section{Judicial Decisions}

Federal and state court decisions policing arbitration agreements offer another set of guideposts for describing and evaluating the fairness of arbitration programs. Under legal concepts such as fraud, the covenant of good faith and fair dealing, the doctrine of reasonable expectations, and above all, the unconscionability doctrine, ${ }^{174}$ courts have delineated a variety of due process elements. These elements

168. See CAL. Civ. Proc. CoDE § 1281.85 (West 2007).

169. CAL. ETHICS STANDARDS, supra note 157.

170. See Jevne v. Superior Court, 111 P.3d 954, 962 (Cal. 2005) (citing Cal. Assembly Comm. on Judiciary, Analysis of Senate Bill No. 475, S. 475, 107th Cong. (2001)); Jay Folberg, Arbitration Ethics-Is California the Future?, 18 OHIO ST. J. ON DisP. Resol. 343, 343-44 (2003).

171. CAL. ETHICS STANDARDS, supra note 157, Standard 7(d).

172. In arbitrations administered by a provider organization that involve a consumer, employment, or healthcare contract, arbitrators are required to disclose any financial or professional relationships between the provider organization and any party, lawyer, or law firm involved in the arbitration. Id. Standards 2(d)-(e), 8(b)(1)(A). If such a relationship exists, the arbitrator must also disclose his or her relationship with the provider organization. Id. Standard 8(c).

173. See, e.g., Consumer Arbitration Statistics, AM. ARB. Ass'N, available at http://www.adr.org/ (last visited Apr. 11, 2012) (search for "Consumer Arbitration Statistics") [hereinafter Consumer Arbitration Statistics] (providing arbitration-related statistics for California and other states); JAMS Disclosures for California and Washington, D.C. Consumer Arbitrations, JAMS, http://www.jamsadr.com/consumer-arbitration-disclosures/ (last visited Apr. 11, 2012) [hereinafter JAMS Disclosures] (providing ADR data for California).

174. For a review of the use of the unconscionability doctrine to police unfairness in arbitration agreements before and after AT\&T Mobility LLC v. Concepcion, see Stipanowich, supra note 2, at 351-60, 380-87. 
include: a fair, balanced program under pre-dispute agreements for binding arbitration; ${ }^{175}$ materially accurate information to the public regarding program operation; ${ }^{176}$ impartial and independent arbitrators; ${ }^{177}$ a hearing location that is reasonably close; ${ }^{178}$ reasonable costs and fees; ${ }^{179}$ adequate access to information and discovery; ${ }^{180}$ remedies that

175. See, e.g., Hooters of Am., Inc. v. Phillips, 173 F.3d 933, 938-40 (4th Cir. 1999) (holding that arbitration agreement was unenforceable because Hooters' arbitration rules and procedures were "so one-sided that their only possible purpose [wa]s to undermine the neutrality of the proceeding" and "creat[e] a sham system unworthy even of the name of arbitration").

176. See, e.g., Engalla v. Permanente Med. Grp., Inc., 938 P.2d 903, 922 (Cal. 1997) (concluding "there is evidence to support [plaintiff's] claims that [defendant] fraudulently induced [plaintiff] to enter the arbitration agreement in that it misrepresented the speed of its arbitration program").

177. See, e.g., Walker v. Ryan's Family Steak Houses, Inc., 400 F.3d 370, 385-88 (6th Cir. 2005) (holding, inter alia, that arbitration agreements were unenforceable because the forum did not allow for the effective vindication of plaintiffs' rights, and the arbitral forum provided was not neutral because employer and third-party agency responsible for designating arbitrators had a “symbiotic relationship”); McMullen v. Meijer, Inc., 355 F.3d 485, 492-94 (6th Cir. 2004) (holding that an employer's termination appeal procedure was not "an effective substitute for a judicial forum" where employer had "unilateral control over the pool of potential arbitrators").

178. See, e.g., Fields v. NCR Corp., 683 F. Supp. 2d 980, 989-90 (S.D. Iowa 2010) (finding arbitration procedures - including a provision that the hearing "be 'conducted at a neutral location, in or near the [employee's city]'”- - were fair and "[did] not impose any substantial inequities or hardships on an employee that might seek arbitration thereunder”); Dale v. Terminix Int'l Co., No. B162108, 2003 WL 22511633, at*2-3 (Cal. Ct. App. Nov. 6, 2003) (“[B]ecause [the arbitration provision] guarantees that any arbitration hearing will be near [plaintiff]'s residence, we find it to be reasonable.”).

179. See, e.g., Cole v. Burns Int'l Sec. Servs., 105 F.3d 1465, 1485 (D.C. Cir. 1997) (holding that the arbitration agreement was "valid and enforceable" because "[plaintiff] could not be required to agree to arbitrate his public law claims as a condition of employment if the arbitration agreement required him to pay all or part of the arbitrator's fees and expenses"); Nazon v. Shearson Lehman Bros., Inc., 832 F. Supp. 1540, 1543 (S.D. Fla. 1993) (holding agreement to arbitrate where plaintiff had to initiate the claim and pay applicable fees was nonetheless reasonable because plaintiff could apply for a fee waiver); Gutierrez v. Autowest, Inc., 7 Cal. Rptr. 3d 267, 277 (Ct. App. 2003) ("We conclude that where a consumer enters into an adhesive contract that mandates arbitration, it is unconscionable to condition that process on the consumer posting fees he or she cannot pay. It is self-evident that such a provision is unduly harsh and one-sided, defeats the expectations of the nondrafting party, and shocks the conscience. While arbitration may be within the reasonable expectations of consumers, a process that builds prohibitively expensive fees into the arbitration process is not." (footnote omitted) (citing Patterson v. ITT Consumer Fin. Corp., 18 Cal. Rptr. 2d 563 (Ct. App. 1993))).

180. See, e.g., Openshaw v. FedEx Ground Package Sys., Inc., 731 F. Supp. 2d 987, 995 (C.D. Cal. 2010) (holding, inter alia, arbitration agreement substantively unconscionable because "the discovery provision [favored defendant] while stacking the deck against a contractor seeking to establish liability for wrongful termination," which "[w]hether by design or effect, ... denie[d] contractors a fair opportunity to develop the evidence necessary to support their claims”); Ostroff v. Alterra Healthcare Corp., 433 F. Supp. 2d 538, 545-46 (E.D. Pa. 2006) (holding an arbitration agreement substantively unconscionable because discovery was limited to expert depositions, which would have made it impossible for plaintiff to support many of her claims for relief under the facts of the case); Fitz v. NCR Corp., 13 Cal. Rptr. 3d 88, 97-100, 101-05 (Ct. App. 2004) (holding that the arbitration agreement's limitation on discovery did not permit the fair vindication of rights in an arbitral forum and hence the agreement was procedurally and substantially unconscionable). 
would be available in a court of law; ${ }^{181}$ and access to information about related cases. ${ }^{182}$

The most contentious issue of all involves class-action waivers in connection with arbitration agreements; ${ }^{183}$ courts have divided on their enforceability. ${ }^{184}$ Recently, the Supreme Court ruled that such waivers are enforceable, at least in certain circumstances. ${ }^{185}$ Whatever the current state of the law, however, the option of class or collective action may be perceived as a critical element of fairness for consumers and employees.

\section{B. The Due Process Protocols}

Concerns about privatized justice under adhesion contracts also prompted the development of what are effectively self-regulatory guidelines by organizations providing dispute resolution services. ${ }^{186}$ Beginning in the mid-1990s, the AAA and other organizations engaged in collaborative efforts aimed at establishing minimum standards for the management of employment, ${ }^{187}$ consumer ${ }^{188}$ and health care, ${ }^{189}$ and debt

181. See, e.g., Lozada v. Dale Baker Oldsmobile, Inc., 91 F. Supp. 2d 1087, 1105 (W.D. Mich. 2000) (holding an arbitration agreement excluding class action, declaratory, and injunctive remedies, which would be otherwise available through state statute, did so impermissibly and, thus, was substantively unconscionable); Stirlen v. Supercuts, Inc., 60 Cal. Rptr. 2d 138, 143-46, 152 (Ct. App. 1997) (holding arbitration agreement procedurally and substantively unconscionable because it denied or limited the recovery of remedies that would have remained available through litigation).

182. See, e.g., Davis v. O’Melveny \& Myers, 485 F.3d 1066, 1078-79 (9th Cir. 2007) (holding a confidentiality clause of an arbitration agreement unconscionable because it limited the ability of claimaints to pursue their claims and interview witnesses); Ting v. AT\&T, 319 F.3d 1126, 1151-52 (9th Cir. 2003) (holding that an arbitration agreement confidentiality clause was substantively unconscionable).

183. See Stipanowich, supra note 2, at 336.

184. See id. at $336 \&$ n. 70 .

185. AT\&T Mobility LLC v. Concepcion, 131 S. Ct. 1740, 1750-51 (2011). For a discussion of Concepcion, see Stipanowich, supra note 2, at 371-96.

186. To some extent, "self-regulation bolsters the perceived legitimacy" of consumer and employment arbitration. See Carole J. Buckner, Due Process in Class Arbitration, 58 FLA. L. REV. 185, 225 (2006).

187. See Am. Arbitration Ass'n, Employment Due Process Protocol (1995), available at http://www.adr.org (search for "Employment Due Process Protocol") [hereinafter EMPLOYMENT PROTOCOL] ("The following protocol is offered ... as a means of providing due process in the resolution by mediation and binding arbitration of employment disputes involving statutory rights.").

188. See CONSUmer PROTOCOL, supra note 33 (containing fifteen principles to ensure a fair ADR process for consumers).

189. See AM. ARbitration Ass'n, Comm'n on Health Care Dispute Resolution, Healthcare Due Process Protocol (1998), available at http://www.adr.org (search for "Healthcare Due Process Protocol") [hereinafter HEALthCARE PROTOCOL]. 
collection disputes. ${ }^{190}$ The Employment Due Process Protocol and the more expansive Consumer Due Process Protocol were the first significant efforts to create a common floor of expectations for a fundamentally fair dispute resolution process. They served as templates for the AAA's employment and consumer arbitration procedures and heavily influenced other providers' initiatives. ${ }^{191}$

\section{Employment Due Process Protocol}

In 1993, the Dunlop Commission observed that arbitration under collective bargaining agreements was fair because unions' collective power counterbalanced employers' power; the Commission expressed concern that this balance did not exist in arbitration under contracts with non-union employees. ${ }^{192}$ "The Commission then asked the National Academy of Arbitrators" to develop standards for such scenarios, and a Task Force on Alternative Dispute Resolution, comprised of representatives of diverse constituencies, was assembled for that purpose. ${ }^{193}$

The participants in the Task Force were of differing minds regarding the appropriateness of enforcing pre-dispute arbitration agreements in individual employment contracts. Therefore, they reflected a number of varying perspectives on the issue. ${ }^{194}$ They nevertheless reached consensus on key due process elements of employment arbitration, including: the right of representation, access to information and discovery, qualified arbitrators, arbitrator disclosures of conflicts of interest, and arbitrator authority to render the same relief as a court. ${ }^{195}$ The resulting Protocols became the template for employment arbitration procedures at two leading dispute resolution provider institutions, ${ }^{196}$ the AAA $^{197}$ and JAMS. ${ }^{198}$

190. See Am. Arbitration Ass'n, Nat'L Task Force on the Arb. of Consumer Debt Collection Disputes, Consumer Debt Collection Due Process Protocol-Statement of PRINCIPLES (2010), available at http://www.adr.org (search for "Debt Collection Due Process Protocol”) [hereinafter DeBT ColleCtion PROTOCOL].

191. See infra text accompanying notes 192-234.

192. See Bales \& Eviston, supra note 38, at 11; Richard A. Bales, The Employment Due Process Protocol at Ten: Twenty Unresolved Issues, and a Focus on Conflicts of Interest, 21 OHIO ST. J. ON DISP. RESOL. 165, 171 (2005).

193. See Bales \& Eviston, supra note 38, at 11-12; Bales, supra note 192, at 171-72.

194. See EMPLOYMENT PROTOCOL, supra note 187, at 1.

195. See id. at $2-4$.

196. See Bales, supra note 192, at 174.

197. See id.; see also Am. Arbitration Ass'n, Employment Arbitration Rules \& 


\section{Consumer Protocols}

The AAA subsequently convened a broad-based advisory committee comprised of consumer advocates, providers of goods and services, representatives from state and federal agencies, academics, and others to consider developing due process guidelines for resolution of consumer disputes. ${ }^{199}$ Like its predecessor, the group was unable to agree as to whether pre-dispute arbitration agreements in consumer contracts should be enforced as a matter of policy, but it nevertheless successfully developed standards for arbitration and mediation processes associated with consumer contracts. ${ }^{200}$ Although it carries forward many of the elements of the Employment Protocol, the Consumer Due Process Protocol moves beyond the Employment Protocol in several important ways. It consists of fifteen principles, ${ }^{201}$ each of which embodies the foundational concept of "fundamentally-fair ADR process" expressed in Principle $1 .^{202}$ It admonishes sellers of goods or services to "undertake reasonable measures to provide [c]onsumers with full and accurate information regarding Consumer ADR Programs" and states that consumers should receive "all information necessary" regarding arbitration. ${ }^{203}$ It calls not only for independent and impartial neutrals, but also for administration of ADR programs by an "Independent ADR Institution,"204 which performs many key functions including

Mediation Procedures (2009), available at http://www.adr.org (highlight "Rules \& Procedures,” then click "Search Rules").

198. See JAMS, JAMS POLICY ON EMPLOYMENT ARBitRATION Minimum STANDARDS OF PROCEDURAL FAIRNESS (2009), available at http://www.jamsadr.com/files/Uploads/Documents/ JAMS-Rules/JAMS_Employment_Min_Stds-2009.pdf [hereinafter JAMS POLICY ON EMPLOYMENT ARBitration]. The Policy states that "JAMS supports the application of the 'Due Process Protocol for Mediation and Arbitration of Statutory Disputes Arising Out Of The Employment Relationship' to arbitrations based on condition-of-employment clauses" and, further, that the "JAMS Arbitration Rules and Procedures for Employment Disputes are consistent with the Due Process Protocol.” Id.; see also JAMS, JAMS EMPLOYMENT ARBitration Rules \& PROCEDURES (2009), available at http://www.jamsadr.com/files/Uploads/Documents/JAMS-Rules/JAMS_employment_arbitration_ rules-2009.pdf.

199. See Margaret M. Harding, The Limits of the Due Process Protocols, 19 OHIO ST. J. ON DisP. REsOL. 369, 405 (2004) (citing Thomas J. Stipanowich, Contract and Conflict Management, 2001 WIS. L. REV. 831, 896). The author was appointed Academic Reporter for the project and served as a facilitator of discussion among advisory committee members as well as the primary drafter for the Protocol and accompanying commentary.

200. See Consumer Protocol, supra note 33, Scope of the Consumer Due Process.

201. See generally id.

202. Id. Principle 1.

203. Id. Principle 2 (emphasis omitted).

204. Id. Principle 3. 
"establishing and maintaining standards for [n]eutrals."205 It also calls for processes to be conducted at reasonable cost, ${ }^{206}$ at a reasonably convenient location, ${ }^{207}$ and within a reasonable time. ${ }^{208}$ The Protocol also allows consumers, as well as companies, to retain the right to bring claims of the appropriate nature and amount in small claims court. ${ }^{209}$ The Consumer Due Process Protocol also goes well beyond the Employment Protocol in another respect: the basic principles are supplemented and explained by extensive Reporter's Comments discussing pertinent case law and contemporary standards governing arbitration and mediation, as well as practical suggestions for those implementing the Protocol. ${ }^{210}$

The Consumer Due Process Protocol became the template for the AAA Consumer-Related Disputes Supplementary Procedures. ${ }^{211}$ The Consumer Due Process Protocol strongly influenced the Healthcare Due Process Protocol, ${ }^{212}$ which mirrors many of its predecessors' key due process elements, such as: the right to a fundamentally fair process; ${ }^{213}$ access to information regarding the process; ${ }^{214}$ a neutral, independent, and qualified arbitrator; ${ }^{215}$ and a fair hearing conducted at a reasonable location and within a reasonable time. ${ }^{216}$ The Health Care Protocol was distinctive in taking the particularly significant step of acknowledging that "[i]n disputes involving patients, binding forms of dispute resolution

205. Id. Principle 4 (emphasis omitted).

206. Id. Principle 6.

207. Id. Principle 7.

208. Id. Principle 8

209. Id. Principle 5.

210. See, e.g., id. Principle 1, Reporter's Comments. The Reporter's Comments remain a singularly useful set of guideposts for addressing procedural fairness in arbitration.

211. See Am. ARbitration Ass'N, CONSUMER-Related Disputes SupPlementary Procedures (2005), available at http://www.adr.org (Search for "Consumer-Related Disputes Supplementary Procedures"). The AAA has the discretion to apply these supplementary procedures in disputes between individual consumers and businesses involving a product or service for personal or household use where the boilerplate arbitration agreements are non-negotiable. See id. at 2.

212. See Harding, supra note 199, at 407. The Commission responsible for the Healthcare Protocol was formed following the California Supreme Court's criticism of Kaiser Permanente's mandatory arbitration program in Engalla v. Permanente Medical Group, "at a time when serious questions were raised about the appropriateness of using arbitration for the resolution of health care disputes.” Id. at 407 \& n.219 (citing Margaret A. Jacobs, American Arbitration Association to Change Policy on Health Care, WALL ST. J., July 1, 1998, at B5).

213. HealthCARE Protocol, supra note 189, Principle 1.

214. Id. Principle 2.

215. Id. Principle 4-5.

216. Id. Principle 7-8. 
should be used only where the parties agree to do so after a dispute arises.",217

In the wake of recent controversies regarding the use of binding arbitration provisions in debt collection cases, the AAA convened a National Task Force on the Arbitration of Consumer Debt Collection Disputes to develop the Debt Collection Due Process Protocol as a supplement to the Consumer Due Process Protocol. ${ }^{218}$ Ten additional principles reflect the Task Force members' effort to make the arbitration process "substantially more accessible and easier for debtors to navigate than the current court process for debt collection litigation."219

JAMS developed its own Policy on Consumer Arbitrations Pursuant to Pre-Dispute Clauses Minimum Standards of Procedural Fairness. ${ }^{220}$ The JAMS Policy addresses most of the same procedural concerns as the Consumer Due Process Protocol but uses different language. ${ }^{221}$ JAMS

217. Id. Principle 3.

218. See DeBt Collection Protocol, supra note 190, at 2, 7.

219. Id. at 5. Additional due process protections in debt collection arbitrations include the following requirements: (1) “[a]rbitration should be commenced in a manner that provides substantial certainty that the debtor will receive the notice"; (2) notice "should be delivered in a manner that reflects an effort to communicate in a way that would normally result in a substantial certainty that the debtor will receive the communication"; (3) communication should be in plain English, or the primary language of the consumer where known; (4) demands for arbitration should include sufficient information to establish a claim; (5) "[p]rocedures should be implemented to identify claims that, at the time of filing, are beyond the applicable statute of limitations or are otherwise time-barred"; (6) the process for answering the demand "should be simplified"; (7) "[a]rbitrators should be appointed in a manner that enhances the perception of their neutrality"; and (8) participation in arbitration "should take ample advantage of technology and other means of allowing parties to participate in the arbitration process.” Id. at 7-11.

220. JAMS, JAMS POLICY ON CONSUMER ARBITRATIONS PURSUANT TO PRE-DisPUTE CLAUSES MiNiMUM STANDARDS OF PROCEDURAL FAIRNESS (2009), available at http://www.jamsadr.com/ consumer-arbitration/ [hereinafter JAMS POLICY ON CONSUMER ARBITRATIONS].

221. See id. The JAMS Policy on Consumer Arbitrations sets forth the following "minimum standards for arbitration procedures”:

1. The arbitration agreement must be reciprocally binding on all parties such that: A) if a consumer is required to arbitrate his or her claims or all claims of a certain type, the company is so bound; and, B) no party shall be precluded from seeking remedies in small claims court for disputes or claims within the scope of its jurisdiction.

2. The consumer must be given notice of the arbitration clause. Its existence, terms, conditions and implications must be clear.

3. Remedies that would otherwise be available to the consumer under applicable federal, state or local laws must remain available under the arbitration clause, unless the consumer retains the right to pursue the unavailable remedies in court.

4. The arbitrator(s) must be neutral and the consumer must have a reasonable opportunity to participate in the process of choosing the arbitrator(s).

5. The consumer must have a right to an in-person hearing in his or her hometown area.

6. The clause or procedures must not discourage the use of counsel. 
also included a specific requirement of mutuality—requiring both parties to be bound to arbitrate the same kinds of disputes ${ }^{222}$ — and a provision recognizing special limitations under California law on cost-shifting to consumers. $^{223}$

\section{Enforcing Protocols and Standards}

The Employment and Consumer Protocols and similar standards reflect the potential benefit that can come from providers' and stakeholder groups' cooperative efforts. Of course, written due process standards that are not translated into procedural rules for arbitration and subject to ongoing enforcement amount to nothing more than window dressing. When incorporated into specific arbitration procedures that are actively and effectively administered by an independent institution to ensure conformance with institutional requirements, however, there is evidence that such standards can enhance the real and perceived fairness and effectiveness of arbitration as an alternative to trial for consumers and employees. ${ }^{224}$

Notably, the AAA has made efforts to require companies that incorporate AAA procedures in consumer or employment contracts to comply with its procedures; ${ }^{225}$ JAMS has similar policies. ${ }^{226}$ The AAA's

7. With respect to the cost of the arbitration, when a consumer initiates arbitration against the company, the only fee required to be paid by the consumer is $\$ 250$, which is approximately equivalent to current Court filing fees. All other costs must be borne by the company including any remaining JAMS Case Management Fee and all professional fees for the arbitrator's services. When the company is the claiming party initiating an arbitration against the consumer, the company will be required to pay all costs associated with the arbitration.

8. In California, the arbitration provision may not require the consumer to pay the fees and costs incurred by the opposing party if the consumer does not prevail.

9. The arbitration provision must allow for the discovery or exchange of non-privileged information relevant to the dispute.

10. An Arbitrator's Award will consist of a written statement stating the disposition of each claim. The award will also provide a concise written statement of the essential findings and conclusions on which the award is based.

Id.

222. See id.

223. See id.

224. See Harding, supra note 199, at 402-04 (noting protection for employees from "one-sided arbitration clauses”).

225. See Am. Arbitration Ass'n, Fair Play: Perspectives From American Arbitration ASSOCIATION ON CONSUMER AND EMPLOYMENT ARBITRATION 33 (2003) (“[T]he AAA has adopted a policy that it may decline to offer its administrative services in consumer cases, and in employment cases arising from employer-promulgated ADR plans, where arbitration provisions do not comply 
Protocol-influenced procedures appear to have produced tangible positive results when effectively put into practice, as reflected in empirical studies of employment disputes conducted under the AAA. ${ }^{227}$ A recent independent investigation of AAA-administered consumer credit cases by a task force of Northwestern University's Searle Civil Justice Institute supports the conclusion that consumer-debtors prevailed more often in debt collection actions in AAA-administered debt collection arbitration than in court, and creditor recovery rates tended to be lower than, or comparable to, recovery rates in court. ${ }^{228}$

with due process protocols applicable to those caseloads. Employers and companies wishing to use AAA services for such cases are asked to obtain advance review by AAA of the program to determine compliance with the protocols.”); Christopher R. Drahozal \& Samantha Zyontz, Private Regulation of Consumer Arbitration 44-45 (U. Kan. Sch. of L., Working Paper No. 2011-4, 2011), available at http://ssrn.com/abstract=1904545 (discussing empirical findings on AAA's enforcement of the Consumer Due Process Protocol).

226. The JAMS Policy on Employment Arbitration addresses compliance with the policy in a practical way, as follows:

If JAMS becomes aware that an arbitration clause or procedure does not comply with the Minimum Standards, it will notify the employer of the Minimum Standards and inform the employer that the arbitration demand will not be accepted unless there is full compliance with those standards. In assessing whether the standards are met and whether to accept the arbitration assignment, JAMS, as the ADR provider, will limit its inquiry to a facial review of the clause or procedure. If a factual inquiry is required, for example, to determine compliance with Minimum Standards, it must be conducted by an arbitrator or court.

JAMS POLICY ON EMPLOYMENT ARBITRATION, supra note 198, at 4.

227. See, e.g., Lisa B. Bingham \& Shimon Sharaf, Employment Arbitration Before and After the Due Process Protocol for Mediation and Arbitration of Statutory Disputes Arising Out of Employment: Preliminary Evidence That Self-Regulation Makes a Difference, in ALTERNATIVE Dispute Resolution in the EMPLOYMENT ARENA: PROCEEdings OF NEW YoRK UNIVERSiTY 53RD ANNUAL CONFERENCE ON LABOR 303 (Samuel Estreicher \& David Sherwin eds., 2004) (identifying positive results after arbitration); Theodore Eisenberg \& Elizabeth Hill, Arbitration and Litigation of Employment Claims: An Empirical Comparison, DisP. RESOL. J., Nov. 2003/Jan. 2004, at 44, 53 (concluding that at least arbitrators "participating in AAA-sponsored arbitration" do "not act[] in a materially different fashion than in-court adjudicators"); see also Thomas J. Stipanowich, $A D R$ and the "Vanishing Trial": The Growth and Impact of "Alternative Dispute Resolution", $1 \mathrm{~J}$. OF EMPIRICAL LEGAL STUD. 843, 904-05 (2004) (citing empirical studies whose results reflect positive arbitration outcomes). But see Alexander J.S. Colvin, An Empirical Study of Employment Arbitration: Case Outcomes and Processes, 8 J. EMPIRICAL LEgAL STUD. 1, 21 (2011) ("Estimates of employee win rates and damage award amounts based on the AAA-CC filings data indicate that arbitration outcomes are generally less favorable to employees than those from employment litigation.”).

228. See Christopher R. Drahozal \& Samantha Zyontz, Creditor Claims in Arbitration and in Court, 7 HASTings Bus. L.J. 77, 102-03 (2011). 


\section{Due Process Standards in Proposed Legislation}

The Protocols prefigured and influenced proposals for statutory due process standards to govern consumer and employment arbitration under the FAA. ${ }^{229}$ One proposed set of standards, the Model Arbitration Act for Employment and Consumer Disputes, ${ }^{230}$ calls for the FAA to be amended to require, among other things:

1. "the right to representation by representatives of their own choosing at all stages of the proceeding";

2. "the right to all legal and equitable remedies that would have been available in a court of law";

3. a "time limit for filing a claim ... no shorter than the applicable statute of limitations";

4. arbitral "authority to order any and all discovery that he or she believes is needed and appropriate to render a fair decision;",231

5. "duty [of the arbitrator] to disclose any relationship that might reasonably constitute or be perceived as a conflict of interest";

6. "a [n]eutral [arbitrator] who is free of bias toward either party";

7. "equal rights in selecting the arbitrator";

8. "costs of arbitration, including the arbitrator's fee and any administration fees (but not legal fees) [to be borne by the company

229. See Stipanowich supra note 2, at 427-28. A number of cogent arguments have been advanced for legislated standards. Judicial decisions "fleshing out" the FAA and state arbitration statutes have resulted in a lack of uniformity in the enforcement of arbitration agreements, leaving companies, consumers, and employees uncertain as to what kinds of arbitration agreements will pass muster. See Schmitz, supra note 4, at 163. Legislated due process standards could afford a generally more effective framework for ensuring fundamental fairness in arbitration, providing significantly enhanced guidance for drafters of arbitration agreements as well as courts policing fairness in arbitration. Such standards would avoid the stark dilemma confronting consumers or employees who are required to wait until after an arbitration award has been rendered to raise issues of fundamental fairness. For example, a rule that sets effective limits on arbitration costs and fees in specified categories of contracts, such as a requirement that arbitration filing fees do not exceed otherwise applicable court filing fees, would prevent affected individuals from having to prove that arbitration-related costs are actually prohibitive. See Bales \& Eviston, supra note 38, at 18.

230. Model Arbitration Act (Proposed Draft 2010) (Submitted by Lew Maltby) (on file with author).

231. The proposed Act states: "Arbitrators are urged to use this authority in a manner that expedites the resolution of the dispute and discourages excessive costs or delay or unduly burdensome demands.” Id. 
and not the employee or consumer], except that the employee or consumer may be required to pay an amount equal to the filing fee in court in the appropriate jurisdiction" (with the voluntary option of paying up to half the expenses);

9. "fair and impartial administration”; “[a]rbitration rosters established and maintained on a non-discriminatory basis, diverse by gender, ethnicity, and background";

10. "[u]pon the request of either party... a written [arbitration award] ... provid[ing] a reasoned explanation of how the decision was reached"; and,

11. "[i]n the case of face-to-face proceedings, ... proceedings ... conducted at a location which is reasonably convenient to both parties with due consideration of their ability to travel and other pertinent circumstances.",232

Significantly, the Model Act also calls for express recognition of the availability of class actions for parties "under circumstances in which they are necessary for the parties to be able to vindicate their legal rights." ${ }^{233}$ To the extent this gives parties the option of pursuing collective or class-wide relief in court as an alternative to pursuing an individual action in arbitration, it is consistent with policy and practice in the realm of Financial Industry Regulatory Authority (FINRA) securities arbitration discussed below. ${ }^{234}$

\section{Better Business Bureau Standards and Procedures}

Once the Consumer Due Process Protocol was published, the Council of Better Business Bureaus (BBB) also announced a policy regarding "pre-dispute, binding arbitration clauses in consumer contracts" that call for arbitration pursuant to Better Business Bureau Rules of Arbitration. ${ }^{235}$ The BBB policy emphasizes "fair notice to the

232. Id. Lew Maltby proposed the Model Act as an alternative to the Arbitration Fairness Act, incorporating recommendations from Professor Amy J. Schmitz's article, Regulation Rash? Questioning the AFA's Approach for Protecting Arbitration Fairness, 28 BANKING \& FIN. SERVICES POL'y REP., Oct. 2009, at 16. See Sarah Rudolph Cole, On Babies and Bathwater: The Arbitration Fairness Act and the Supreme Court's Recent Arbitration Jurisprudence, 48 HoUS. L. REV. 457, 496-97 ("Professor Schmitz asserted that the need for some form of arbitration, particularly in the consumer context, must be balanced against the importance of avoiding 'needless protectionism.'”).

233. MODEL ARBITRATION ACT § I.12.

234. See infra text accompanying note 257.

235. See Better Business Bureaus Urge Fairness When Arbitration Is Used in Consumer 
consumer of the consequences of agreeing to arbitration" and the customer's formal and completely voluntary "acceptance of the arbitration clause.”236

The BBB Rules of Binding Arbitration (Pre-Dispute) include many of the same features included in AAA consumer arbitration rules. ${ }^{237}$ They are presented in a plain English format with prefatory questions and answers. ${ }^{238}$ It should be noted, however, that BBB's primary emphasis is not on binding arbitration under pre-dispute agreements, but focuses on programs like the Autoline program for resolving disputes under motor vehicle "lemon laws"-programs that afford consumers an abbreviated, informal arbitration system that results in an award that consumers may accept the award, or decline the award and proceed to trial. $^{239}$

Contracts, BBB (Mar. 26, 1998), http://www.bbb.org/us/article/better-business-bureaus-urgefairness-when-arbitration-is-used-in-consumer-contracts-179 [hereinafter Better Business Bureaus Urge Fairness]. The Council represents numerous local Better Business Bureaus throughout the United States and Canada. Local bureaus often assist in the resolution of disputes between a local business and its customers. See Louis Del Duca, Colin Rule \& Zbynek Loebl, Facilitating Expansion of Cross-Border E-Commerce-Developing a Global Online Dispute Resolution System (Lessons Derived From Existing ODR Systems-Work of The United Nations Commission on International Trade Law) 11-13 (Legal Studies Research Paper No. 25-2011, 2011).

236. Better Business Bureaus Urge Fairness, supra note 235. The policy requires the contract mandating BBB arbitration to:

- Identify the types of disputes that are covered by the arbitration clause;

- Identify the arbitration forum and provide a telephone number to contact for additional information about the forum;

- Disclose the nature and amount of any fees consumers may have to pay in connection with the filing or administration of their case; Advise consumers that, by signing the arbitration clause, they will not be able to go to court for that dispute;

- Advise consumers if strict application of law, rather than principles of fairness or equity, will be the basis for an arbitrator's decision; and,

- Require that the consumer separately sign the arbitration clause that must include both a signature line for the consumer to acknowledge that he or she agrees to the arbitration process and waives the right to sue in court over the dispute and a statement advising the consumer that he or she does not have to sign the arbitration clause, and that the consumer will not be committed by the clause unless he or she affirmatively acknowledges acceptance of the arbitration process.

Id.

237. Better Bus. Bureau, Rules of Arbitration [Binding]: Pre-Dispute (2010), available at http://www.bbb.org/us/storage/16/documents/dispute-resolution/Arbitration\%20Pre\%20Dispute\% 20395781.pdf.

238. Id. at $1-3$.

239. Interview with Rodney Davis, Vice President, Programs and Services, Better Business Bureau (Jan. 24, 2012) (notes on file with author). 


\section{Securities Arbitration Procedures and Program}

A relatively mature and robust system of arbitration for the resolution of investor-broker disputes that is in some respects a model for consumer dispute resolution has developed in a regulated environment. Ever since the Supreme Court decision in Shearson/American Express v. McMahon enforced arbitration of investor claims under section 10(b) of the Securities Exchange Act, ${ }^{240}$ investors have been required to arbitrate their disputes with brokerage firms. McMahon was founded on the expectation that the SEC would employ "expansive power to ensure the adequacy of the arbitration procedures employed by [securities self-regulatory organizations and] to oversee and to regulate the rules."241 Because it tends to be less costly and involve fewer procedural hurdles than going to court, securities arbitration has made it more feasible for investors to pursue and obtain recovery in many cases. ${ }^{242}$

With the SEC's oversight and approval, quasi-governmental but essentially private administrative bodies were established within self-

240. 482 U.S. 220, 238, 242 (1987) (holding that claims under the Racketeer Influenced Corrupt Organizations Act and the Securities and Exchange Act of 1934 are subject to arbitration).

241. Id. at 233-34.

242. One leading Los Angeles investor advocate explains:

Given the tremendous time and expense of pursuing any civil case in today's reduced staff, overworked and lengthy delay court system, I believe that almost every case that seeks actual damages of less than $\$ 1,000,000$ can be more efficiently pursued in arbitration using a fair forum. By the time one pursues a claim for less than a $\$ 1,000,000$ against, for instance, a large[,] well[-]financed public corporation, by successfully defending motions to dismiss based on the pleadings and thereafter engaging in discovery involving depositions, contention interrogatories, requests for admissions and successfully defending summary motions and fending off any appeals, the average civil plaintiff may well have his or her $\$ 1,000,000$ recovery significantly reduced by the expense of the court process. Arbitration of a claim for less than $\$ 1,000,000$ in a fair forum takes substantially less time and hence less expense because it involves significantly less discovery (most forums do not permit extensive pleading and motion practice and/or contention interrogatories and/or requests for admissions and/or summary motions). Finally, petitions to vacate an award, the only avenue of appealing an adverse arbitration award, are much more limited than typical appeals of a court issued judgment. In deciding petitions to vacate an arbitration award, appellate courts cannot review the facts de novo. Moreover, their review is limited to whether or not arbitrators manifestly disregard the law, acted outside the scope of their authority, engaged in fraud, failed to disclose a conflict of interest or unreasonably refused to grant a party an extension to continue the hearing. Consequently, petitions to vacate an arbitration award are rarely granted.

Email from Robert Uhl, investor attorney, Aidikoff, Uhl \& Bakhtiari, to author (Jan. 25, 2012) (on file with author). 
regulatory organizations-such as the New York Stock Exchange and the National Association of Securities Dealers-to administer arbitrations. $^{243}$ Today, virtually all investor-broker arbitration in the United States is conducted under FINRA's Dispute Resolution arm. ${ }^{244}$ The SEC, its advisory body, the Securities Industry Conference on Arbitration (SICA), ${ }^{245}$ and FINRA's own National Arbitration and Mediation Committee ${ }^{246}$ have actively promoted ongoing debate and discussion among investor-advocates and industry representatives, encouraging the continuing evolution of procedures that address public, as well as private, concerns. ${ }^{247}$

The continuing oversight and dialogue has proven critical in the development of a continuing series of pro-consumer modifications in securities arbitration procedures. ${ }^{248}$ For example, although there was a

243. See McMahon, 482 U.S. at 233-34 (stating that the Commission has broad authority to oversee arbitration procedures adopted by SROs and that the Commission has specifically approved the arbitration procedures of the New York Stock Exchange and the National Association of Securities Dealers).

244. Jill I. Gross, The End of Mandatory Securities Arbitration?, 30 PACE L. REV. 1174, 1177 \& n.22 (2010) (citing What is Dispute Resolution?, FINRA, http://www.publicjustice.net/Repository/ Files/What\%20is\%20Dispute\%20Resolution.pdf (last visited Apr. 12, 2012)). In 2007, NYSE and NASD consolidated to form FINRA, the Financial Industry Regulatory Authority. See id. at 1177 n.22 (citing Press Release, FINRA, NASD and NYSE Member Regulation Combine to Form the Financial Industry Regulatory Authority (July 30, 2007), available at http://www.finra.org/ Newsroom/NewsReleases/2007/P036329).

245. The author was a Public Member of SICA for six years and Chair of SICA for two years.

246. The National Arbitration and Mediation Committee is appointed by the Board of Directors of FINRA Dispute Resolution, has between ten and twenty-five members, and has the authority "to recommend rules, regulations, procedures and amendments relating to arbitration, mediation, and other dispute resolution matters to the Board. The NAMC shall also establish and maintain rosters of neutrals composed of persons from within and outside of the securities industry." FINRA, CODE of ARBitration Procedure FOR CUSTOMER Disputes § 12102(b) (2011) [hereinafter CUSTOMER CODE].

247. See Alicia J. Surdyk, Note, On the Continued Vitality of Securities Arbitration: Why Reform Efforts Must Not Preclude Predispute Arbitration Clauses, 54 N.Y.L. SCH. L. REV. 1131, 1137, 1149-50, 1152-53 (2009) (describing development of rule on reasoned awards as an exposition of the SRO-based regulatory process coupled with SEC oversight); see also Constantine N. Katsoris, Securities Arbitrators Do Not Grow on Trees, 14 FordHAM J. CoRP. \& FIN. L. 49, 54-58 (2008) (discussing the formation of SICA and development of the Uniform Code of Arbitration); Constantine N. Katsoris, Roadmap to Securities ADR, 11 ForDHAM J. CoRP. \& FIN. L. 413, 420-24 (2006); Stipanowich, supra note 227, at 910-12.

248. See SEC InVEstor Advisory Comm. PANel on SeC. Arb., FinAncial Industry REGULATORY AUTHORITY STATEMENT ON KEY ISSUES 1 (2010), available at http://www.sec.gov/ spotlight/invadvcomm/iacmeeting051710-finra.pdf [hereinafter FINRA STATEMENT] (describing FINRA's continuing review of its program to ensure procedural fairness and transparency). See generally NASD DispUte Resolution, THE ARBITRATION POlicy TASK ForCE RePORT-A REPORT CARD (2007), available at http://www.finra.org/web/groups/industry/@ip/@reg/@guide/ documents/industry/p036466.pdf (reporting developments in forum independence, financing, and administration; disclosures to investors; arbitrator selection, quality, and training; discovery; 
vociferous debate over whether securities investors should be able to obtain punitive damages in the wake of Mastrobuono $v$. Shearson Lehman Hutton, Inc., ${ }^{249}$ arbitrators do render punitive damages awards at rates comparable to judges and juries. ${ }^{250}$

Another example involves the makeup of arbitration tribunals. For many years a securities arbitration panel typically consisted of three arbitrators, a public chairperson, a public non-chairperson, and a representative of the securities industry, typically a broker or manager. ${ }^{251}$ Critics long complained that fairness in the process was compromised because a member of the securities industry had the authority to pass judgment on peers in the industry. ${ }^{252}$ Therefore, the FINRA rules were recently changed to give investors the right to have an arbitrated claim heard by three public arbitrators, although the investor still has the right to choose two public arbitrators and one industry arbitrator. ${ }^{253}$

Although securities arbitration procedures vary to some extent with the size of the claim, they have become increasingly similar to court procedures to ensure fundamental due process for investors. There is, for example, document discovery in securities arbitration, and FINRA requires parties to cooperate in the exchange of documents and information. ${ }^{254}$ FINRA also adopted a Discovery Guide that lists documents that parties are presumptively entitled to in different kinds of

mediation; simplified and standard case rules; punitive damages; and other matters).

249. 514 U.S. 52 (1995). The Court held that a New York decision prohibiting punitive damages by arbitrators did not preclude punitive damages in securities arbitrations subject to the FAA. Id. at $59,64$.

250. See FINRA STATEMENT, supra note 248, at 2 (“[A]rbitrators can and do award punitive damages in favor of investors."); Stephen J. Choi \& Theodore Eisenberg, Punitive Damages in Securities Arbitration: An Empirical Study, 39 J. LEgAL STUD. 497, 541 (2010) ("The substantial rate of punitive awards by securities arbitrators does not support the most extreme views of arbitrators as systematically hostile to investors. Nor are arbitrators randomly granting punitive damages.”).

251. See Gross, supra note 244, at 1180 n.36 (citing CUSTOMER CODE, supra note 246, R. 12402(b)).

252. See id. at 1185.

253. See FINRA STATEMENT, supra note 248, at 8-9, 19; CuSTOMER CODE, supra note 246, R. 12403(a). In a typical case, a party receives a list of thirty arbitrators divided into three groups; each party may strike up to four of the ten in each group and rank the remaining arbitrators. CUSTOMER CODE, supra note 246, R. 12403(c). In connection with this rank and strike procedure, FINRA provides each party with an arbitrator disclosure report that briefly summarizes the arbitrators' educational and work background, any accounts each have with any broker dealer, and a listing of every securities arbitration in which the arbitrator has participated. Id. RR. 12403(c), 12405. The arbitrators listed in the arbitration disclosure report are available for review by the parties. Id. R. 12405(c).

254. See Customer Code, supra note 246, R. 12505 ("The parties must cooperate to the fullest extent practicable in the exchange of documents and information to expedite the arbitration.”). 
cases. ${ }^{255}$ On the other hand, there are usually no pre-hearing depositions, pre-hearing substantive motions, contention interrogatories, or requests for admissions. ${ }^{256}$

Significantly, the FINRA rules make it clear that at the time disputes arise, investors retain the option of pursuing their claim individually through arbitration or pursuing a remedy through a class action, if that alternative is available in court. ${ }^{257}$ At a time when many companies are seeking to enforce class action waivers in connection with arbitration clauses, ${ }^{258}$ FINRA's commitment to retaining the right to collective action sets its program apart as a hallmark of fairness.

FINRA has tried to make its operations more transparent and to promote greater public understanding of and access to arbitration. ${ }^{259}$ FINRA regulates the content and form of pre-dispute arbitration provisions in investor agreements, requiring highlighted language explaining to investors the implications of the arbitration agreement and "prohibiting agreements that would limit the ability of any investor to file any claim in arbitration or that limits the power of arbitrators to make any award," including awards of punitive damages. ${ }^{260}$ It regulates fees to ensure that the securities industry bears the majority of administrative fees and waives hearing fees for investors who demonstrate financial hardship. ${ }^{261}$ FINRA assists investors in serving claims on brokerage firms. $^{262}$ It conducts hearings at any of seventy-two cities nearest the investor's residence. ${ }^{263}$ It provides expedited arbitration for senior or seriously ill parties. ${ }^{264}$

FINRA's website contains a variety of arbitration and mediation resources for investors, including roadmaps for filing a claim, understanding arbitration, and finding an attorney. ${ }^{265}$ FINRA provides

255. See id. R. 12506.

256. See, e.g., id. R. 12507(a)(1) ("Standard interrogatories are generally not permitted in arbitration.”); id. R. 12510 ("Depositions are strongly discouraged in arbitration.”).

257. See id. R. 12204.

258. See Stipanowich, supra note 2, at 371.

259. See FINRA STATEMENT, supra note 248 , at $1-2$.

260. See id. at 2; see also Order Approving a Proposed Rule Change Adopting FINRA Rules, 76 Fed. Reg. 5850 (Feb. 2, 2011) (approving FINRA Rule 2268).

261. See FINRA StAtement, supra note 248, at 3; Customer Code, supra note 246, RR. $12900-12903$.

262. See FINRA StATEMENT, supra note 248, at 3; Customer Code, supra note 246, R. 12302.

263. See FINRA STATEMENT, supra note 248, at 3; CUSTOMER CODE, supra note 246, R. 12213.

264. See FINRA STATEMENT, supra note 248, at 5; CUSTOMER CODE, supra note 246, R. 12207.

265. See Arbitration \& Mediation, FINRA, http://www.finra.org/ArbitrationAndMediation/ index.htm (last visited Apr. 12, 2012). 
monthly online updates of its arbitration and mediation case statistics. ${ }^{266}$ Through its Investor Education Foundation, FINRA funded a Guide to Securities Industry Disputes. ${ }^{267}$ "FINRA [also] supports several law school clinics that represent small investors who cannot afford to hire an attorney ....,268

The SEC oversees the practices and policies of the FINRA arbitration program, conducting audits and passing along changes to arbitration procedures; the General Accounting Office also conducts occasional reviews. ${ }^{269}$ There is also a well-established body of experienced lawyers who regularly represent investors in arbitration. ${ }^{270}$

\section{E. Principles for ADR Provider Organizations}

Experience with the implementation of the Due Process Protocols and the evolution of securities arbitration under the auspices of FINRA and the SEC have highlighted the critical role of organizations that provide arbitration and dispute resolution services. ${ }^{271}$ Increasing attention has been given to the role providers play in establishing a fair and open playing field for dispute resolution.

In 2002, a national ethics commission co-sponsored by the CPR Institute for Dispute Resolution ${ }^{272}$ and Georgetown University produced a wide-ranging set of Principles for ADR Provider Organizations. ${ }^{273}$ The Provider Principles set out a series of guidelines for entities providing dispute resolution services under the following rubrics: (1) "[q]uality and [c]ompetence of [s]ervices;" (2) "[i]nformation [r]egarding [s]ervices and [o]perations;" (3) "[f]airness and

266. See FINRA STATEMENT, supra note 248, at 1; Dispute Resolution Statistics, FINRA, http://www.finra.org/ArbitrationAndMediation/FINRADisputeResolution/AdditionalResources/Stati stics/index.htm (last visited Apr. 12, 2012).

267. See Investor's Guide to Securities Industry Disputes: How to Prevent AND Resolve Disputes With Your Broker (Jill Gross, Edward Pekarek \& Alice Oshins eds., 2011), available at http://www.finra.org/web/groups/foundation/@foundation/documents/foundation/ p119054.pdf.

268. See FINRA StATEMENT, supra note 248, at 7; Find an Attorney or Other Legal Representation, FINRA, http://www.finra.org/ArbitrationAndMediation/FINRADisputeResolution/ OptionsforInvestors/FindanAttorney/index.htm (last visited Apr. 7, 2012) (listing nineteen law schools with investor clinics, including Pepperdine).

269. See FINRA STATEMENT, supra note 248, at 9.

270. See id. at 8.

271. See generally Stipanowich, supra note 100.

272. The Institute is now named the International Institute for Conflict Prevention \& Resolution.

273. PRINCIPLES FOR PROVIDER ORganizations, supra note 43. The author was a member of the Commission and the Committee that developed the Principles. 
[i]mpartiality;" (4) “[a]ccessibility of [s]ervices;” (5) “[d]isclosure of [o]rganizational [c]onflicts of [i]nterest;" (6) "[c]omplaint and [g]rievance [m]echanisms;" (7) "[e]thical [g]uidelines: for neutrals and the organization; (8) "[f]alse or [m]isleading [c]ommunications;" and (9) protection of "[c]onfidentiality." 274 The Principles were a groundbreaking contribution to public discussions about the roles and responsibilities of provider organizations though not explicitly adopted by provider organizations. Subsequently, the AAA published its own Statement of Ethical Principles and internal ethics policy for its staff. ${ }^{275}$

\section{F. FTC Study on Debt Collection Adjudication}

In 2010, the FTC released an important report, entitled Repairing a Broken System: Protecting Consumers in Debt Collection Litigation and Arbitration. ${ }^{276}$ The report signals a singular effort to engender broadbased discussion about the concerns of consumer-debtors in public and private debt collection adjudication, and it is highly, but constructively, critical of both litigation and arbitration. Shedding useful light on the realm of debt collection arbitration, the report reinforces many frequently voiced concerns about consumer arbitration, including the lack of effective choice by consumers regarding binding arbitration, ${ }^{277}$ concerns about bias and appearance of bias on the part of arbitrators and arbitration forums, ${ }^{278}$ arbitration-related costs and the handling of costs, ${ }^{279}$ the opacity and difficulty of challenging arbitration awards ${ }^{280}$ and the lack of information regarding the performance of arbitration systems. ${ }^{281}$ The report also points out some of the special concerns of consumers as defendants, including notice of the commencement of arbitration and the rendition of awards. ${ }^{282}$ In many cases, the FTC offers useful observations or recommendations for addressing fairness concerns.

274. See generally id. Principles 1-9.

275. Am. Arbitration Ass'n, Statement of Ethical Principles for the American ARBitRATION AsSOCIATION, available at http://www.adr.org (search for "Statement of Ethical Principles").

276. FTC STUDY, supra note 20.

277. See id. at $42-46$.

278. See id. at $46-53$.

279. See id. at 60-62.

280. See id. at $62-67$.

281. See id. at $67-70$.

282. See id. at $55-59$. 


\section{G. Online Dispute Resolution}

The explosion in online communication and the burgeoning of ecommerce portends vast changes in our conceptions of human interaction, including the way we perceive, approach, and resolve conflict. $^{283}$ Online dispute resolution (ODR) holds the promise of "a fast, efficient, flexible and inexpensive mechanism for handling e-commerce disputes, both at the domestic level and across borders"284_-seemingly tailor-made for low-value, high-volume consumer disputes. In addition to reduce cycle time and costs in dispute resolution, ODR may also facilitate communication through a standardized communication system, which incorporates automatic translation tools. ${ }^{285}$ Systemic transparency and integrity may be enhanced by the use of "[m]inimum [c]ommon ODR [r]ules” and standards for ODR provider organizations and neutrals, centralized clearinghouses hosting electronic communications, and maintaining a central case database ${ }^{286}$ that might be useful in tracking program performance and providing key data to users. The Internet also makes possible innovative alternatives to traditional adjudication, such as eBay's "Community Court" system, which puts a buyer/seller dispute in front of a randomly selected panel of "jurors"-other experienced and well-regarded eBay users. ${ }^{287}$ Although the legal and practical challenges are immense, ${ }^{288}$ it must be assumed that online platforms will transform dispute resolution and, with it, our concepts of how to achieve fairness in adjudication.

\section{H. Empirical Research}

Another source of guidance regarding concepts of fairness is the growing body of research cataloging the experiences and perceptions of consumers and employees. The gathering of such empirical research has taken many forms and addressed a variety of important questions. For

\footnotetext{
283. See Del Duca, Rule \& Loebl, supra note 235, at 2.

284. Id. at 5.

285. See Zbynek Loebl, Creating a Multilingual Communication Standard for Cross-Border ODR, ODR \& CONSUMERS 2010 (Oct. 5, 2010), http://www.odrandconsumers2010.org/2010/10/05/ creating-a-multilingual-communication-standard-for-cross-border-odr/.

286. See Del Duca, Rule \& Loebl, supra note 235, at 16-18.

287. See Colin Rule \& Chittu Nagarajan, Leveraging the Wisdom of Crowds: The eBay Community Court and the Future of Online Dispute Resolution, ACRESOLUTION, Winter 2010, at 56, http://www.pmlink360.com/docs/acr.pdf.

288. See id. at 4-5 (discussing previous problems with online dispute resolution providers).
} 
example, the California Ethics Standards require providers to provide case statistics, which gather a variety of information on consumer and employment disputes, including amounts claimed and amounts awarded. ${ }^{289}$ Academics are conducting empirical research in the field of dispute resolution and have uncovered some perceptions people have of arbitration. Amy Schmitz, for example, has conducted studies that reveal that very few consumers are even aware that they have assented to the arbitration process simply by signing a contract. ${ }^{290}$ An empirical study conducted by Christopher Drahozal and Samantha Zyontz examined AAA-administered consumer cases; ${ }^{291}$ it determined that the AAA's review of arbitration clauses for Consumer Due Process Protocol compliance was effective, resulting in the refusal to administer a substantial number of cases and forcing the hand of some 150 businesses to waive or revise problematic clauses. ${ }^{292}$ Other studies focus on arbitral awards and remedies. Stephen Choi and Theodore Eisenberg, for example, have analyzed data on punitive damages awards in securities arbitration and compared these data to awards received in court, ${ }^{293}$ while Drahozal and Zyontz have compared dispositions of creditor claims in arbitration and in court. ${ }^{294}$ Jill Gross and Barbara Black have done empirical research on investor perceptions of securities arbitration. ${ }^{295}$ They found that investors had a much more negative perception of the arbitration process than other survey participants and investors often perceived arbitrators were biased; Gross and Black recommended that FINRA allow investors to choose an all-public panel, ${ }^{296}$ which FINRA subsequently did. ${ }^{297}$

Studies such as those outlined above will be helpful in assessing and defining what constitutes fairness within the arbitration framework. Conducting empirical research gives greater weight, accuracy, and neutrality to the conclusions we might make on what constitutes

\footnotetext{
289. See CAL. ETHICS STANDARDS, supra note 157, Standard 7(d).

290. See Schmitz, supra note 4, at 156-60 (describing the results of Professor Schmitz's study).

291. See Drahozal \& Zyontz, supra note 225.

292. Id. at $44-45$.

293. Choi \& Eisenberg, supra note 250, at 541.

294. See Drahozal \& Zyontz, supra note 228.

295. See Jill I. Gross \& Barbara Black, When Perception Changes Reality: An Empirical Study of Investors' Views of the Fairness of Securities Arbitration, 2008 J. DISP. RESOL. 349.

296. See id. at 400 .

297. See supra note 253 and accompanying text.
} 
fairness, ${ }^{298}$ and how to best cultivate it, by developing and implementing a rating system.

\section{Lessons of Experience}

The recent history of consumer and employment dispute resolution-including the development and application of pertinent standards of fairness in binding arbitration programs and related empirical findings-provides a useful foundation for constructing a rating system for such disputes. First, fairness considerations must begin with circumstances of contracting - the voluntariness of an individual's decision to arbitrate, ${ }^{299}$ his awareness of the implications of arbitrating instead of going to court, and access to information about the arbitration program. ${ }^{300}$ Second, procedural rules containing substantive due process standards mean little or nothing if they are not actively enforced and stringently administered, ${ }^{301}$ preferably by an independent and impartial third party. ${ }^{302}$ Third, concepts of fairness must be applied in a way that reflects the nature of the conflict. The needs of parties in high-value, low-volume disputes are likely to be very different from those in lowvalue, high-volume disputes, ${ }^{303}$ and the process needs and concerns of individual defendants differ to some extent from those of individual plaintiffs. ${ }^{304}$ Fourth, whether consumers and employees can participate in class or collective actions may have significant implications in some transactional settings. Some companies now include class action waivers in the context of arbitration agreements, while others do not-as illustrated by the general rule in securities arbitration giving investors the class action option. ${ }^{305}$ Fifth, many of our assumptions and expectations regarding the character and limitations of arbitration - and other dispute resolution approaches-are likely to be challenged or upset by the

\footnotetext{
298. But see Stipanowich, supra note 2, at 421-34 (discussing shortcomings of currently existing empirical research and recommendations for future research and due process protections).

299. See infra Part IV.B.1.

300. See infra Parts IV.B.2-3.

301. See infra Part IV.C.

302. See infra Part IV.D.

303. See Del Duca, Rule \& Loebl, supra note 235, at 26-27.

304. See supra text accompanying note 282.

305. See infra Part IV.E.8.
} 
development of sophisticated ODR platforms, ${ }^{306}$ which have the potential to address at least some of our concerns about fairness. ${ }^{307}$

\section{ELEMENTS OF AN ARBITRATION FAIRNESS INDEX FOR CONSUMER AND EMPLOYMENT ARBITRATION}

\section{A. Some General Observations-and Cautions}

A possible template for the Arbitration Fairness Index is depicted in Table A. ${ }^{308}$ The template is designed for an individual company's consumer arbitration program or employment arbitration program. Rated programs are assessed on each of twenty-three different program elements divided into five categories: (1) Meaningful Consent, Clarity, and Transparency; (2) Independent and Balanced Administration; (3) Quality and Suitability of Arbitrators; (4) Fair Hearings; and (5) Fair Outcomes. ${ }^{309}$ No attempt has been made to assign relative weights or point values to each element for reasons discussed below.

306. See supra Part III.G.

307. Another lesson from experience is that binding arbitration and other forms of binding adjudication are ill-suited to serve as first-tier remedial approaches. There should always be early opportunities for negotiation, mediation, or other appropriate forms of non-binding, third-party facilitation. See Commercial ARBITRATION at ITS BEST: SUCCESSFUl STRATEGIES FOR BUSINESS UsERS 5 (Thomas J. Stipanowich \& Peter H. Kaskell eds., 2001) [hereinafter CoMmercial ARBITRATION]. These concerns, however, are only tangentially related to the topic of this paper.

308. See infra Part IV.A.3.

309. See infra Part IV.A.3. 
Table A. Arbitration Fairness Index $(\mathbb{C}$

(for Binding Arbitration Programs under Pre-dispute Arbitration Agreements in Consumer and Employment Contracts)

\begin{tabular}{|c|c|c|c|c|c|c|}
\hline & ELEMENTS & Terrible & Poor & Fair & Good & $\begin{array}{l}\text { Very } \\
\text { Good }\end{array}$ \\
\hline \multirow{5}{*}{$\begin{array}{l}\text { Meaningful } \\
\text { Consent, } \\
\text { Clarity, and } \\
\text { Transparency }\end{array}$} & $\begin{array}{l}\text { Meaningful consent to } \\
\text { arbitrate }\end{array}$ & \multirow{23}{*}{\multicolumn{4}{|c|}{$\begin{array}{l}\text { (RELATIVE WEIGHTS OF RESPECTIV } \\
\text { ELEMENTS TO BE DETERMINED) }\end{array}$}} & \\
\hline & $\begin{array}{l}\text { Adequate notice and } \\
\text { disclosure }\end{array}$ & & & & & \\
\hline & $\begin{array}{l}\text { Clear guidance for } \\
\text { program users } \\
\text { ("roadmap”) and access } \\
\text { to helpline }\end{array}$ & & & & & \\
\hline & Ease of court oversight & & & & & \\
\hline & $\begin{array}{l}\text { Published program } \\
\text { statistics }\end{array}$ & & & & & \\
\hline \multirow{2}{*}{$\begin{array}{l}\text { Independent } \\
\text { and Balanced } \\
\text { Administration }\end{array}$} & $\begin{array}{l}\text { Independent and } \\
\text { impartial administration }\end{array}$ & & & & & \\
\hline & $\begin{array}{l}\text { Balanced input in rules } \\
\text { and policies }\end{array}$ & & & & & \\
\hline \multirow{5}{*}{$\begin{array}{l}\text { Quality and } \\
\text { Suitability of } \\
\text { Arbitrators }\end{array}$} & $\begin{array}{l}\text { Balanced input in roster } \\
\text { of arbitrators }\end{array}$ & & & & & \\
\hline & Diversity & & & & & \\
\hline & Experience and training & & & & & \\
\hline & $\begin{array}{l}\text { Disclosure and challenge } \\
\text { mechanism }\end{array}$ & & & & & \\
\hline & $\begin{array}{l}\text { Ethics standards and } \\
\text { complaint mechanism }\end{array}$ & & & & & \\
\hline \multirow[t]{8}{*}{ Fair Hearing } & $\begin{array}{l}\text { Reasonable costs and } \\
\text { fees }\end{array}$ & & & & & \\
\hline & Legal counsel & & & & & \\
\hline & $\begin{array}{l}\text { Reasonable hearing } \\
\text { location }\end{array}$ & & & & & \\
\hline & $\begin{array}{l}\text { Access to information } \\
\text { and discovery }\end{array}$ & & & & & \\
\hline & Limitations period & & & & & \\
\hline & Expeditious process & & & & & \\
\hline & Fair hearing & & & & & \\
\hline & $\begin{array}{l}\text { Availability of class } \\
\text { action }\end{array}$ & & & & & \\
\hline \multirow{3}{*}{$\begin{array}{l}\text { Fair Outcomes } \\
\text { (Awards and } \\
\text { Remedies) }\end{array}$} & $\begin{array}{l}\text { Access to remedies } \\
\text { available in court }\end{array}$ & & & & & \\
\hline & $\begin{array}{l}\text { Publication of reasoned } \\
\text { awards }\end{array}$ & & & & & \\
\hline & Outcomes & & & & & \\
\hline
\end{tabular}

(C) 2012 Thomas J. Stipanowich. All rights reserved. 


\section{Rated Programs}

There are several reasons why it makes sense to rate individual companies' arbitration programs - that is, an employer organization or a company selling consumer goods or services—as opposed to simply evaluating the rules and procedures of organizations that provide arbitration services_- "arbitration forums" or "provider organizations." First, some companies do not use the services of outside providers for their arbitration program, but administer their programs in-house or through a proprietary arm. ${ }^{310}$ More importantly, companies that do incorporate the rules of outside arbitration forums or provider organizations in their contracts may introduce-or attempt to introduce-customized modifications to the rules and procedures of the outside providers. ${ }^{311}$ These may, for example, impose special limitations on arbitral remedies and courses of action, such as class action waivers. ${ }^{312}$ Additionally, individual companies are in a position to exert considerable control over the amount and quality of information provided to consumers or employees about their arbitration programs. There may be situations in which these factors tend to discourage individuals from pressing claims at all, and thus, an outside provider will never receive demands for arbitration against the company. Only by examining individual arbitration programs in their totality-including the impact of specific contractual provisions and other surrounding circumstances - can we appreciate and evaluate fairness.

Of course, provider institutions are a critical element of most consumer and employment arbitration programs, and their active compliance will be critical in implementing the Index. Moreover, there is no reason why arbitration forums or provider organizations may not also be subject to a separate "arbitration forum/provider" rating system, and there are good reasons why they should be. Arbitration forums-many

310. See, e.g., Hooters of Am., Inc. v. Phillips, 173 F.3d 933, 936 (4th Cir. 1999) (describing employer-developed arbitration rules and procedures); Engalla v. Permanente Med. Grp., Inc., 938 P.2d 903, 909 (Cal. 1997) (same); see also Edward A. Dauer, Engalla's Legacy to Arbitration: Why Independent Administration Is Important, in AMERICAN ARBITRATION ASSOCIATION HANDBOOK ON COMMERCIAL ARBITRATION, supra note 100, at 149, 157-58 (noting that in the wake of Engalla, self-administration can make a finding of fraud more likely, and would undoubtedly receive a higher level of scrutiny from courts; thus, organizations wishing to avoid that eventuality should adopt an independently administered arbitration program).

311. See Schmitz, supra note 4, at 146, 148 (naming companies that include class waiver provisions and other provisions complying with the Consumer Due Process Protocol in their contracts).

312. See id. at 148, 152-53. 
of which exist to make a profit from the services they offer-are generally unregulated. ${ }^{313}$ As discussed below, they play a primary role in setting the table for consumer and employment arbitration through the development of rules and procedures, ${ }^{314}$ the maintenance of rosters of arbitrators, ${ }^{315}$ the administration of individual cases, ${ }^{316}$ the selection and handling of challenges to arbitrators, ${ }^{317}$ the establishment and implementation of fee structures, ${ }^{318}$ and the maintenance of case statistics. $^{319}$ Furthermore, the number of recognized independent arbitration forums is rather small, and it may be that by assembling information about and evaluating these key provider organizations we obviate the need to examine their rules, procedures, and administration every time a company incorporates their rules in a contract.

The present template is intended to evaluate only binding arbitration programs and not other forms of dispute resolution. It is expected that participation in the great majority of these programs will be triggered by pre-dispute arbitration provisions in consumer or individual employment contracts. Although a comprehensive dispute resolution program for consumers or employees often-and appropriately_includes hotlines or complaint services, as well as provisions for facilitated negotiation, mediation, and the like, ${ }^{320}$ the present template focuses on binding arbitration.

\section{Limitations of a Template}

Importantly, no single template may be wholly suitable for the broad range of consumer and employment arbitration programs. Because, as the Berlin Principles state, rankings must "be designed with due regard to their purpose,"321 several variations of the Index may be necessary. Even if the elements of the rating system remain the same, the assessment process is likely to be very different for an arbitration program aimed at

\footnotetext{
313. The FINRA securities arbitration program is an exception. See supra notes $240-57$ and accompanying text.

314. See infra Part IV.C.2.

315. See infra Part IV.D.1.

316. See infra Part IV.C.

317. See infra Part IV.D.5.

318. See infra Part IV.E.1.

319. See infra Part IV.F.1-2.

320. See, e.g., Thomas J. Stipanowich, 'Real Time' Strategies for Relational Conflict, 3 IBA MEDiation COMM. NEWSL. 6, 7 (2007) (discussing conflict management systems in the workplace).

321. RANKING SYSTEMS, supra note 107, at 52.
} 
relatively high-value employment disputes, as compared to a program designed for a high volume of low-value consumer disputes.

The identification of appropriate rating "elements" or "indicators" is another challenge, since some elements may be relevant and valid in one kind of consumer or employment arbitration scenario but not in others. Even with twenty-three separate program elements, our rating system does not include an element addressing the situation where a company offers specific incentives to induce agreements to arbitrate. It also does not reference "notice of filing of an arbitration demand" and "notice of award" - two elements that relate chiefly to process concerns like debt collection where consumers are defending claims and may be prejudiced by inadequate notice. ${ }^{322}$ Finally, it does not address the role of confidentiality, which may be an advantage or disadvantage to individuals in arbitration, depending on the circumstances. ${ }^{323}$

\section{Weighting}

The relative weight to be assigned to various elements of the Arbitration Fairness Index is likely to engender discussion and debate. The present template does not attempt to assign weights to various elements, leaving such questions to the deliberation and collective judgment of a broad-based advisory group, which hopefully will be charged with assisting in the development and implementation of the Arbitration Fairness Index. ${ }^{324}$

Another charge for an advisory group will be to award point values or ratings (e.g., “terrible,” "very good,” etc.) to a program depending on the way it addresses each of the respective fairness elements. This again, is a challenging prospect, but the task should be made easier by various guideposts, some of which are referenced in the following explanatory discussion. In any event, the effort to reach agreement on assigning

322. See FTC STUDY, supra note 20, at 55-59, 64-67 (discussing concerns about notice to debtors of pending arbitration and concerns about notice of the rendition of an arbitration award on a pending debt).

323. The Consumer Due Process Protocol calls for arbitrators to "make reasonable efforts to maintain the privacy of the hearing to the extent permitted by applicable law" and to "consider claims of privilege and confidentiality when addressing evidentiary issues." CONSUMER PROTOCOL, supra note 33, Principle 12(2). But see David v. O’Melveny \& Myers, 485 F.3d 1066, 1078-79 (9th Cir. 2007) (holding a confidentiality clause of an arbitration agreement unconscionable because it limited the ability of claimant to pursue claims and interview witnesses).

324. See infra Part V.B.2 (describing implementation of Index and need for broad-based advisory group). 
point values for a rating system should be immeasurably easier than getting Congress to agree on pertinent legislation!

In the following discussion regarding the Arbitration Fairness Index, many references will be made to "consumers" instead of the more cumbersome "consumers or employees," but it should be understood that the designation is intended to refer to either or both groups as the case may be.

\section{B. Meaningful Consent, Clarity, and Transparency}

\section{Meaningful Consent to Arbitrate}

At the heart of the debate over pre-dispute binding arbitration agreements is the issue of informed consent. For this reason, "meaningful consent to arbitrate" is the first element in the Arbitration Fairness Index. A 2010 FTC report on debt collection arbitration concluded that "consumers ... can make meaningful choices [about arbitration] only if they are aware of the arbitration provisions in contracts and have the ability to make choices regarding those provisions."325

Professor Schmitz's recent study supports the conclusion that many companies do not employ "robust assent mechanisms" with respect to arbitration provisions in consumer contracts, but they essentially rely on the fact that consumers will not be able to shop around for optimal terms. ${ }^{326}$ Her research also suggests that consumers are usually unaware of arbitration terms in contracts ${ }^{327}$ and often have the feeling that it is a waste of time to read form contract provisions "because they have no choice but to accept them." 328 Moreover, they tend to "have little or no understanding of arbitration," reinforcing general suspicions about the effectiveness of arbitration as a substitute for court. ${ }^{329}$ These concerns are reinforced by the 2010 FTC report. ${ }^{330}$ When consumers are brought

\footnotetext{
325. FTC STUDY, supra note 20, at 42.

326. Schmitz, supra note 4, at 149-50.

327. See id. at 167.

328. See id. at 152-54, 158-60 (discussing consumers' skepticism toward arbitration, consumers' trouble contacting company representatives or trying to negotiate specific terms, and consumers' relative passivity with respect to trying to negotiate arbitration terms).

329. Id. at 152.

330. See FTC Study, supra note 20, at 42-45; see also Linda J. Demaine \& Deborah R. Hensler, "Volunteering" to Arbitrate Through Predispute Arbitration Clauses: The Average Consumer's Experience, 67 LAW \& CONTEMP. PROBS. 55, 73 (2004) (“[T]his study provides little
} 
into an arbitration program under these circumstances, their perceptions of the legitimacy of the process and its outcomes are likely to be negatively affected. ${ }^{331}$

In order to achieve the maximum rating for "meaningful consent to arbitrate," a company would need to demonstrate that consumers were offered a clear choice whether to arbitrate or seek litigation. The choice needs to be affirmatively raised during the course of bargaining and made the subject of a discrete election; a less satisfactory (but in cases involving packaged consumer products, necessary) fallback would be a provision giving consumers an opportunity to "opt out" of arbitration after reading the terms of the contract. ${ }^{332}$

\section{Adequate Notice and Disclosure}

Again, meaningful assent requires an understanding of exactly what is given and received in choosing arbitration. Professor Schmitz's research indicates the difficulty consumer credit card or wireless customers have in getting details about arbitration provisions in their contracts. $^{333}$ The specific terms may not be available for inspection until after the contracting process. ${ }^{334}$ They tend to be buried in lengthy boilerplate, often in small-font typeface; they might be included in monthly "bill stuffers" or electronic formats accessible only through links that consumers might overlook. ${ }^{335}$ Arbitration clauses vary widely in "length, specificity and content." 336 At least some terms are confusing, and some except companies from limitations or requirements imposed on consumers. ${ }^{337}$ These realities emphasize the need for more effective notice and education regarding arbitration provisions. ${ }^{338}$

\footnotetext{
basis for believing that consumers are making informed decisions when they 'agree' to arbitrate in predispute arbitration clauses.”).

331. See Welsh, Making Deals, supra note 147, at 817-20.

332. See FTC STUDY, supra note 20, at 43-44 (discussing issues with “opt-out” approaches).

333. See Schmitz, supra note 4 , at $144-50$.

334. Id. at 145.

335. Id. at 149. Schmitz's discussions with consumers indicate, not surprisingly, that consumers "regularly throw out 'bill stuffers'” and tend to bypass posted contractual terms in e-contracts. Id. at 152.

336. Id. at 146 .

337. See id. at 148-49 (noting that consumers, but not companies, may be subject to time limitations on claims under some provisions).

338. The Consumer Due Process Protocol provides that at the time of contracting, the consumer should be given "clear and adequate" notice and "reasonable means" to obtain information about the ADR program. CONSUmer PROTOCOL, supra note 33, Principle 2 (emphasis omitted). According
} 
Consumers tend to want more information about arbitration and require fundamental guidance about what the arbitration alternative entails. ${ }^{339}$

Meaningful notice and disclosure should include prominent, easy-tounderstand statements about what arbitration alternatives entail ${ }^{340}$ and how arbitration differs from going to court. ${ }^{341}$ These should be presented in such a way as to ensure that consumers have an opportunity to read them before specifically accepting or declining arbitration. This information should be coupled with clear directions to obtain additional information if desired.

to the Reporter's Comments, consumers should be provided with, at minimum, "written information to explain the process.” Id. Principle 2, Reporter's Comments. Such information should include: (1) the "nature and purpose of the process"; (2) "an indication of whether or not the [c]onsumer has a choice regarding use of the process"; (3) "the role of parties and attorneys"; (4) "procedures for selection of [n]eutrals"; (5) "rules of conduct for [n]eutrals, and complaint procedures"; (6) "fees and expenses"; (7) "information regarding ADR program operation"; (8) "availability of special services"; and (9) "availability of alternatives to ADR, including small claims court." Id. Where binding arbitration is concerned, consumers should also be given a straightforward explanation of the differences between arbitration and litigation. Id. Principle 11; see also JAMS POLICY ON CONSUMER ARBITRATIONS, supra note 220 ("The consumer must be given notice of the arbitration clause.”).

339. See Schmitz, supra note 4, at 159-60.

340. See id. at 168-69. See, e.g., CONSUMER Protocol, supra note 33, Principle 2, Reporter's Comments ("All materials should be prepared in plain straightforward language. As a rule, such information should be in the same language as the principal contract for goods or services.”); id. Principle 11, Practical Suggestions (sample notice); see also FINRA STATEMENT, supra note 248, at 2 ("Predispute arbitration clauses in investor agreements must be highlighted and preceded by specified language stating, among other matters, that parties to a predispute arbitration agreement are giving up the right to sue each other in court; and that arbitration awards are generally final and binding. The contract also must contain a highlighted statement immediately preceding the signature line that states that the contract contains a predispute arbitration agreement, and the firm must give a copy of the agreement to the investor, who must acknowledge receiving it.”); JAMS POLICY ON CONSUMER ARBITRATIONS, supra note 220 (The "existence, terms, conditions and implications [of an arbitration clause] must be clear").

341. One example is provided in the Consumer Due Process Protocol. The language of a notice might read as follows:

This agreement provides that all disputes between you and [PROVIDER] will be resolved by BINDING ARBITRATION. You thus GIVE UP YOUR RIGHT TO GO TO COURT to assert or defend your rights under this contract (EXCEPT for matters that may be taken to SMALL CLAIMS COURT).... Your rights will be determined by a NEUTRAL ARBITRATOR and NOT a judge or jury.... You are entitled to a FAIR HEARING, BUT the arbitration procedures are SIMPLER AND MORE LIMITED THAN RULES APPLICABLE IN COURT. ... Arbitrator decisions are as enforceable as any court order and are subject to VERY LIMITED REVIEW BY A COURT.

CONSUMER PROTOCOL, supra note 33, Principle 11, Practical Suggestions. 


\section{Clear Guidance for Program Users (“Roadmap”) and Access to Helpline}

Information about an arbitration program would preferably involve simple online access to the arbitration agreement as well as any incorporated terms and procedures. ${ }^{342}$ All of these documents should be written in plain English, ${ }^{343}$ and if appropriate under the circumstances, should be available in multiple languages. ${ }^{344}$ Some organizations offer user-friendly explanations of the arbitration process in different forms. ${ }^{345}$ Ideally, there would also be access to a consumer website, helpline, or hotline to provide basic guidance about the arbitration program. ${ }^{346}$

\section{Ease of Court Oversight}

Delegation clauses-provisions authorizing arbitrators to address issues regarding the enforceability of the arbitration agreement-are ubiquitous in commercial contracts here and internationally. ${ }^{347}$ The Supreme Court, however, recently ruled that a broad delegation clause in an employment arbitration agreement is enforceable; this significantly limits the ability of consumers to get a court to consider defenses to an arbitration agreement prior to arbitration. ${ }^{348}$ Hence, resort to a court for redress is usually delayed until after an arbitration award is rendered and, at that stage, is subject to rather stringent limits on the grounds for judicial vacatur of award. ${ }^{349}$ These strictures are exacerbated by the fact that an arbitration award may contain no rationale in support of the announced result.

With these realities in mind, "ease of court oversight" is included as an element of the Index. The presence and breadth of clauses delegating

342. See Schmitz, supra note 4, at 169

343. See, e.g., Consumer Protocol, supra note 33, Principle 2, Reporter's Comments (“All materials should be prepared in plain straightforward language.”).

344. See, e.g., DeBt Collection Protocol, supra note 190, Principle 4 (stating that efforts should be made to communicate in the primary language of the respondent).

345. For example, FINRA provides online assistance for claimants. See, e.g., FINRA, UNIFORM FORMS GUIDE (2011), available at http:/www.finra.org/web/groups/arbitrationmediation/@arbmed/ @tools/documents/arbmed/p007954.pdf.

346. See, e.g., id. at 6 (listing FINRA's hotline number).

347. See Stipanowich, supra note 2, at 367, 370 (stating that delegation provisions will "be[come] ubiquitous in employment and consumer contracts").

348. See id. at 364-70 (discussing Rent-A-Center and its implications).

349. See id. at 368 (stating that courts “accord arbitration discretion significant deference”). 
authority to arbitrators that would eliminate the possibility of front-end judicial policing should reduce a program's rating. If arbitration rules do not require arbitrators to support their awards with basic rationales and clearly indicate the disposition of claims, including awards of attorney fees, interest, and punitive damages, then the rules should receive a lower rating in this category. ${ }^{350}$

\section{Published Program Statistics}

When it comes to arbitration, another dimension of understanding comes through familiarity with the system. One would expect regular users to have more accurate expectations about the likelihood of success in arbitration and knowledge of, or experience with, particular arbitrators. ${ }^{351}$ Thanks to the California Ethics Standards, some major provider organizations have furnished various data on individual consumer and employment arbitrations under their operation, ${ }^{352}$ although the data are not summarized. FINRA publishes monthly updates of case statistics on its website. ${ }^{353}$ Preferably, consumers should have access to data that provide summaries that reflect consumer win rates, as well as basic information regarding individual arbitrators such as the business parties and law firms that appeared before them and summaries of their prior awards. ${ }^{354}$

\section{Independent and Balanced Administration}

1. Independent and Impartial Administration

Fairness in binding arbitration programs for consumers cannot be achieved solely through statutes, court decisions, regulators, or

350. See Surdyk, supra note 247, at 1149-50, 1152-53 (describing development of rule on reasoned arbitration awards as an exposition of the current SRO-based regulatory process coupled with SEC oversight).

351. See Colvin, supra note 227, at 11-16 (providing a nuanced discussion of the repeat-player dynamic in employment arbitration); Christopher R. Drahozal \& Samantha Zyontz, An Empirical Study of AAA Consumer Arbitrations, 25 OHIO ST. J. ON DisP. Resol. 843, 857-62, 908-16 (2010) (discussing possible reasons for the repeat-player effect and implications of various studies, including the authors' own analysis of AAA consumer data).

352. See, e.g., Consumer Arbitration Statistics, supra note 173; JAMS Disclosures, supra note 173.

353. Dispute Resolution Statistics, supra note 266.

354. The California Ethics Standards seek data of this kind. See supra notes 168-73 and accompanying text. 
arbitrators. There is always the need for a mechanism for the creation and administration of the arbitration program. How can arbitration proceed without fair and appropriate procedures, tailored for specific transactional settings, and how are these developed? Realistically, how does a consumer choose an arbitrator without an accessible, carefully developed roster of candidates? Who creates the roster and sets the criteria for inclusion, and will there be a voice for consumers in the process? Who screens potential arbitrators for possible conflicts of interest and addresses challenges to their appointment? Who handles complaints about arbitrators' performance? Who handles the payment of their fees? Who, if anyone, maintains records of the program, monitors and evaluates the operation of the program, and undertakes appropriate changes? The answers to these questions are critical to the consumer's experience in arbitration. The character and commitment to fairness of the institution "behind" the arbitration process should be of paramount concern. ${ }^{355}$

The pervasive role of such institutions is reflected in the Employment Due Process Protocol, ${ }^{356}$ which repeatedly makes references to a "designating agency" as a part of the implementation of a fair arbitration program. ${ }^{357}$ Although one might intuit as much, the

\footnotetext{
355. Stipanowich, supra note 100 , at 47.

Some "provider organizations," such as JAMS, exist to make a profit, while others (like AAA) claim public interest priorities; all compete in the burgeoning and increasingly saturated marketplace of private dispute resolution, usually with minimal regulatory oversight. Some span continents, while others serve regional or local markets and needs. Some only compile and publish lists of arbitrators and mediators ("neutrals"), some train or purport to "certify"; others act as appointing authorities-helping parties to select arbitrators or mediators for particular cases; still others offer a broader spectrum of administrative support for parties in conflict.
}

Id.

356. EMPLOYMENT PROTOCOL, supra note 187.

357. The Employment Protocol calls for arbitrators to

[b]e bound by applicable agreements, statutes, regulations and rules of procedure of the designating agency, including the authority to determine the time and place of the hearing, permit reasonable discovery, issue subpoenas, decide arbitrability issues, preserve order and privacy in the hearings, rule on evidentiary matters, determine the close of the hearing and procedures for post-hearing submissions, and issue an award resolving the submitted dispute.

Id. at 4 (emphasis added). A separate section calls for training "administered perhaps by the designating agency, such as the AAA, at various locations throughout the country." Id. at 3 (emphasis added). Another provision states that "[u]pon request of the parties, the designating agency should utilize a list procedure such as that of the AAA or select a panel composed of an odd number of mediators and arbitrators from its roster or pool." Id. (emphasis added). The Protocol also acknowledges the potential role of designating agencies in "negotiating the parties' share of costs and collecting [arbitral fees so as to possibly] reduce the bias potential of disparate 
Employment Protocol did not make clear whether the designating agency needed to be independent and impartial.

The establishment of ADR programs within, or on behalf of, particular companies, tied to provisions in standardized employment or consumer contracts that require employees or customers to arbitrate, raised special concerns about the independence and impartiality of those rendering dispute resolution services and the fairness of dispute resolution in general. ${ }^{358}$ Such programs blossomed in the wake of a string of U.S. Supreme Court decisions broadly enforcing contractual arbitration agreements and requiring parties to arbitrate virtually the entire spectrum of civil claims, including statute-based actions. ${ }^{359}$

Concerns are greatest in the context of a private adjudicative system set up and administered by companies. Some time ago, the California Supreme Court denied enforcement to an arbitration agreement in the consumer contract of the nation's largest HMO on the basis of false representations to the public about the speed of its internallyadministered claims arbitration process; ${ }^{360}$ the HMO subsequently junked its in-house program and established an "outside" process. ${ }^{361}$ In another highly publicized decision, the Fourth Circuit Court of Appeals struck down an employment arbitration program run by, and heavily skewed toward, an employer-Hooters. ${ }^{362}$

Even with outside providers, the presence of an ongoing service relationship with a corporate entity raises red flags when other parties are not repeatedly engaged with the provider. Providers should recognize that a close connection between a provider and company may be a source of concern to the incidental user-the employee or customer who is

contributions by forwarding payment to the mediator and/or arbitrator without disclosing the parties' share therein." Id. at 5.

358. See Jay Folberg et AL., Resolving Disputes: Theory, Practice and LaW 691-731 (2d ed. 2010). See generally Stipanowich, supra note 199, at 888-916 (arguing for greater accountability in the ADR context).

359. See FolBERG ET AL., supra note 358, at 695-708.

360. Engalla v. Permanente Med. Grp., Inc., 938 P.2d 903, 922 (Cal. 1997).

361. See Blue Ribbon Advisory Panel on Kaiser Permanente Arbitration, The Kaiser PERMANENTE ARBitration SYSTEM: A REVIEW AND RECOMMENDATIONS FOR IMPROVEMENT 3, 31-45 (1998), available at http://www.oia-kaiserarb.com/oia/Forms/BRP\%20Report.pdf [hereinafter KAISER PERMANENTE ARBITRATION SYSTEM] (giving recommendations to establish the "outside" process in response to Engalla); see also Office of the Independent Administrator, OIA, http://www.oia-kaiserarb.com (last visited Apr. 12, 2012) ("The OIA administers arbitrations between Kaiser Foundation Health Plan, Inc. and its California health plan members. The OIA is a neutral, independent office. We are not part of Kaiser.”).

362. See Hooters of Am., Inc. v. Phillips, 173 F.3d 933, 938-40 (4th Cir. 1999) (discussing the biased provisions and holding that promulgation of such rules breached the employment contract). 
drawn into an ADR process by a pre-dispute ADR clause in a companydrafted contract. The highly visible action by the Minnesota attorney general against the National Arbitration Forum (NAF), alleging fraud and deceptive practices and resulting in a settlement under which NAF ceased administering consumer credit arbitration disputes, ${ }^{363}$ highlighted concerns about potential conflicts of interest stemming from relationships between private ADR provider institutions and those that regularly use their services. ${ }^{364}$ Similar concerns are reflected in Walker v. Ryan's Family Steak Houses, Inc., in which a federal district court found that the arbitration provider was responsible for at least three instances of "structural bias.",365

The broad-based national groups that developed due process protocols for consumer and health care disputes each separately concluded that contractually mandated, private conflict resolution should be independently administered. ${ }^{366}$ The Consumer Due Process Protocol states:

If participation in ... arbitration is mandatory, the procedure should be administered by an Independent ADR Institution. Administrative services should include the maintenance of a panel of prospective Neutrals, facilitation of Neutral selection, collection and distribution of Neutral's fees and expenses, oversight and implementation of ADR rules and procedures, and monitoring of Neutral qualifications, performance, and adherence to pertinent rules, procedures and ethical standards. $^{367}$

The role of the Independent ADR Institution is inextricably intertwined throughout the Consumer Due Process Protocol.

In a similar vein, the California Ethics Standards call upon arbitration provider organizations as well as arbitrators to make disclosures relating to possible conflicts of interest. ${ }^{368}$ Concerns about independence and impartiality are also reflected in the 2002 CPRGeorgetown Principles for ADR Provider Organizations. ${ }^{369}$

363. See Consent Judgment, Minnesota v. Nat'l Arb. Forum, Inc., No. 27-cv-09-18550 (Minn. Dist. Ct. July 17, 2009), available at http://pubcit.typepad.com/files/nafconsentdecree.pdf.

364. See Bales \& Eviston, supra note 38, at 12-13 (discussing potential conflicts)

365. 289 F. Supp. 2d 916, 923-24 (M.D. Tenn. 2003), aff'd 400 F.3d 370 (6th Cir. 2005).

366. See Consumer Protocol, supra note 33, Principle 3; Healthcare Protocol, supra note 189, Principle 4.

367. Consumer Protocol, supra note 33, Principle 3(2) (emphasis omitted).

368. See CAL. ETHICS STANDARDS, supra note 157, Standards 7-8.

369. See Principles for Provider ORganizations, supra note 43, Principles 3, 5, 7. 
The independence and impartiality of the arbitration provider should be an element of any rating system for consumer arbitration programs. ${ }^{370}$

\section{Balanced Input in Rules and Policies}

The development of the Protocols and the evolution of securities arbitration procedures exemplify the importance of having rules and policies developed and refined by a balanced advisory group representing the interests of all stakeholders, with particular emphasis on the effective representation of consumers or employees. ${ }^{371}$ The group

\footnotetext{
A further word is in order about provider accountability. Like the arbitrators who act under their imprimatur, providers are cloaked with quasi-judicial immunity to preserve the integrity of the arbitration process. See Butz v. Economou, 438 U.S. 478, 511-12 (1978) (extending quasi-judicial immunity to non-judicial officials is properly based on the "functional comparability" of the individual's acts and judgments to the acts and judgments of judges (citing Imbler v. Pachtman, 424 U.S. 409, 423 n.20 (1976))); Corey v. NYSE, 691 F.2d 1205, 1209, 1211 (6th Cir. 1982) (same). The principle of arbitral immunity is well established in the courts, along with a penumbra of immunity for providers. See, e.g., Corey, 691 F.2d at 1211 (extending immunity to providers); see also New Eng. Cleaning Servs., Inc. v. Am. Arbitration Ass'n, 199 F.3d 542, 544-46 (1st Cir. 1999) (extending immunity to providers for liability arising from arbitrator selection, billing, scheduling, and other administrative acts); Honn v. Nat'l Ass'n of Sec. Dealers, Inc., 182 F.3d 1014, 1017 (8th Cir. 1999) (extending arbitral immunity to organizations that sponsor arbitrations); Hawkins v. Nat'l Ass'n of Sec. Dealers, Inc., 149 F.3d 330, 332 (5th Cir. 1998) (extending arbitral immunity to NASD for contractual arbitration proceedings); Olson v. Nat'l Ass'n of Sec. Dealers, Inc., 85 F.3d 381, 382-83 (8th Cir. 1996) (holding that NASD is immune from liability for a tainted arbitration proceeding). A decade ago, the revision of the Uniform Arbitration Act reignited debate over the scope of arbitral immunity, including institutional immunity. The Revised Uniform Arbitration Act states: "An arbitrator or an arbitration organization acting in that capacity is immune from civil liability to the same extent as a judge of a court of this State acting in a judicial capacity." UNIF. ARBITRATION ACT § 14(a) (amended 2000). Scholars continue to raise questions regarding the scope of arbitral immunity. See, e.g., Maureen A. Weston, Reexamining Arbitral Immunity in an Age of Mandatory and Professional Arbitration, 88 MiNN. L. REV. 449 (2004) (examining per se immunity doctrines for arbitrators and arbitration providers and suggesting remedies for arbitral failures). The existence of provider immunity raises the question of alternative ways to ensure accountability. See id. at $460,511-16$.

370. Some companies allow consumers to choose among two or more providers. See, e.g., Demaine \& Hensler, supra note 330, at 67. Given sufficient information to make effective choices, this affords consumers additional flexibility.

371. See Lisa B. Bingham et al., Evaluating Dispute System Design, in DiSPUTE SYSTEM DESign: PREVENTING, MANAGING, AND RESOLVING CoNFLICT (forthcoming 2012) (discussing level of self-determination or control of disputants in process, outcome, and dispute systems design). The Consumer Due Process Protocol contains the following "Practical Suggestion" pertaining to the establishment of ADR policies and procedures:

A helpful model for program administrators is the User Advisory Committee now being utilized by the AAA to establish procedures and policies for ADR in the areas of employment, construction, health care, and other transactional settings. Such entities should provide a forum in which representatives of Consumers and Providers [of goods and services] cooperate in the development and implementation of policies and procedures governing an ADR program, including selection of Neutrals.
} 
should include individuals with pertinent advocacy and arbitration experience.

Of course, the development of rules and policies is an ongoing process that requires a commitment to continuous stakeholder input. One previously discussed illustration of process evolution through robust discussion and debate involved the joint initiatives of FINRA's (previously NASD's) advisory committee and the Securities Industry Conference on Arbitration-two groups bringing together investor and brokerage industry advocates to develop guidelines or templates for discovery, including "presumptively discoverable" documents for different kinds of investor claims. ${ }^{372}$

\section{Quality and Suitability of Arbitrators}

\section{Balanced Input in Roster of Arbitrators}

Of all the ways in which provider organizations may affect the user's experience, none is as likely to be as critical as the organizations' role in screening and facilitating the selection of neutrals. Providers often assist in the arbitrator selection process by identifying prospective neutrals based on criteria provided by the parties and, in some cases, making the appointment. Moreover, providers may be empowered to consider and rule upon challenges to an appointee. At the conclusion of the proceeding, some providers furnish a mechanism for evaluating the neutral and the process.

Establishing and maintaining a roster or "pool" of neutrals is usually a core competency of providers - a need that is first and foremost in the minds of those seeking dispute resolution services. ${ }^{373}$ In each

\footnotetext{
CONSUMER PRotocol, supra note 33, Principle 3, Practical Suggestions (citation omitted) (citing Kaiser PERMANENTE Arbitration System, supra note 361, at 32).

372. See supra text accompanying note 254 .

373. The Reporter's Comments for the Consumer Due Process Protocol state:

The most critical element in ADR quality control is the establishment and maintenance of standards of competence for Neutrals [arbitrators and mediators] within the program. "Competence" refers to "the acquisition of skills, knowledge and ... other attributes" deemed necessary to assist others in resolving disputes in a particular setting....

While ensuring the competence of Neutrals is always important, it is particularly "critical in contexts when party choice over the process, program or neutral is limited," a reality of many Consumer ADR programs.

Consumer Protocol, supra note 33, Principle 4, Reporter's Comments (citations omitted) (quoting SPIDR, supra note 33, at 5-6).
} 
transactional setting, there are special concerns that favor an evenhanded mechanism for identifying potential arbitrators with appropriate credentials. For example, concerns have been raised about the supposed built-in biases of employment arbitrators actively engaged in practice on behalf of employers or employees. ${ }^{374}$ A common method for developing pools of such candidates is the creation of an advisory committee comprised of experienced users. ${ }^{375}$

The extensive Reporter's Comments to the Consumer Due Process Protocol state, among other things, that the "qualifications [of arbitrators and mediators] are best established by joint efforts of concerned 'stakeholders." "376 They cite various sources recognizing the importance of giving consumers "a voice in establishing and maintaining standards of competence and quality in ADR programs.”377

\section{Diversity}

The Employment Due Process Protocol calls for the maintenance of "a roster of available mediators and arbitrators [to] be established on a non-discriminatory basis, diverse by gender, ethnicity, background, experience, etc. to satisfy the parties that their interest and objectives will be respected and fully considered." ${ }^{378}$ Like other disputants, consumers seek assurance that decision makers are, among other things, giving adequate consideration to their presentations and evidence. ${ }^{379}$ Recent empirical studies examining public and private arbitration support the conclusion that the background and gender of decision makers tend to affect their approach to disputes. ${ }^{380}$ It is likely that a consumer would

374. See Bales \& Eviston, supra note 38, at 13 ("The most flagrant problem with arbitral selection is when an employer reserves to itself, in the arbitration contract, exclusive or inordinate control in selecting the arbitrator or creating the pool of arbitrators.”).

375. See supra note 371 and accompanying text.

376. Consumer Protocol, supra note 33, Principle 4, Reporter's Comments (citing KAISER Permanente Arbitration System, supra note 361, at 35-36). The Consumer Due Process Protocol also states: “All parties are entitled to competent, qualified Neutrals. Independent ADR Institutions are responsible for establishing and maintaining standards for Neutrals in ADR Programs they administer.” Id.

377. See id.

378. EMPLOYMENT PROTOCOL, supra note 187, at 3.

379. Allen Lind, Procedural Justice, Disputing, and Reactions to Legal Authorities, in EVERydAy PRACTICES AND TROUBle CASES 177, 183 (Austin Sarat et al. eds., 1998).

380. See generally Pat K. Chew \& Robert E. Kelley, Myth of the Colorblind Judge: An Empirical Analysis of Racial Harassment Cases, 86 WASH. U. L. REV. 1117 (2009) (finding judges' race significantly affects outcomes in federal cases). 
discount the legitimacy of a tribunal with which he does not in some way identify. ${ }^{381}$ Today, considerable effort is being devoted to promote diversity on rosters of arbitrators and mediators. ${ }^{382}$

\section{Experience and Training}

A rating system should also take into account the appropriateness of the experiential backgrounds of arbitrators in the program and the relative "balance of backgrounds" on individual panels. Among business users, arbitrator expertise is often a prized hallmark of arbitration. ${ }^{383}$ To consumers, however, "technical or professional experience often carries with it the perception if not the reality of bias." 384 From the consumer's perspective, an arbitrator who comes from the same commercial or professional background as the company on the other side of the dispute "may not be the ideal judge." ${ }^{385}$ In response to such concerns, BBB Auto Line panels are comprised of one or two public arbitrators and possibly a technical expert. ${ }^{386}$ A similar arrangement has for years been the norm in securities arbitrations. But after years of concern by investor-advocates about the influence of industry representatives, FINRA recently gave investors the option to have a three-member tribunal comprised of arbitrators without experience in the securities industry. ${ }^{387}$ In the future, any involvement by "industry" arbitrators will be solely at the election of investors. At the same time, it may be highly desirable for all arbitrators, whatever their background, to have training in key legal or procedural fundamentals. $^{388}$

381. See supra notes 252-53 and accompanying text.

382. See Joshua W. Martin, The Next Level: Promoting Diversity in the ADR Arena, 15 METROPOLitAn CORP. Couns. 69, 69 (2007) (describing two practitioners' efforts to improve diversity)

383. See COMmercial ARBitration, supra note 307, at 77-78.

384. Consumer Protocol, supra note 33, Principle 4, Reporter's Comments.

385. Id.

386. See Description and Rules-All States Except California, BBB, http://www.bbb.org/us/ auto-line/us-process/\#eight (last visited Apr. 12, 2012) (providing information about the BBB AUTO LINE).

387. See supra text accompanying notes 253.

388. The Comments to the Consumer Due Process Protocol state:

An Independent ADR Institution's responsibility for the qualifications of Neutrals in a particular Consumer ADR program dictates the development of an appropriate training program. Ideally, the training should include a mentoring program with experienced Neutrals as well as coverage of applicable principles of Consumer law. Successful completion of such training should be reflected in the information on prospective Neutrals furnished to the parties prior to selection. 


\section{Disclosure and Challenge Mechanism}

Just as the ability to effectively make a choice about arbitration presumes adequate information about the process, its workings, and its implications, effective choices regarding decision makers presume sufficient information regarding their background, affiliations, and connections to the parties, and the subject matter of the dispute. ${ }^{389}$ An effective procedure for full, timely disclosure of potential conflicts of interest by would-be arbitrators, coupled with the ability to challenge and have nominees administratively deselected for cause, is a critical element of due process in any form of arbitration. ${ }^{390}$ At a time when there is considerable sensitivity about the implications of relationships between arbitrators and "repeat players" in consumer arbitration programs, disclosures of both past arbitration experiences in which the same company was a party and the results are significant facts. ${ }^{391}$

\section{Ethics Standards and Complaint Mechanism}

In light of the special trust vested in arbitrators as what one might call "fiduciaries of conflict resolution," some arbitration providers have adopted codes of ethics for arbitrators. ${ }^{392}$ The CPR-Georgetown

Consumer Protocol, supra note 33, Principle 4, Reporter's Comments (citations omitted) (citing Mark E. Budnitz, Arbitration of Disputes Between Consumers and Financial Institutions: A Serious Threat to Consumer Protection, 10 OHIO ST. J. ON DISP. RESOL. 267, 315 (1995)).

389. See COMMERCial ARBitration, supra note 307, at 73-75 (discussing importance of arbitrator disclosure of potential conflicts of interest in arbitrator selection process).

390. The Consumer Due Process Protocol includes the following policy respecting disclosure and challenge:

Beginning at the time of appointment, Neutrals should be required to disclose to the Independent ADR Institution any circumstance likely to affect impartiality, including any bias or financial or personal interest which might affect the result of the ADR proceeding, or any past or present relationship or experience with the parties or their representatives, including past ADR experiences. The Independent ADR Institution should communicate any such information to the parties and other Neutrals, if any. Upon objection of a party to continued service of the Neutral, the Independent ADR Institution should determine whether the Neutral should be disqualified and should inform the parties of its decision. The disclosure obligation of the Neutral and procedure for disqualification should continue throughout the period of appointment.

CONSUMER PROTOCOL, supra note 33, Principle 3 (emphasis omitted).

391. These concerns underlie the California Ethics Standards. See supra text accompanying notes $168-73$.

392. See, e.g., Am. BAr Ass'n \& AM. ARbitration Ass'N, Code of Ethics For Arbitrators IN COMMERCIAL DISPUTES (2004), available at http://www.americanbar.org/content/dam/aba/ migrated/dispute/commercial_disputes.authcheckdam.pdf. 
Principles for ADR Provider Organizations, the leading community guideposts on provider ethics, embrace such steps and call for organizations "to help ensure that neutrals affiliated with the ADR Provider Organization are familiar with and conduct themselves according to prevailing norms of ethical conduct in ADR." ${ }^{\text {,33 }}$ The Principles also admonish providers to "conduct themselves with integrity and even-handedness in the management of their own disputes, finances, and other administrative matters." ${ }^{394}$ To this end, the Principles endorse the concept of organizational ethics standards, ${ }^{395}$ such as those adopted by some providers. ${ }^{396}$

The Principles also call for providers to create mechanisms for addressing grievances about the organization or individual arbitrators or mediators, "disclos[ing] the nature and availability of the mechanisms to the parties in a clear, accurate and understandable manner."397 Such mechanisms would be "concerned primarily with complaints about the conduct of the neutral, or deficiencies in process and procedures" ${ }^{\text {"398 }}$ but would not serve the role of an appeals process. ${ }^{399}$

\section{E. Fair Hearing}

The first abiding principle of the Consumer Due Process Protocol states that "[a]ll parties are entitled to a fundamentally-fair ADR process. As embodiments of fundamental fairness, these Principles should be observed in structuring ADR Programs." 400 Several elements of fairness may be discerned from the Protocols and other leading exemplars.

\footnotetext{
393. See PRINCIPLES FOR PROVIDER ORgANIZATIONS, supra note 43 and text accompanying note 273.

394. PRinCiPLes for PROVIDER ORganizations, supra note 43, Principle 7.

395. Id. The Principles explain:

ADR Provider Organizations should consider adopting ethical guidelines for employees or other individuals associated with the Organizations who provide ADR management or administrative services, addressing such issues as impartiality and fair treatment in ADR administration, privacy and confidentiality, and limitations on gifts and financial interests or relationships.

Id. Principle $7 \mathrm{cmt} .2$.

396. See supra note 275 and accompanying text (discussing AAA organizational ethics standards).

397. PRinciples for PRovider ORganizations, supra note 43, Principle 7.

398. Id. Principle $7 \mathrm{cmt}$. The mechanism would "also provide a fair and impartial process for the affected neutral or other individual against whom a grievance has been made.” Id. Principle 7.

399. See id. Principle $7 \mathrm{cmt}$. (stating that the mechanisms would not provide an appeals process to address the outcome of the ADR proceeding).

400. CONSUMER PRotocol, supra note 33, Principle 1.
} 


\section{Reasonable Costs and Fees}

Private justice, like public justice, entails real costs. In private systems unsupported by taxpayers, however, a larger portion of the transactional costs of justice are internalized. Requiring consumers to bear a significant portion of the administrative costs and fees associated with binding arbitration-amounts in excess of typical court fees-raises basic access-to-justice issues. ${ }^{401}$ Therefore, some measures are required to ensure that consumers are not forced to bear excessive costs, including subsidization of costs by the company that called for arbitration in its consumer contract. ${ }^{402}$

On the other hand, how a justice system is funded may affect perceptions regarding the fairness and independence of the system. If a company completely underwrites the cost of the consumer arbitration system in which it contests disputes with consumers, then the consumer might view the system as proprietary. Moreover, there is a potential that consumers might view arbitrators as somehow beholden to a party that shoulders the substantial burden of fees. ${ }^{403}$

401. See Schmitz, supra note 4, at 162-64 (noting that, for example, the AAA refuses to administer proceedings where arbitration clauses require consumers to pay all arbitration costs and fees).

402. The Consumer Due Process Protocol states:

In some cases, the need to ensure reasonable costs for the Consumer will require the Provider of goods or services to subsidize the costs of ADR which is mandated by the agreement. Indeed, many companies today deem it appropriate to pay most or all of the costs of ADR procedures for claims and disputes involving individual employees.

Consumer Protocol, supra note 33, Principle 6 (citation omitted) (citing Mei L. Bickner et al., Developments in Employment Arbitration, 52 DisP. RES. J. 8 (1997); Michael F. Altschul \& Elizabeth S. Stong, AAA Develops New Arbitration Rules to Resolve Wireless Disputes, ADR Currents, Fall 1997, at 6). The Consumer Due Process Protocol also states:

[I]t may [also] be possible to fulfill the principle of reasonable cost by the use of the Internet, the telephone, other electronic media, or through written submissions. Abbreviated procedures may be particularly appropriate in the context of small monetary claims, where there is always the alternative of a face-to-face hearing in small claims court.

Id.

403. The Consumer Due Process Protocol observes:

At the same time, there are legitimate concerns that having the Provider pay all or a substantial portion of neutral's fees and expenses may undermine the latter's impartiality. For this reason, as observed in the Employment Due Process Protocol, "[i]mpartiality is best assured by the parties sharing the fees and expenses of the mediator and arbitrator." Therefore, the Advisory Committee concludes that Consumers should have the option to share up to half of the Neutral's fees and expenses. In addition, unless the parties agree otherwise after a dispute arises, the handling of fee arrangements and the payment of fees should be conducted by the Independent ADR Institution. The latter, "by negotiating the 
Standards governing cost coverage often attempt to balance these concerns in some fashion. For example, although it is common for companies to subsidize fees and costs of arbitration so that consumers are not required to pay more than the equivalent of court fees, ${ }^{404}$ and fee waivers may also be permitted in appropriate cases, ${ }^{405}$ the Consumer Due Process Protocol states that consumers should have the option to pay more if they so desire. ${ }^{406}$ A rating system may reasonably take account of these concerns.

\section{Legal Counsel}

In some consumer arbitrations, a fair hearing might not be possible without the participation of counsel. Although the exemplars described in Part III do not call upon companies to defray consumers' attorneys' fees in arbitration, they do generally recognize the right of parties to be represented by individuals of their choice, including legal counsel. ${ }^{407}$

\section{Reasonable Hearing Location}

One must consider whether a party has the opportunity to attend the hearing when determining whether the hearing is fair. ${ }^{408}$ For this reason, some courts have held that provisions in mandatory arbitration agreements that require consumers or employees to travel unreasonable

parties' share of costs and collecting such fees, might be able to reduce the bias potential of disparate contributions by forwarding payment to the mediator and/or arbitrator without disclosing the parties' share therein.

Id. (citations omitted) (citing Employment Protocol, supra note 187, Principle 6; Stephen J. Ware, Arbitration and Unconscionability After Doctor's Assocs., Inc. v. Cassarotto, 31 WAKE FOREST L. REV. 1001, 1023 (1996)).

404. See id. (stating that many court-connected ADR programs are becoming subsidized).

405. See id. (stating that some ADR tribunals have employed mechanisms for waiving filing fees and administrative expenses).

406. The Consumer Due Process Protocol states:

Consumers should have the option to share up to half of the Neutral's fees and expenses. In addition, unless the parties agree otherwise after a dispute arises, the handling of fee arrangements and the payment of fees should be conducted by the Independent ADR Institution. The latter, "by negotiating the parties' share of costs and collecting such fees, might be able to reduce the bias potential of disparate contributions by forwarding payment to the mediator and/or arbitrator without disclosing the parties' share therein.”

Id. (citing EMPLOYMENT PROTOCOL, supra note 187, Principle 6).

407. See id. Principle 9 (stating that "[a]ll parties participating in processes in ADR Programs have the right, at their own expense, to be represented by a spokesperson of their own choosing”).

408. Id. Principle 7, Reporter's Comments. 
distances to a hearing are unenforceable. ${ }^{409}$ Moreover, arbitration fairness standards require a hearing's location to be reasonably close to the consumer. ${ }^{410}$ JAMS requires that a hearing be made available to the consumer "in his or her hometown area."411

\section{Access to Information and Discovery}

The role of discovery in arbitration is much debated, as it presents parties with something of a double-edged sword. On one hand, parties' access to information and the ability to conduct discovery is often necessary to achieving a fair and meaningful outcome. ${ }^{412}$ Without the appropriate facts being brought to light, arbitrators would be left with little upon which to make an informed and fair decision. ${ }^{413}$ This need for information, however, must be tempered by the costly nature of discovery. In the name of efficiency, arbitration has traditionally been a less formal process than litigation, with simplified discovery contributing to shorter cycle time and lower costs. ${ }^{414}$ Extensive, lengthy discovery can restore these burdens, potentially to the detriment of individual consumers. For that reason, fairness in handling discovery involves a balancing act.

Discovery can also be problematic because parties often do not share the same ability to gather and analyze information. A party may not be represented by counsel and unable or unwilling to conduct adequate discovery. Having a protocol in place that requires certain information to be shared and made available to both parties can be essential to ensuring a fair hearing. Such a protocol might include having an arbitrator

409. See, e.g., Kubis \& Perszyk Assocs., Inc. v. Sun Microsys., Inc., 680 A.2d 618, $624-29$ (N.J. 1996).

410. The Consumer Due Process Protocol requires that arbitration be held in a "reasonably convenient location” for both parties. CONSUMER Protocol, supra note 33, Principle 7 (emphasis omitted).

411. JAMS POLICY ON CONSUMER ARBitRATIONS, supra note 220.

412. The Consumer Due Process Protocol establishes that an inability to gather information should never stand in the way of a party receiving a fair hearing. CONSUMER PROTOCOL, supra note 33, Principle 13, Reporter's Comments.

413. The importance of access to information in reaching fair outcomes is highlighted in the JAMS Policy on Consumer Arbitrations, which requires that an arbitration clause allows for the discovery of "non-privileged information relevant to the dispute." JAMS POLICY ON CONSUMER ARBITRATIONS, supra note 220.

414. FTC STUDY, supra note 20, at 37. 
supervise the information exchange between parties to ensure that the process is being completed in a fair and even-handed manner. ${ }^{415}$

In certain cases, the use of an advisory group that can develop appropriate information exchange guidelines may also be helpful. ${ }^{416}$ For example, under FINRA procedures, templates have been established detailing exactly what documents parties must produce, given the particular matter at hand. ${ }^{417}$ Because securities cases tend to fall into various well-defined categories, such templates serve both efficiency and fairness.

In some cases it may be appropriate or necessary to permit depositions. In employment cases, for example, depositions play an important role in information gathering. ${ }^{418}$

\section{Limitations Period}

Pre-dispute arbitration clauses sometimes include terms prescribing how long after the alleged injury a party may file an arbitration claim. While limitations periods may create greater certainty by helping to protect against frivolous claims, unreasonably short limitations periods may diminish the ability of consumers to seek redress for legitimate claims. In order to prevent companies from establishing unreasonable limitations periods, which may attempt to take advantage of customers' general lack of knowledge about the need to take their claim to arbitration, some fairness standards provide that arbitration limitation periods should be no shorter than the statutory limitation period that would be available in court. ${ }^{419}$

415. The Consumer Due Process Protocol recommends that this arbitrator-supervised process be implemented in cases of mandated arbitration for consumer disputes. CONSUMER PROTOCOL, supra note 33, Principle 13. Arbitrators may also have the flexibility to require further discovery if deemed necessary later in the arbitration process. Id. Principle 13, Reporter's Comments. This flexibility allows for a more simplified discovery process up front, while recognizing the reality that some cases will require greater information exchange down the road. Id.

416. Id.

417. FINRA provides parties with a discovery guide and document production lists. See Customer CODE, supra note 246, at 39.

418. JAMS Employment Arbitration Minimum Standards of Procedural Fairness calls for discovery to include the "identification of witnesses" and "one deposition for each side," with additional discovery "at the arbitrator's discretion.” JAMS POLICY ON CONSUMER ARBITRATIONS, supra note 220, Standard No. 4 cmt.

419. Model Arbitration Act, § I.12 (Proposed Draft 2010) (Submitted by Lew Maltby) (on file with author). 


\section{Expeditious Process}

Unreasonable time delays can jeopardize the fairness of arbitration. ${ }^{420}$ Therefore, fairness may require that measures be put in place to ensure that arbitration is being carried out in an expeditious manner. Time limits or guidelines established by the arbitration provider may help avoid unnecessary delays at each step of the arbitration process. $^{421}$ They may also help protect against abuse of the system, wherein a party with greater money and resources might attempt to wear down the other with costly delay. As noted above, the speed and efficiency of the arbitration process is heavily dependent on the approach the parties and arbitrators take to discovery and information gathering. ${ }^{422}$

\section{Fair Hearing}

A "fundamentally fair hearing" should be provided to all parties who arbitrate. ${ }^{423}$ A fair hearing requires a transparent process free from bias or the appearance of bias. ${ }^{424}$ Hearings, therefore, must be conducted by fair and neutral arbitrators acting within the framework of an established protocol that creates the same level playing field for all. ${ }^{425}$ A fair hearing must also be categorized by sufficient notice and the opportunity for both parties to appear at the hearing. While these fundamental elements of fairness must be met, arbitration often allows parties flexibility in how hearings are conducted. ${ }^{426}$ This flexibility can be advantageous as long as standards of fairness and equal opportunity to be heard are upheld.

420. See generally The College of Commercial Arbitrators, Protocols for Expeditious, Cost-EFFEctive Commercial ARbitration 22-42 (Thomas J. Stipanowich et al. eds., 2010), available at http://www.thecca.net/CCA_Protocols.pdf (discussing and addressing concerns about excessive delay and cost in arbitration).

421. The Consumer Due Process Protocol calls for reasonable time limits for arbitration proceedings. CONSUMER PROTOCOL, supra note 33, Principle 8.

422. See supra Part IV.E.4 (noting the accessibility of services as a rubric for dispute resolution services); see also CONSUMER PROTOCOL, supra note 33, Principle 13, Reporter's Comments (discussing binding arbitration and its hallmark in avoiding the cost and delay in extensive prehearing discovery).

423. See MACNEIL, SPEIDEL \& STIPANOWICH, supra note 29, § 32.3.1.1.

424. FTC STUDY, supra note 20, at 46.

425. According to CPR-Georgetown Commission on Ethics and Standards of Practice in ADR, arbitration providers must take "all reasonable steps" available to ensure their services are impartial and fair. PRINCIPLES For PROVIDER ORganizations, supra note 43, Principle 3.

426. For example, online dispute resolution may be a suitable format for dispute resolution and satisfy the requirements of fairness, even though the parties do not meet in person to arbitrate. CONSUMER PROTOCOL, supra note 33, Principle 12, Reporter's Comments. 


\section{Availability of Class Action}

Class actions, while controversial, have historically been touted as a means for plaintiffs with small claims to join their interests together when, individually, their claims may have been too small. ${ }^{427}$ Class actions have also been seen as a way to deter companies from bad behavior by giving greater power to plaintiffs through collective action. ${ }^{428}$ Now, however, the option of class action is threatened by the ability of companies to contract around class actions through the use of class action waivers in pre-dispute arbitration clause. The availability of class action suits has become the central issue in the debate over binding arbitration provisions in contracts of adhesion. ${ }^{429}$ These pre-dispute clauses now frequently contain terms purporting to waive an individual's ability to participate in a class action. ${ }^{430}$ In fact, a company's desire to eliminate the possibility of class actions is now cited as the primary, if not the sole, motivating factor in including pre-dispute arbitration provisions in these contracts. ${ }^{431}$ The result of class action waiver provisions, as one commentator puts it, is that "consumer-plaintiff arbitrations ... essentially never occur." ${ }^{432}$

The recent Supreme Court ruling in AT\&T Mobility LLC $v$. Concepcion has raised new concerns as to what options consumers have in the face of such class action waivers. ${ }^{433}$ Concepcion upholds the enforceability of class action waivers in pre-dispute arbitration clauses, citing the supremacy of the FAA to limit these agreements under state unconscionability doctrine. ${ }^{434}$ To the extent it governs, Concepcion enables companies to avoid collective actions in both litigation and

\footnotetext{
427. See Stipanowich, supra note 2, at 336 n.72.

428. See id. (discussing opinions of opponents to class-action waivers).

429. See id. at 335-36.

430. See Schmitz, supra note 4, at 146, 148 (noting widespread use of class action waiver provisions in consumer credit card and wireless contracts).

431. See id. at 150 (“[C]ompanies use arbitration clauses to limit their vulnerability to consumer claims, especially class actions.”).

432. Developments in the Law, supra note 21, at 1172.

433. See 131 S. Ct. 1740 (2011).

434. See id. 1747-51 (2011) (discussing unconscionability and the FAA). The Court states that the policy behind the FAA is to enforce arbitration agreements as written. Id. at 1748. Justice Scalia's opinion focuses on advancing the pro-arbitration stance of the FAA, but it expresses little concern for how the FAA's principle of fundamental fairness will be met under these new restrictions. Stipanowich, supra note 2, at 382. Without the ability of the judiciary to police such agreements, fundamental fairness is jeopardized in the name of efficiency. Id. at 387.
} 
arbitration, ${ }^{435}$ requiring consumers to bring claims individually. How to make this process feasible for the average consumer with a low claim amount has yet to be determined. New developments in the realm of online dispute resolution may be able to help address such concerns; ${ }^{436}$ meanwhile, waiver provisions raise serious fairness issues. The ameliorative effect of customized provisions such as those in the AT\&T Mobility contract at issue in Concepcion is the subject of debate. ${ }^{437}$ It may be possible, however, for companies to develop new approaches that would to some extent counteract the impact of a class action waiver through incentives for individual action, thereby justifying a more favorable fairness rating on the Arbitration Fairness Index.

\section{F. Fair Outcomes (Awards and Remedies)}

\section{Access to Remedies Available in Court}

Another measure of fairness in the realm of arbitration is access to remedies. A major flashpoint of concern has been whether parties are entitled to receive punitive damages in arbitration. ${ }^{438}$ Today, however, the authority of arbitrators to address punitive damages claims is supported by court decisions ${ }^{439}$ as well as some statutes. ${ }^{440}$ In addition, the Protocols and rules of leading arbitration providers have attempted to ensure that parties are eligible to receive the same types of remedies in arbitration as those available in court. ${ }^{441}$ Under current FINRA arbitration procedures, for example, punitive awards are an important feature of the remedial landscape. ${ }^{442}$

\footnotetext{
435. Stipanowich, supra note 2, 388.

436. See supra Part III.G.

437. See Stipanowich, supra note 2, at 371-75 (summarizing judicial treatment of AT\&T Mobility's provisions).

438. See generally Thomas J. Stipanowich, Punitive Damages in Arbitration: Garrity v. Lyle Stuart, Inc. Reconsidered, 66 B.U. L. REV. 953 (1986) (discussing access to punitive damages in arbitration proceedings).

439. See MACNEIL, SPEIDEL \& STIPANOWICH, supra note 29, § 36.3.

440. See, e.g., REVISED UNIF. ARBITRATION ACt § 21(a) (2000) (allowing punitive damages).

441. JAMS Policy on Employment Arbitration Minimum Standards of Procedural Fairness requires that "all remedies that would be available... in a court proceeding ... must remain available in arbitration.” JAMS POLICY ON EMPLOYMENT ARBITRATION, supra note 198, Standard 1. The Consumer Due Process Protocol contains a similar provision. CONSUMER Protocol, supra note 33, Principle 14.

442. Choi \& Eisenberg, supra note 250, at 511 (noting that reforms to FINRA may "generate
} changes over time in punitive damages award rates"). 


\section{Publication of Reasoned Awards}

The publication of reasoned awards may promote greater fairness by enhancing the transparency of awards and, hopefully, causing arbitrators to exercise more care in reaching decisions. ${ }^{443}$ Providing parties with a "why" may also leave parties more satisfied with the process and accepting of the result. ${ }^{444}$ For these reasons, the Consumer Due Process Protocol contains a provision calling for a "brief written explanation of the basis for the [arbitral] award" upon the request of a party. ${ }^{445}$

\section{Outcomes}

When it comes to ranking arbitration programs, outcomes are a critical element. Indeed, the Berlin Principles admonish rating organizations to "[m]easure outcomes in preference to inputs wherever possible." ${ }^{446}$ As discussed above, a growing body of empirical research has explored a variety of relevant elements in arbitration, including consumer awareness and understanding of arbitration provisions, ${ }^{447}$ win/loss rates for employees or consumers, ${ }^{448}$ comparisons between outcomes in arbitration and court, ${ }^{449}$ and consumer perceptions of arbitration. ${ }^{450}$ In developing and implementing an Arbitration Fairness Index, such data are an essential complement to collecting information on published procedures and policies in arbitration programs.

443. CONSUmer PROtocol, supra note 33, Principle 15, Reporter's Comments.

444. Id.

445. Id. Principle 15. This requirement is also reflected in some commercial arbitration procedures. The CPR Rules for Non-Administered Arbitration of Business Disputes requiring a statement explaining the rationale for the award. INT'L INST. FOR CONFLICT PREVENTION \& RESOL., CPR Procedures \& Clauses: Non-ADMinistered ARBitration Rules, Rule 13.2, available at http://cpadr.org/Portals/O/Resources/ADR\%20Tools/Clauses\%20\&for\%2007\%20CPR\%20Rules\%2 0for\%20Non-Administered\%20Arbitration.pdf.

446. See supra text accompanying note 119 .

447. See, e.g., Schmitz, supra note 4, at 133-39 (surveying empirical arbitration research).

448. See, e.g., Drahozal \& Zyontz, supra note 351, at 845-46 (presenting results from the AAA's empirical study).

449. See supra notes 293-94 and accompanying text.

450. See generally Gross \& Black, supra note 295 (discussing consumer perceptions of securities arbitration clauses). 


\section{IMPLEMENTING AN ARBITRATION FAIRNESS INDEX}

Having considered factors that might be relevant and valid elements of a template for an Arbitration Fairness Index, we are faced with other questions relating to the implementation of an Index:

1. Can the Index be implemented in a cost-effective manner?

2. What kind of rating organization should implement the Index, and what should be the role of stakeholders and expert advisors?

3. How might relevant, accurate, and representative data be developed?

4. What formats might be used for publication of resulting ratings and rankings?

5. What role will the Index play alongside other sources of information about consumer and employment arbitration programs?

We will briefly address each of these subjects in turn.

\section{A. Cost-Effectiveness}

We have considered a number of public benefits likely to be engendered by an Arbitration Fairness Index-a rating system that ranks and compares arbitration programs associated with consumer and employment contracts. ${ }^{451}$ At the same time, there are legitimate questions about whether the costs of such a program would outweigh the benefits or whether a cost-effective method can be found for implementation of the program.

There are potentially significant fixed costs, depending on the breadth of the ratings program. There will be a need for infrastructure to obtain information on arbitration procedures, neutrals, and administration and actual operation. The cost of well-designed surveys or sampling of users' experiences or perceptions could also be substantial.

451. See supra Part II.B. 
Similarly, there are concerns on the demand side. It is not clear that consumers or their advocates would be willing to pay the cost of such guidance unless, for example, it could be presented in tandem with ratings of other products or services. The same may be true of information about a company's employment arbitration system without more general information about the company's workplace environment. To the extent that an effort is made to develop a "brand" of sufficient reputation to encourage demand, additional costs will be involved. ${ }^{452}$

There are reasons, however, to believe that these problems may be overcome. As discussed below, it may be possible for rating organizations with established infrastructures that focus more broadly on consumer, employee, or corporate social responsibility concerns to serve as vehicles for an arbitration rating system. ${ }^{453}$ Moreover, there appears to be significant and sustained interest among scholars and advocates regarding consumer and employment arbitration. An Arbitration Fairness Index may provide a focus, directly or indirectly, for their energy and scholarly activity, including relevant empirical research on outcomes, experiences, and perceptions. ${ }^{454}$ Finally, it may be possible for this effort to be significantly augmented by government agencies, notably the new Consumer Financial Protection Bureau (CFPB), which is authorized to develop information regarding the operation of arbitration for consumer financial services. ${ }^{455}$

452. See Furchtgott-Roth, Hahn \& Layne-Farrar, supra note 41, at 85.

453. See infra text accompanying notes 459-74.

454. See supra Part III.H. At the initial meeting of the National Roundtable on Consumer and Employment Dispute Resolution, held on the Pepperdine campus on Feb. 2-4, 2012, and cosponsored by Pepperdine School of Law, the Straus Institute for Dispute Resolution, and Penn State University Dickinson School of Law, significant interest was demonstrated among attending scholars, advocates, and others in the concept of an Arbitration Fairness Index. A working group was created to develop the concept further. See Nat'l Roundtable on Consumer \& Emp't Dispute Resolution, Consumer Arbitration Roundtable Summary Report, AM. BAR Ass'N (Apr. 17, 2012), http://www.consumerfinance.gov/pressreleases/consumer-financial-protection-bureau-launchespublic-inquiry-into-arbitration-clauses/.

455. The Consumer Financial Protection Bureau was established by the Dodd-Frank Wall Street Reform and Consumer Protection Act of 2010. See 12 U.S.C. § 5491 (2006 \& Supp. 2011). 


\section{B. Provenance and Control}

\section{Models for a Rating System}

Rating organizations depend upon their reputation for their success. $^{456}$ From the standpoint of stimulating corporate interest and influencing pertinent corporate behavior, the impact of any third-party rating system is likely to correlate directly with the degree of perceived power and legitimacy of the system. ${ }^{457}$ In order for the Arbitration Fairness Index to have meaningful impact on consumer awareness and corporate behavior, therefore, the standing and character of the sponsoring organization(s) is critical.

As previously noted, it may be feasible for a rating company or market research firm to sponsor development and implementation of the Index. While there are thousands of such firms in the United States, ${ }^{458}$ we will consider several highly visible organizations that might serve that role.

Consumer Reports, a leading source of information regarding products and services, is operated by the non-profit Consumers Union. ${ }^{459}$ Consumers Union's mission is to "work for a fair, just, and safe marketplace for all consumers and to empower consumers to protect themselves." 460 Consumer Reports National Research Center annually surveys a random sample of more than one million consumers regarding their experiences with purchased products. ${ }^{461}$ Consumers Union strongly emphasizes that its research program "is free of corporate influence and advertising" and that "surveys are not commissioned or financed by industry." "62 Like many consumer organizations, Consumers Union has adopted fairly strong views opposing the use of binding or mandatory

456. See, e.g., Furchtgott-Roth, Hahn \& Layne-Farrar, supra note 41, at 75 (discussing Nielsen Media Research Company’s interest in developing a reputation for sound ratings).

457. See Randel, Jaussi \& Standifird, supra note 75, at 441 (discussing stakeholder interests).

458. See Furchtgott-Roth, Hahn \& Layne-Farrar, supra note 41, at 63 (referring to U.S. Census Bureau statistics indicating there were 5,359 market research service providers in the United States in 2002 (citing U.S. Census Bureau, 2002 Economic CENSUS, Professional, SCIENTIFIC, AND TECHNICAL SERVICES 3 (Oct. 2004), available at http://www.census.gov/prod/ec02/ec0254i09.pdf)).

459. See About Consumers Union, CONSUMERS UNION, http://www.consumersunion.org/about/ (last visited Apr. 12, 2012).

460. Id.

461. How We Survey at Consumer Reports, CONSUMER REP., http:/www.consumerreports.org/ cro/consumer-reports-national-research-center/overview/index.htm (last visited Mar. 7, 2012).

462. Id. 
arbitration provisions in consumer and employment contracts ${ }^{463}$ and supports the passage of the as-yet-unpassed Arbitration Fairness Act. ${ }^{464}$ If such provisions continue to be enforceable under federal law, however, a publication such as Consumer Reports, with its supporting research infrastructure, might afford a particularly suitable platform for a consumer-oriented version of an Arbitration Fairness Index.

A more narrowly focused but much-publicized and increasingly preeminent rating program is the Corporate Social Responsibility Index (CSRI). The CSRI was jointly developed by an educational institution, the Boston College Center for Corporate Citizenship, and a for-profit international reputational management consulting company, the Reputation Institute. ${ }^{465}$ The CSRI purports to reflect how companies' reputations are affected by public perceptions of performance related to citizenship (the community and the environment), governance (ethics and transparency), and workplace practices. ${ }^{466}$ These three components are among seven elements of a larger annual reputational survey conducted yearly by the Reputation Institute. ${ }^{467}$ While the development and maintenance of consumer or employment versions of an Arbitration Fairness Index would be an undertaking well beyond the scope of the research protocol underlying the CSRI, the resulting data would certainly be relevant to one or more elements of corporate reputation measured by the Reputation Institute. ${ }^{468}$

\section{Importance of Broad-Based Input and Involvement}

No matter what organization sponsors the Index, its perceived viability will hinge on the quality of participation by those being rated,

463. See Press Release, Consumers Union, Groups Launch Nationwide Effort to Stop Use of Binding Mandatory Arbitration Clauses: Campaign Includes Educational Web Sites, Call for State and Federal Legislation, Tools to Empower Consumers (Feb. 24, 2005), available at http://www.consumersunion.org/pub/core_financial_services/002025.html.

464. See Letter from Numerous Companies to Honorable Patrick Leahy, Chairman, and Honorable Chuck Grassley, Ranking Member, U.S. Senate Committee on the Judiciary (May 17, 2011), available at http://www.afj.org/connect-with-the-issues/civil-justice/letter-in-support-ofarbitration-fairness-act_may-2011.pdf.

465. See supra text accompanying notes 79-81.

466. See supra text accompanying notes 81-83.

467. See supra text accompanying notes 79-83.

468. The fairness of a company's consumer arbitration program would seem to be directly relevant to the governance aspect, and the fairness of corporate dispute resolution procedures for employment disputes would be relevant to the workplace aspect. See infra text accompanying note 509 . 
those with relevant expertise, and other stakeholders. The Berlin Principles emphasize the importance of involvement by different stakeholder groups in rating systems, stating that "[i]nstitutions that are being ranked and the experts that inform the ranking process should be consulted often." 469 In addition, the Principles call for rating organizations to "be as objective and impartial as possible" in the collection and use of data. ${ }^{470}$

The makeup of the "rating constituency" is very important for a couple of reasons. First, it should be recognized that views of what standards and methods of measurement are appropriate are likely to be affected by one's position as a producer or consumer, seller or buyer, or employer or employee, and these differences in perspective should ideally be reflected in the deliberations leading to the development and implementation of the Index. ${ }^{471}$

In this regard, efforts to create broad-based, balanced advisory groups in connection with the development of due process protocols, ${ }^{472}$ and the evolution of policies and procedures for securities arbitration, ${ }^{473}$ offer general models. An Index advisory group would presumably include a carefully balanced aggregate of consumer and employee advocates, representatives of rated companies, and arbitration expertsincluding scholars with extensive and relevant empirical research experience. $^{474}$

\section{Role of Government}

Although it is appropriate to consider what, if any, role government agencies should play in conducting or supervising a rating program, the

469. See RANKING SYSTEMS, supra note 107, at 52.

470. Id. at 53.

471. See Furchtgott-Roth, Hahn \& Layne-Farrar, supra note 41, at 73-74 (discussing competing interests and political efforts between users and vendors in the TV ratings context).

472. See supra text accompanying note 371 (discussing advisory committee models).

473. See supra text accompanying notes 245-47 (discussing the National Arbitration and Mediation Committee).

474. There are also examples of custom-built, non-profit rating organizations with broad-based support and involvement. For example, in 1963 "[a] number of [television] industry players ... formed the Broadcast Rating Council Inc.," with membership including various media groups as well as major networks. Furchtgott-Roth, Hahn \& Layne-Farrar, supra note 41, at 69. These have been supplemented by cablecast companies, advertisers and ad agencies, and internet organizations. Id. The Rating Counsel was aimed at setting criteria and standards for ratings, ensuring that the ratings were "valid, reliable, effective, and viable" while accrediting ratings providers and ensuring their conformance to standards. Id. at 69-71. 
benefits of such an arrangement are not clear and an extensive treatment of this subject must be left for another time. Regulatory oversight of a private system would entail additional costs, and in some cases-such as a regulatory licensure or certification process for rating firms-might actually discourage entry into the "ratings market" by new firms. ${ }^{475}$

Although it is unlikely that there will be competition to produce and provide ratings of consumer and employment arbitration programs, ${ }^{476}$ there is evidence that in most sectors of the economy, rating services tend to be highly concentrated, with relatively few firms providing ratings. ${ }^{477}$ Rating services are generally not subject to regulation, and even in heavily regulated arenas like the workplace and environmental testing, rating methods are left to rating firms. ${ }^{478}$

On the other hand, agencies such as the CFPB may play an important part in obtaining case statistics and other information on arbitration programs that will be critical to meaningful development of an Arbitration Fairness Index. ${ }^{479}$

\section{Accuracy, Representativeness, and Utility of Data}

As previously noted, it is critical to have a rating system that reflects general agreement on what should be measured and what standards should be applied. ${ }^{480}$ Leading principles for rating systems state that rankings "should provide clarity about the range of information sources

475. Id. at 79-80 (discussing perceptions of the impact of SEC licensing of bond rating firms).

476. Cf. id. at 65-68 (noting potential for competition in the TV ratings industry and contrasting the ratings industry in foreign countries).

477. See id. at 83-87 (providing and explaining a chart of rating firms utilized in several different industries).

478. Id. at $86-87$.

479. The CFPB has authority to obtain information on arbitration programs. See Stipanowich, supra note 2, at 404-05. For example, the CFPB recently requested the following information about arbitration clauses from the public: "The prevalence of arbitration clauses in consumer financial products and services"; "What claims consumers bring in arbitration against financial services companies"; "If claims are brought by financial services companies against consumers in arbitration"; "How consumers and companies are affected by actual arbitrations"; and "How consumers and companies are affected by arbitration clauses outside of actual arbitrations." Press Release, Consumer Fin. Prot. Bureau, Consumer Financial Protection Bureau Launches Public Inquiry into Arbitration Clauses (Apr. 24, 2012), available at http://www.consumerfinance.gov/press releases/consumer-financial-protection-bureau-launches-public-inquiry-into-arbitration-clauses/. Critics of mandatory arbitration have expressed hope that this initiative will help address related concerns. Peter Andrew, Time to Fix the Arbitration System?, Fox Bus. (Jan. 25, 2012), http://www.foxbusiness.com/personal-finance/2012/01/24/time-to-fix-arbitration-system/.

480. See supra text accompanying note 129. 
for rankings" and that a variety of courses should be taken to obtain information "in order to get a more complete view."

Today, much negative publicity has been generated by the failure of rating systems to provide fair and accurate information. U.S. News \& World Report is roundly criticized for, among other things, overreliance on data provided by the rated institutions. ${ }^{482}$ Nielsen ratings have been targeted as unrepresentative samples ${ }^{483}$ that discriminate against minority TV viewers and use faulty sampling methods. ${ }^{484}$ The utility of the Arbitration Fairness Index will relate directly to the quality, accuracy, and representativeness of the information on which ratings are based.

\section{Published Information}

Much information on individual corporate arbitration programs is available in print or online. Pertinent contractual language, incorporated arbitration procedures, lists of potential arbitrators, and other relevant materials should be available from subject companies or the organizations providing arbitration services for the company. While these materials may be helpful in rating the fairness of a company's arbitration program, they do not provide a complete picture. In order to understand how the program actually operates, further investigation will be necessary. This may include interviews with company personnel or third parties responsible for maintaining helplines or administering dispute resolution processes. Ideally, it will also include statistics on the arbitration caseload and information on user experiences and perceptions.

\section{Case Statistics and Outcomes}

The Berlin Principles call for rating organizations to "[m]easure outcomes in preference to inputs whenever possible." ${ }^{485}$ It may be possible to acquire statistics on cases submitted to arbitration under the

481. See supra text accompanying note 115.

482. See, e.g., Martha Neil, US News Won't Recalibrate Law School Rankings Despite Word of More $U$ of Illinois Data Errors, ABAJOURNAL.com (Sept. 29, 2011, 6:12 PM), http://www.abajournal.com/news/article/us_news_wont_recalibrate_law_school_rankings/.

483. Furchtgott-Roth, Hahn \& Layne-Farrar, supra note 41, at 57-59 (discussing the complexities of obtaining representative sampling from Nielsen ratings).

484. Id. at 53 .

485. See RANKINGS SYSTEMS, supra note 107, at 4. 
contractual procedures; these may be available from the arbitration provider. ${ }^{486}$ In response to the disclosure requirements of the California Ethics Standards, for example, the AAA has posted a complete listing of all cases submitted to its administration under its various consumer arbitration rules and its Employment Dispute Resolution Rules. ${ }^{487}$ The AAA data compilation includes information on: (1) the identity of the business party; (2) the type of dispute; (3) the salary range of the individual party, if available; (4) the identity of the prevailing party; (5) an indication of whether or not the individual was represented by counsel; (6) the date on which the arbitration demand was filed; (7) the disposition date; (8) the type of disposition (settlement, award, etc.); (9) the amount claimed by the business; (10) the amount claimed by the individual party; (11) the total administrative fee paid to the AAA; (12) the fee amount allocated to and paid by each party; (13) the award amount for the business or individual; (14) other relief; (15) the AAA case ID number; (16) the identity of the arbitrator; and (17) the date on which the arbitrator was appointed. ${ }^{488}$ Similar information on consumer and employment cases is provided by JAMS, Inc; JAMS also includes the names of the parties' counsel, if any, and a tabulation of the number of cases JAMS has heard for either party. ${ }^{489}$

If possible, efforts should be made to ascertain the accuracy of such information. The Berlin Principles caution against overreliance on data that cannot be audited and verified. ${ }^{490}$

\section{Outcomes: Experiential and Perceptual Data}

Although considerable data relevant to an Arbitration Fairness Index may be derived from existing published materials and case statistics, a complete picture of an arbitration program cannot be obtained without data from individuals who have actual experiences with the arbitration program being rated.

One approach that might be employed is a broad-based consumer survey designed to assemble customer experiences and related

486. See Dispute Resolution Statistics, supra note 266.

487. See Consumer Arbitration Statistics, supra note 173. The AAA data are compiled on an extensive Excel spreadsheet. Although the format is unwieldy for casual users, it facilitates statistical research on the data.

488. See id.

489. See JAMS POLICY On CONSUMER ARBITRATIONS, supra note 220.

490. See RANKINGS SYSTEMS, supra note 107, at 53. 
perceptions. Surveys of this kind are conducted annually by the Consumer Reports National Research Center. ${ }^{491}$ Comprised of twenty trained social scientists, the Center surveys more than one million consumers each year regarding their experiences with various products and services using many different versions of the survey instrument tailored to different purposes. ${ }^{492}$

The National Research Center supplements consumer surveys with efforts to simulate the consumer experience with products. Staff "mystery shoppers" anonymously buy the products at retail outlets throughout the Northeast or online. ${ }^{493}$ The products are then subjected to

491. See How We Survey at Consumer Reports, supra note 461.

492. Id. Annual Questionnaires (AQ) are distributed to more than seven million Consumer Reports and ConsumerReports.org subscribers, in more than fifty different versions. Id. Consumer Reports receives responses from a random sample group of more than one million subscribers, who review many products and services, including about 1.3 million motor vehicles. Id.; Annual Questionnaire, CONSUMER REP. (last visited Mar. 7, 2012), http://www.consumerreports.org/ cro/consumer-reports-national-research-center/annual-questionnaire/index.htm. The AQ provides the data for Consumer Reports articles summarizing subscriber ratings of various kinds of service providers. See Annual Questionnaire, supra. These include "hotels, restaurants, supermarkets, chain restaurants, auto/home insurance, telecommunications, home improvement, electronics, and appliance retailers. ... Some recent reports include hospital visits, mental health experiences, and [r]atings of drugstore pharmacies.” Id.

Another relevant model is the Corporate Social Responsibility Index (CSRI), which uses broad annual surveys on consumer perceptions to rank the companies in the United States that the public distinguishes for corporate social responsibility. THE 2011 CSRI 50, supra note 69. Rankings are based on a 100-point scale. See Wilson, supra note 81. Two hundred eighty-five companies were measured in the 2011 [CSRI], of which "[ten companies] rated scores of [seventy-five] or higher to place them in the excellent category and another [fifty-seven] scored [seventy] or more to reach the strong category. Id. Among the top [fifty], every company scored 71.1 or higher." Id. The top ten companies were: Publix Super Markets Inc., Google, UPS, Kellogg's, Amazon.com, Berkshire Hathaway, FedEx, Campbell Soup Company, Baxter International, and 3M. THE 2011 CSRI 50, supra note 69. As discussed above, the CSRI ranking is determined by how the public perceives a company in three dimensions: citizenship, governance, and workplace. See id.

Rankings in the 2011 CSRI were “created using data collected for Reputation Institute's Global Pulse 2011, which was conducted in January 2011” through a survey of 7,790 online consumers in the United States. See Wilson, supra note 81.

A Pulse score is a measure of corporate reputation calculated by averaging perceptions of four indicators of trust, esteem, admiration and good feeling obtained from a representative sample of at least 100 respondents who were familiar with the company....

Each of the 7,790 respondents surveyed for the 2011 [CSRI] was allowed to rate a maximum of five companies with which they were familiar, resulting in a total of 24,977 ratings of 285 selected companies. All companies were rated by at least 100 respondents. Id. "Possible scores ranged from a low of 0 to a high of 100." Id.

493. See How We Test: Appliances \& Home Products, CONSUMER ReP., http://www.consumerreports.org/cro/how-we-test/home-appliances/overview/index.htm (last visited Mar. 7, 2012). 
"tests that re-create the experience [consumers will] have with the product." ${ }^{494}$ Testing takes into account relevant industry standards. ${ }^{495}$

Arbitration Fairness Index ratings should be based in part on the experiences of individuals who are subject to a company's consumer or employment arbitration agreements and who had relevant claims or disputes with the company. Surveys should assess, among other things, their level of awareness of the arbitration agreement and understanding of its consequences, ability to pursue and redress claims, and level of satisfaction with the dispute resolution process. If few or no claims are arbitrated under a contract, the reasons for that result should be clearly understood by the rating organization.

\section{Quality Assurance}

The Berlin Principles call upon rating programs to "apply measures of quality assurance to rankings processes."496 It has been said that ranking programs "should take note of the expertise that is being applied to evaluate [the rated] institutions and use this knowledge to evaluate the ranking itself." ${ }^{497}$ Furthermore, "[r]ankings should be learning systems that continuously apply this expertise to develop methodology." "498 To ensure the highest quality and a workable format for evaluation, it may be appropriate to conduct a pilot program at the outset. The rating organization should also consider the possibility of ranking a few representative programs each year or limiting rankings to one or two kinds of consumer contracts.

\section{Formats for Publication and Publicity}

The Berlin Principles suggest that consumers should be given a choice regarding the way rankings are displayed. ${ }^{499}$ The Consumers Union offers product ratings and information in several different formats including the Consumer Reports monthly magazine, a website (ConsumerReports.org), and ShopSmart monthly magazine. ${ }^{500}$

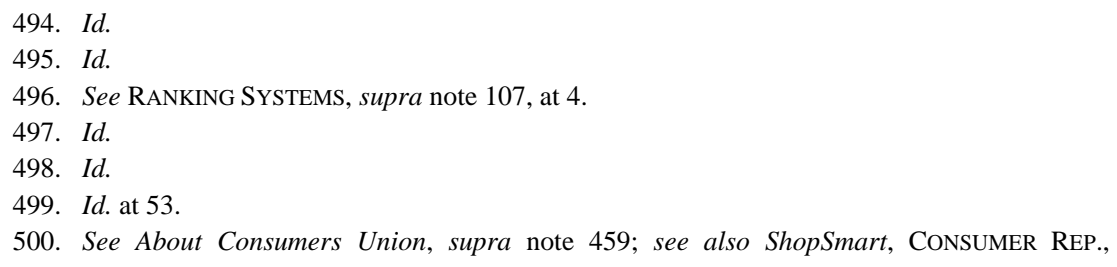


The CSRIs are publicized on the Center for Corporate Citizenship website. $^{501}$ In order to draw extra attention to the rankings, the Center gives special recognition to "The CSRI 50"-the top fifty U.S. corporations in the CSRI ratings. ${ }^{502}$ In addition, the CSRI also compares ratings from year-to-year in order to report significant improvement or decline of specific companies. ${ }^{503}$ It draws particular attention to "movers and shakers" - those companies that moved up more than five points in the CSRI rankings from one year to another. ${ }^{504}$ It also lists the twentyfive top-rated companies in each of the three "social responsibility dimensions" of workplace, governance, and citizenship. ${ }^{505}$ Finally, it graphically depicts the "linear relationship" between public perceptions of a company's social responsibility rating and their overall reputation as captured in the Global Reputation Pulse study. ${ }^{506}$

Arbitration Fairness Index rankings should be published annually and made broadly available in print-perhaps as a prominent element of a popular magazine aimed at consumers such as Consumer Reports—and online. The most highly ranked programs could be singled out for approbation, and the programs with the lowest scores could also be identified. A variety of explanatory devices could be used to highlight key differences between better and poorer arbitration programs and promote greater general public understanding of how different arbitration programs work. The publication of the rankings could be widely promoted online and on television.

\section{E. Rating System as Complementary to Other Sources of Information}

The Berlin Principles state that while "[r]ankings can provide comparative information and improved understanding" of rated programs, they should be viewed as complementary to other sources of information about the programs. ${ }^{507}$ Accordingly, the Arbitration Fairness

http://Shopsmartmag.org (last visited Apr. 12, 2012).

501. See Corporate Reputation and Social Responsibility Rankings, BOSTON COLL. CENTER FOR CORP. CITIZENSHIP, http://www.bcccc.net/index.cfm?pageId=2202 (last visited Mar. 7, 2012).

502. See id.

503. See id. (sharing reports from prior years).

504. See THE 2011 CSRI 50, supra note 69.

505. See, e.g., Boston Coll. Center FOR Corp. Citizenship \& Reputation Inst., The 2010 CORPORATE SOCIAL RESPONSIBILITY INDEX 3 (2010), available at http://www.bcccc.net/pdf/ CSRIReport2010.pdf.

506. See, e.g., id. at 6 .

507. See RANKING SYSTEMS, supra note 107, at 51-52. 
Index will be but one of numerous current initiatives by scholars, advocacy groups, provider organizations, and government agencies in the challenging realm of consumer and employment arbitration. Hopefully, however, it will provide a useful and unique resource for the edification and guidance of consumers, companies, providers of dispute resolution services, and regulators. If the Index proves its utility, moreover, it is conceivable that the garnering of a particular score on the Arbitration Fairness Index may someday operate as a "trustmark" for a corporate dispute resolution program. ${ }^{508}$

As a complementary standard, a viable Index may influence other ratings of businesses, including those of the Better Business Bureau and the CSRI. The latter, for example, rates companies on the basis of whether the business is "run in a fair and transparent fashion," whether "stakeholders [such as consumers] associate the company with high ethical business standards," and whether employees are treated fairly. ${ }^{509}$ The fairness of a corporation's consumer and employment dispute resolution programs are surely important factors in all of these determinations.

The Arbitration Fairness Index might also complement the work of the new $\mathrm{CFPB},{ }^{510}$ both benefitting from information developed under the auspices of the Bureau and contributing to the sum of knowledge respecting arbitration programs under contracts for consumer financial services.

One final, critical point should be made. As important as it is to examine and evaluate arbitration programs, a complete appreciation of their role in resolving consumer and employment disputes requires comparison to the usual "default option"-going to court. ${ }^{511}$ In some circumstances, as reflected in the recent Federal Trade Commission study of public and private resolution of debt collection cases, neither option is a truly satisfactory one. ${ }^{512}$

508. Cf. Amy J. Schmitz, "Drive-Thru” Arbitration in the Digital Age: Empowering Consumers Through Binding ODR, 62 BAYLOR L. REV. 178, 237-40 (2010) (discussing use of trustmark system to assure users of effective ODR).

509. See THE 2011 CSRI 50, supra note 69.

510. See supra text accompanying note 479.

511. See Stipanowich, supra note 2, at 423.

512. See FTC STUDY, supra note 20. 


\section{CONCLUSION}

If justice is to be administered as a private service, should it not be subject to monitoring, evaluation, grading, and ranking like other goods and services? Given the fact that binding arbitration serves as the adjudicative backdrop for consumer disputes or employer-employee conflict, the choice of arbitration and the kind of justice available under arbitration agreements may be every bit as important as consumer warranties and other substantive rights and remedies set forth in the contract. Yet consumers and employees tend to know very little about arbitration and how it affects their rights and obligations; corporate arbitration programs are an arcane and little-understood domain. Recent Supreme Court decisions have heightened concerns about the degree of effective judicial oversight of consumer and employment arbitration under binding pre-dispute agreements; efforts to address such concerns are largely stymied by a political logjam.

It is time to promote the development of an effective Arbitration Fairness Index that shines a light on these processes and enhances understanding and awareness of the use and impact of arbitration programs, among several other potential benefits. There are a number of very useful exemplars from which the elements of an Index may be constructed, and significant current interest and concern that may provide momentum for its creation and implementation. Although there are significant challenges associated with obtaining the several sources of information that will underpin program ratings, the result will be a unique and valuable resource that raises consciousness of arbitration programs to a new, more appropriate level. 